Hypercoagulability in cancer new aspects of Trousseau's syndrome 
(C) Marten Ronald Nijziel, Maastricht 2006

ISBN 10: 90-5278-571-6

ISBN 13: 978-90-5278-571-4

Layout: Tiny Wouters

Production: Datawyse | Universitaire Pers Maastricht

All rights reserved. No part of this thesis may be reproduced or transmitted in any form or by any means, without the permission in writing from the author. 


\title{
Hypercoagulability in cancer new aspects of Trousseau's syndrome
}

\author{
PROEFSCHRIFT \\ ter verkrijging van de graad van doctor \\ aan de Universiteit Maastricht, \\ op gezag van de Rector Magnificus, Prof. mr. G.P.M.F. Mols, \\ volgens het besluit van het College van Decanen, \\ in het openbaar te verdedigen \\ op vrijdag 3 november 2006 om 14.00 uur \\ door \\ Marten Ronald Nijziel
}

Geboren op 29 april 1965 te Amsterdam 
Promotor

Prof. dr. H.F.P. Hillen

\section{Copromotor}

Dr. K. Hamulyák

\section{Beoordelingscommissie}

Prof. dr. H. ten Cate (voorzitter)

Prof. dr. M.M. Levi, Academisch Medisch Centrum, Amsterdam

Prof. dr. M.H. Prins

Prof. dr. J. Rosing

Prof. dr. H.C. Schouten 
Uit: "Dichters" van Leo Vroman

\author{
Wie eerlijk schrijven \\ en ook publiceren \\ ontbloten hun lijven, \\ verbranden hun kleren \\ vertonen zich in het publiek \\ maar voelen langs nek en billen \\ altijd de wind van de kritiek \\ waar ze die wind niet willen.
}

Leo Vroman (1915) is hematoloog en schrijver 



\section{Contents}

$\begin{array}{ll}\text { Armand Trousseau (1801-1867) } & 9\end{array}$

Chapter 1 From Trousseau to angiogenesis: the link between the haemostatic system and cancer

Chapter 2 Goals, hypotheses and outline of the thesis

Chapter 3 Tissue factor activity in human monocytes is regulated by plasma: implications for the high and low responder phenomenon

Chapter 4 Increased D-dimer levels correlate with binding of activated protein $\mathrm{C}$, but not tissue factor expression, on peripheral blood monocytes in cancer patients

Chapter 5 Tissue factor activity in monocytes of cancer patients: evidence for the high and low responder phenomenon

Chapter 6 Acquired resistance to activated protein C in breast cancer patients

Chapter 7 The prognostic value of the soluble urokinase-type plasminogen activator receptor (s-uPAR) in plasma of breast cancer patients with and without metastatic disease

Chapter 8 Increased von Willebrand Factor levels and acquired resistance to activated protein $\mathrm{C}$ in breast cancer patients: implications after three and five years of follow-up

Chapter 9 General discussion, summary and conclusions

Samenvatting

Dankwoord

Curriculum vitae 



\section{Armand Trousseau (1801-1867)}

Professor Armand Trousseau was born in Tours in 1801. He did his training with the famous dr. Pierre Bretonneau and did pioneering work in a variety of diseases. He is known for Trousseau's sign in hypocalcemia and for Trousseau's spot in acute meningitis.

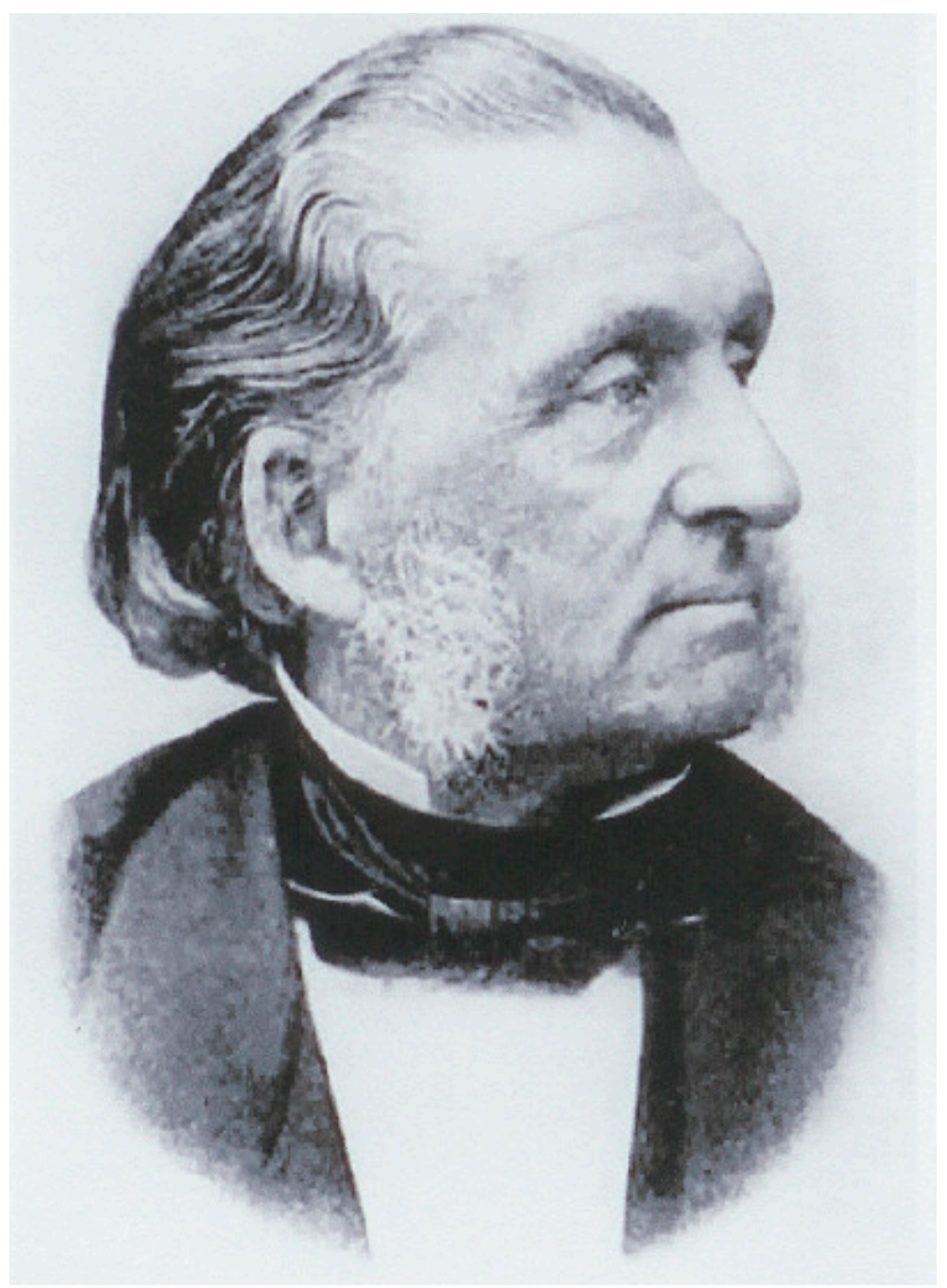




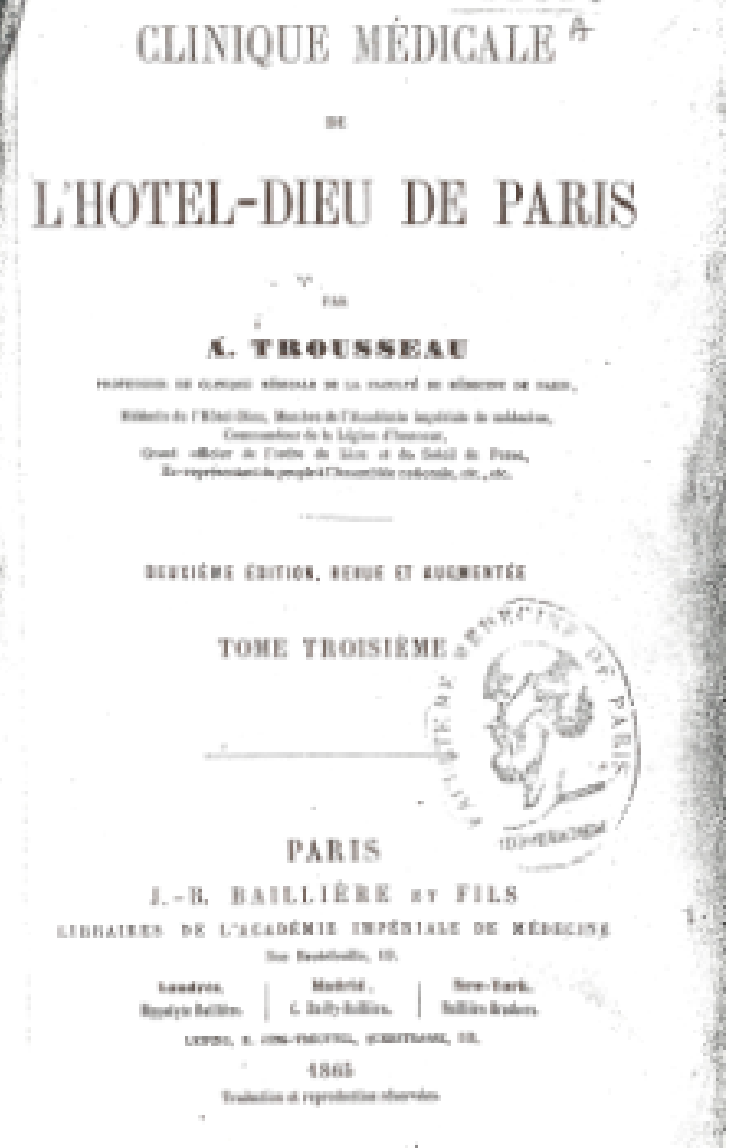

In 1850 he was appointed physician-in-chief at the Hôtel Dieu in Paris. In the 1850 s en 1860s he wrote a series of famous lectures later published as Clinique Médicale de l'Hôtel-Dieu. In one of these lectures in 1865 entitled Phlegmatia alba dolens he writes: "I have long been struck with the frequency with which cancerous patients are effected with painful edema in the superior or inferior extremities, whether one or other was the seat of cancer. This frequent concurrence of phlegmasia alba dolens with an appreciable cancerous tumor, led me to the inquiry whether a relationship of cause and effect did not exist between the two, and whether the phlegmasia was not the consequence of the cancerous cachexia. I have since that period had an opportunity of observing other cases of painful edema in which, at the autopsy, I found visceral cancer, but in which during life, there was no appreciable cancerous tumor". 


\title{
XCV. - PHLEGHATIA ALBA DOLENS.
}

\begin{abstract}
51. - Palngmatia dne femmet rocemnest actowehés. - Palegmalis des eachexiet

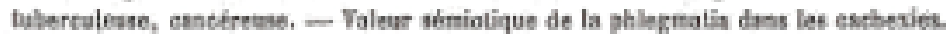

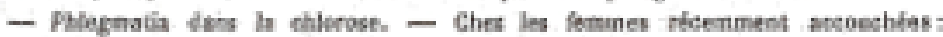

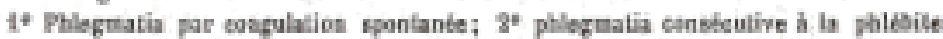
wiériut. - Symptimes de la phlegnatia : douleur, edtane. - Cordons veinteux. Cireulatioa collatitrele. - Temptrature des meabees affeties. - Point de lyophangile, point doudénite.
\end{abstract}

\section{Messieuks,}

Ceux d'eatre vous qui saivent mon service de clinique oat assortment remarqued la fréquence d'ane affection toute spleiale, biea digne d'appeler I'attention par la multiplicité des circonstaaces od elle s'observe, je veux parler de la palegmatia alba dolena. Voas vous rappelez que nous avoas étudit l'eedène blanc doulobreux, non-seulenébt chez les femmes récemment acconchles, mais plus souvent encore chez les malades des deux sexes affectes de phthisie pulmonsire on de tameurs canctreuses profoedes. Je veux, avjourd'hui, vous entretenir de cette affection, qui reconnait toujours poor cause première une alutration spécảle du sang. altération quí existe et dans l'ćtat puerperal et dass benucoup de cachexies. Je u'esayerai point d'tablir ici sur des relevés statistiques la fréquence relative de l'modzene douloureur dans les cachexies et dans l'état puerpéral; mon intention est seulement de vous firive remarguer que cette affection s'observe souvent, et que, en debors de lá poerpéralité, elle peot deveair dans les cachexies un précieux éltantat de diagnostic.

Il est des maladies qui réclameat une étude minutieuse, parte que le donte persiste sur la nature de Faffection, malger les fríguentes occasions que lion a de les therver. L'adime douloureax est du nombre de oes maladies od la nature et T'teiglogie sont diversement interprotéces. Je devrai done exposer Avec dérail les observations qui serviront de hase a la description gfotrale que jessagerai d'esuliser devant vous. Je devrai aussi vous rappeler atec soin les déeails anatomig̨uss, paree que os détails preadront ane graade valear quand il fudra fixer le siego précis de I'affection; d'aillears le silge une fois bien détermine, vous comprendrez mieux, l'anatomie aidant, la symptomatologie de la maladie et les complications si graves qui en soat quelquefois h conafquence.

Salle Saiat-Beraard, a* 5, est entrbe uae femme de trente-trois ans, pré-

This was the first published report of the association between cancer and thrombosis. Trousseau was even more ahead of his time by writing: "We must not suppose that painful edema of the inferior extremities in cases of cancer of the testicle, uterus or rectum results from the inflammation of the veins of the primary diseased parts being propagated to the deep-seated veins; nor are we to believe that the edema is the mechanical consequence of pressure exerted 
on the abdominal veins by tumors or diseased glands. Such opinions are untenable for whoever carefully analyses cases will find that cancerous tumors of the stomach or breast give rise to this kind of phlegmasia". Trousseau was the first to suggest a "modification of the blood" in cancer patients.

In January 1867 he noticed a phlebitis of his own upper left extremity. Several months later Armand Trousseau died of gastric cancer. His name will be linked forever to the intriguing field of thrombosis and malignancy. The migratory thrombophlebitis as seen in visceral cancer will be forever known as Trousseau's syndrome.

\section{References}

Khorana AA. Malignancy, thrombosis and Trousseau: the case for an eponym. J Thromb Haemost 2003; 1:2463-2465.

Trousseau A. Phlegmatia alba dolens. Clinique Médicale de l'Hôtel-Dieu de Paris. London: J.-B. Baillière et Fils 1865; tome troisieme: 654-712. 


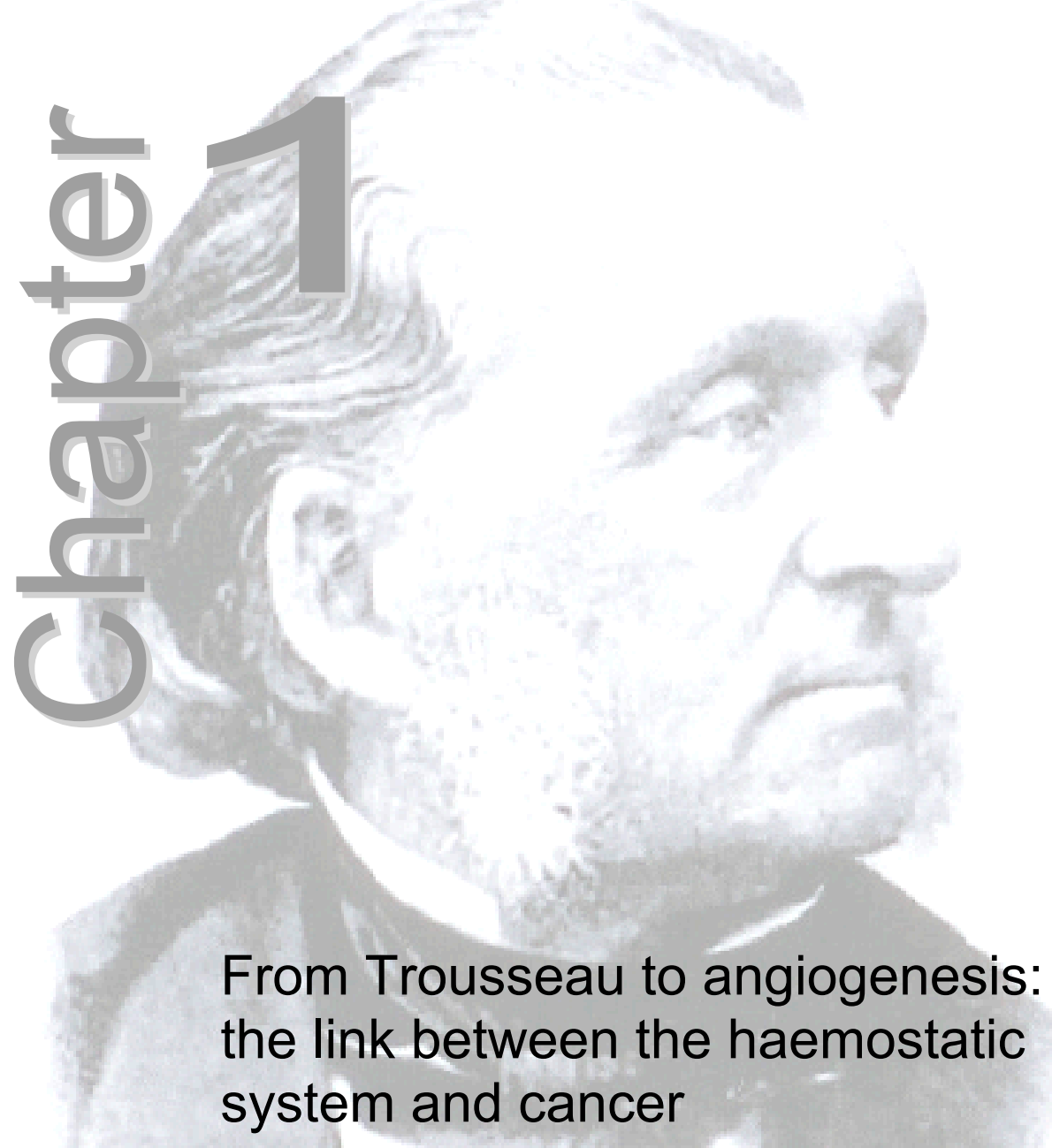

Marten R Nijziel, René van Oerle, Harry FP Hillen, Karly Hamulyák Neth $\mathrm{J}$ Med, in press 


\section{Introduction}

Thrombosis is one of the major complications of cancer. In $10-15 \%$ of the patients with clinically overt cancer spontaneous venous thrombosis, thromboembolism after cancer surgery, thromboembolism during chemotherapy and thrombosis of central venous access lines occur as clinical manifestations of thrombosis ${ }^{1}$. The relationship between cancer and thrombosis is also obvious by the clinical observation that thrombosis may be a presenting symptom of cancer. $10-20 \%$ of all non-cancer patients presenting with an idiopathic thromboembolism appear to have cancer within the next three years ${ }^{2}$. It was Armand Trousseau who in the $19^{\text {th }}$ century first noted "the alteration of the blood" in cancer patients ${ }^{3}$.

Moreover, there is now considerable evidence that the blood coagulation system is not only involved in cancer associated thrombosis, but also plays an important role in the biology of malignant tumors. Cancer cells interact with the coagulation system for their growth, for angiogenesis and for the dissemination through the body. Many components of the coagulation system are involved in tumor neovascularization and fibrin present in the matrix around tumor cells facilitates tumor cell growth ${ }^{4}$. The interference of tumor cells with the coagulation system leads to an increased activation of several coagulation pathways. And it is this hypercoagulability state that is the major determinant of the increased risk for the above-mentioned thromboembolic complications in cancer patients.

\section{Activation of the primary haemostatic system: platelets and von Willebrand Factor}

In normal primary haemostasis a vascular lesion is closed by the formation of a platelet plug. First, the platelets adhere transiently to subendothelial von Willebrand Factor (VWF) through the GPIb receptor. This adherence significantly slows the movement of the platelets. Second, the slowly moving platelets start to roll across the subendothelium and adhere to vWF and collagen through the GPIb and platelet collagen receptors. Finally, these interactions lead to platelet activation and aggregation through the GPIIb/IIla receptors on platelets, thereby stably adhering to the damaged vessel wall (Figure 1.1a). Hence, vWF plays an essential role by promoting the adhesion of platelets to the subendothelium. 


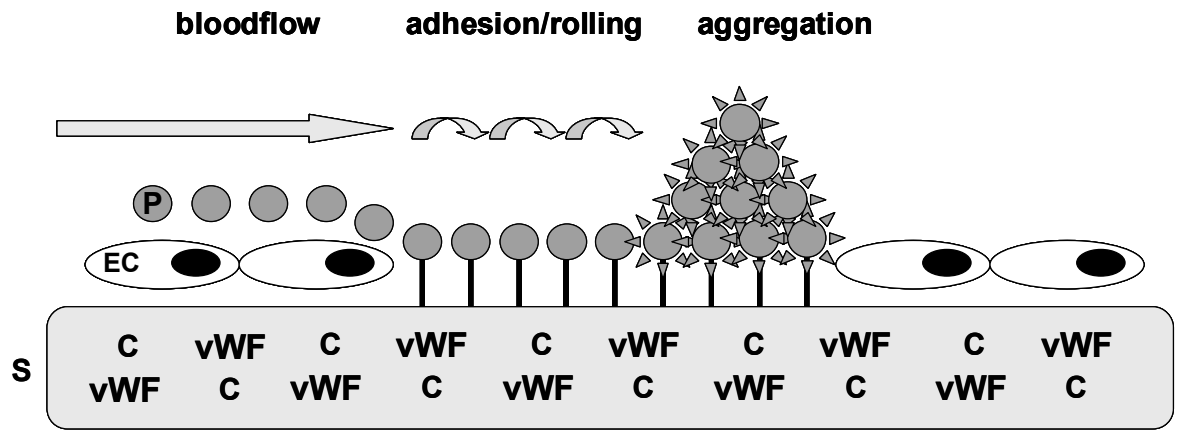

Figure 1.1a The primary haemostatic system ( $s=$ subendothelium; ec=endothelial cell; $p=p l a t e l e t ;$ $\mathrm{c}=$ collagen; $\mathrm{VWF}=$ von Willebrand Factor): circulating platelets adhere to the subendothelial VWF and collagen, leading to rolling, adhesion and aggregation.
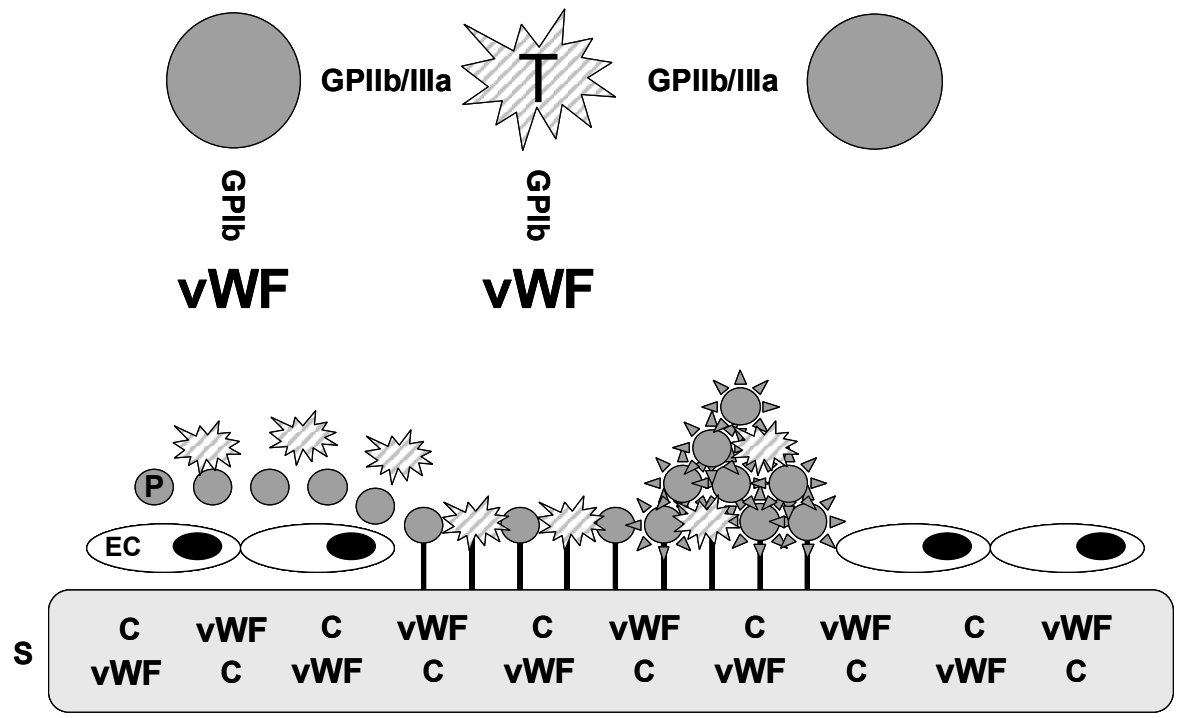

Figure 1.1b Involvement of tumor cells in the primary haemostatic system (s=subendothelium; ec=endothelial cell; $p=$ platelet; $c=$ collagen; $v W F=v o n$ Willebrand Factor; $G P=g l y c o-$ protein; T=tumor cell): circulating platelets and tumor cells adhere to the subendothelial VWF and collagen, leading to rolling, adhesion and aggregation through the GPIb and GPIIb/IIla receptors on platelets as well as tumor cells. 
In cancer patients both platelets and VWF are involved in cancer growth and dissemination ${ }^{5}$. It has been shown that platelets release vascular endothelial growth factor (VEGF), the important regulator of tumor-induced angiogenesis, ${ }^{5,6}$. Moreover, VEGF-stimulated endothelial cells promote adhesion and activation of platelets ${ }^{7}$. Previous animal studies showed that thrombocytopenia decreases and platelet transfusion stimulates tumor metastasis $^{8}$. Tumor cell adhesion to platelets might be essential for dissemination. Blocking tumor-binding receptors on platelets inhibits metastasis in vitro and in vivo ${ }^{9}$. Platelets adhering to tumor cells prolong tumor cell survival in mice by protecting them from lysis by natural killer cells ${ }^{10}$. It is suggested that by binding to activated platelets, tumor cells are able to adhere better to the endothelium (Figure 1.1b). Moreover, they secrete cytokines increasing the permeability of the vessel wall, thereby enabling dissemination in the surrounding tissue ${ }^{9,11}$.

Elevated vWF levels have been reported in various cancers in humans, among others breast cancer and colorectal cancer ${ }^{12-15}$. In the latter it has been shown that VWF levels are associated with tumor stage and metastases ${ }^{15}$. Experimental models in vitro and in vivo suggest that vWF facilitates binding of platelets to tumor cells thereby hiding the tumor cells from the immune system and enabling the attachment of tumor cells to the endothelium ${ }^{9}$. It has been demonstrated that tumor cells express the GPIb and the GPIIb/IIla receptor ${ }^{16}$. These receptors can bind the tumor cell to VWF and to platelets (Figure 1.1b). Patients with disseminated cancer also have a significant increase in unusually large vWF multimers which facilitate further binding to tumor cells. This presence of unusual large VWF multimers is the result of a local acquired deficiency of VWF cleaving protease (ADAMTS 13) ${ }^{17}$.

In conclusion, there is cumulating evidence for an important role of platelets and VWF in tumor growth and -dissemination.

\section{Activation of the secondary haemostatic system: a leading role for tissue factor}

In normal secondary haemostasis a fibrin clot is formed at the site of a vascular lesion by activation of a coagulation pathway starting with the exposition of subendothelial tissue factor (TF) eventually leading to the conversion of fibrinogen to fibrin. This TF has also been attributed to playing a pivotal role in the cancer-induced hypercoagulability.

TF is the key initiator of the coagulation cascade ${ }^{18}$. TF is a $47-k D a$ glycoprotein with a large extracellular domain. In the first or initiation phase TF activates coagulation by binding factor VII and factor VIla to the extracellular domain. 
The formed TF/factor VIla complex directly activates coagulation factor $\mathrm{X}$ to $\mathrm{Xa}$. Factor $\mathrm{Xa}$ is, together with factor $\mathrm{Va}$, responsible for the conversion of prothrombin to thrombin (i.e. factor II to Ila). Thrombin induces clot formation by inducing the conversion of fibrinogen to fibrin (Figure 1.2a).

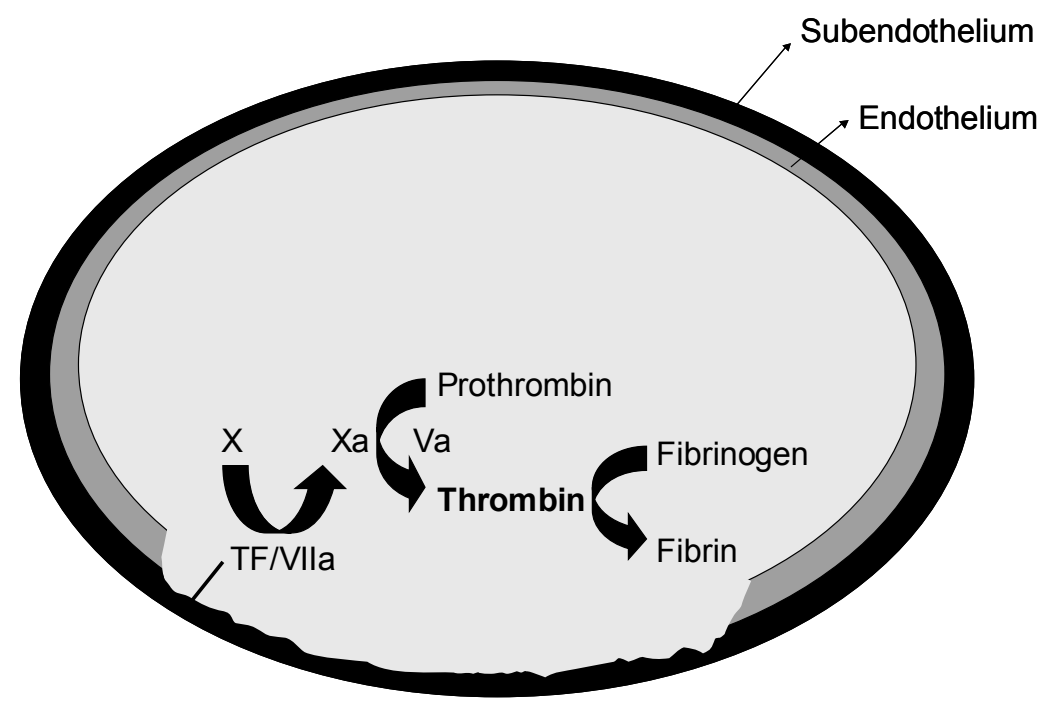

Figure 1.2a The initiation phase of the secondary haemostatic system. Roman figures denote coagulation factors, a=activated.

In addition to directly activating factor $X$, in the next or propagation phase the TF/factor VIla complex also indirectly activates factor $X$ to $X a$ by activating coagulation factor IX to IXa which, together with factor VIIla, also activates factor $X$ to $X a$. Again this leads to the conversion of prothrombin to thrombin and fibrinogen to fibrin (Figure 1.2b). Thrombin induces clot formation not only by inducing the conversion of fibrinogen to fibrin but also by directly activating platelets and by stimulating its own formation by activating clotting factors $\mathrm{V}$, VIII and XI (Figure 1.2b). Negatively charged phospholipids (the platelet membrane) and calcium are essential in the whole process of fibrin formation. TF is normally only localized in extravascular tissues not directly in contact with the blood stream. In case of a vascular lesion the subendothelial TF will be exposed to the blood resulting in platelet activation, fibrin formation and closing of the lesion. In cancer patients however, TF is expressed aberrantly on endothelial cells, monocytes and, most importantly, on tumor cells (Figure 1.2c). Moreover, cancer cells may produce a cysteine proteinase, named cancer procoagulant $(\mathrm{CP})$, which directly activates coagulation factor $\mathrm{X}$ to $\mathrm{Xa}{ }^{19}$. 


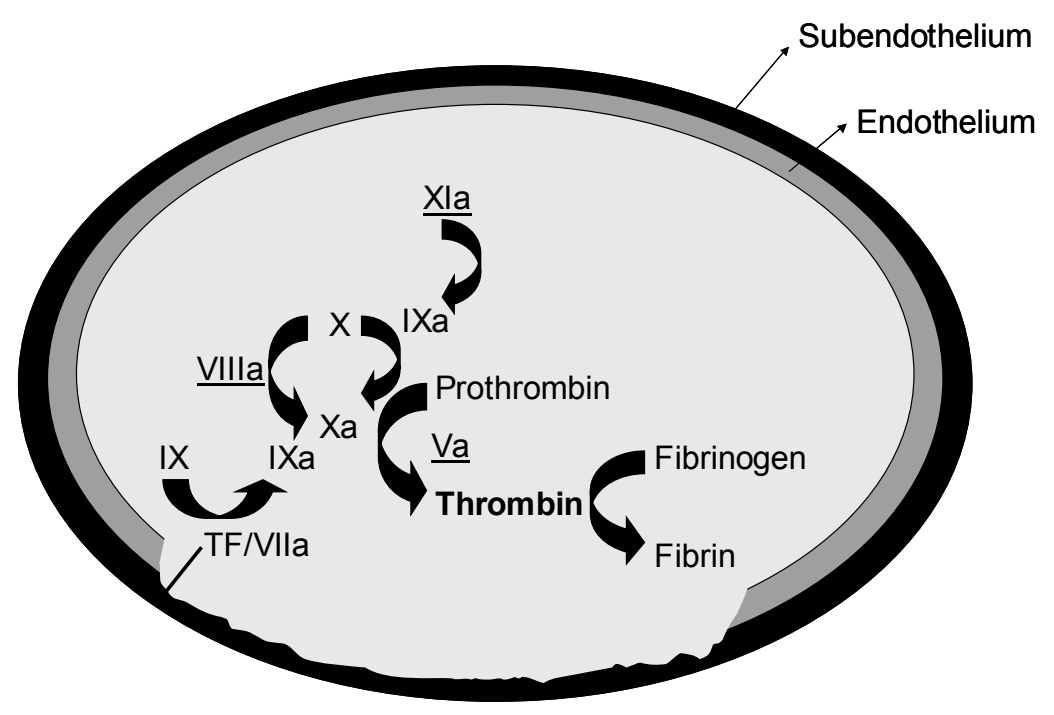

Figure 1.2b The propagation phase of the secondary haemostatic system. Roman figures denote coagulation factors, a=activated.

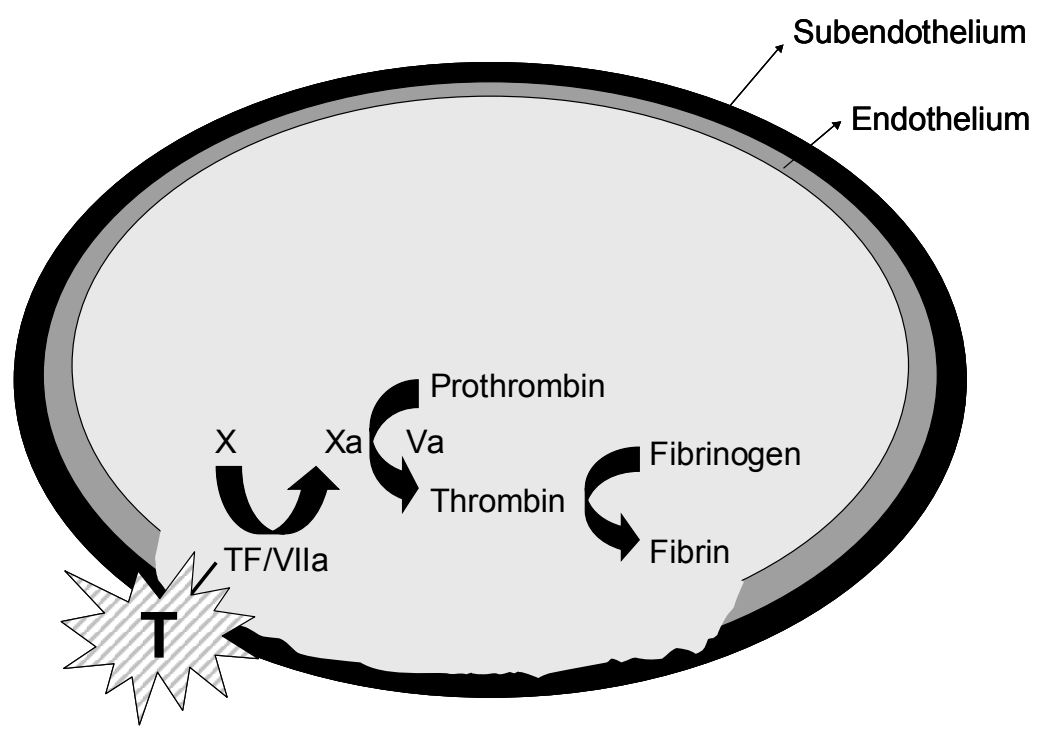

Figure 1.2c Involvement of tumor cells in the secondary haemostatic system. $\mathrm{T}=$ tumor cell. 
Endothelial cells do not normally express TF. The presence of TF on endothelial cells is induced by cytokines as TNF- $\alpha$ and IL-1 $\beta$ produced by tumor cells ${ }^{20}$. Moreover, these tumor cytokines induce expression of adhesion molecules on endothelial cells, making them capable of attaching other tumor cells $^{21}$. This accumulation of tumor cells leads to increased cytokine production and thereby increased TF expression on the endothelial cells. It is suggested that this is a major contribution to the cancer-induced hypercoagulability.

Monocytes also do not normally express TF. They express TF when activated by stimulating agents such as bacterial endotoxins, inflammatory cytokines and complement factors. TF on monocytes has been demonstrated in cancer patients mainly in studies in vitro. Isolated monocytes obtained from cancer patients expressed more tissue factor than monocytes from healthy controls $^{22-24}$. No studies have been performed measuring the TF expression on monocytes directly in vivo. However, TF expression on monocytes is still thought to play a major role in cancer-induced hypercoagulability ${ }^{25}$.

TF expression on tumor cells has been shown in many cancers, as breast cancer, lung cancer, colorectal cancer and pancreatic cancer. Elevated levels of tissue factor on tumor cells have been correlated with increased angiogenesis, increased vascular density, unfavorable prognosis and advanced disease ${ }^{26-29}$. TF on tumor cells is considered another important factor in the cancer-induced hypercoagulability and plays a pivotal role in angiogenesis. In preclinical studies TF-deficient mice died after ten days of embryonic development because of abnormal formation of yolk-sac vessels, suggesting a role of TF in physiologic angiogenesis ${ }^{30}$. The same applies to VEGF deficient mice, suggesting that TF and VEGF regulate similar functions ${ }^{31}$. Expression of TF in tumors upregulates the expression of VEGF, thereby inducing a switch to a more angiogenic phenotype and inducing sprouting of new blood vessels from pre-existing vessels ${ }^{32}$. Tumor cells overexpressing TF grew more rapidly and formed a larger and more vascularized tumor than TF underexpressing tumor cells ${ }^{31}$.

In conclusion, TF plays a central role in the activation of the coagulation system in cancer related thrombosis and in the enhancement of angiogenesis, tumor growth and tumor metastasis.

\section{Changes in the anticoagulant systems: TFPI, antithrombin and activated protein C}

In normal haemostasis there is a terminating system to prevent ongoing clotting and to confine the fibrin clot to the site of the vascular lesion. Key players in this system are tissue factor pathway inhibitor (TFPI), antithrombin (AT) and activated protein $\mathrm{C}$. TFPI, synthesized in the vascular endothelium, is the 
natural inhibitor of TF. It binds to the TF/factor VIla complex and binds directly to factor $\mathrm{Xa}$, thereby terminating the initiation phase of the coagulation cascade $^{33}$ (Figure 1.3a).

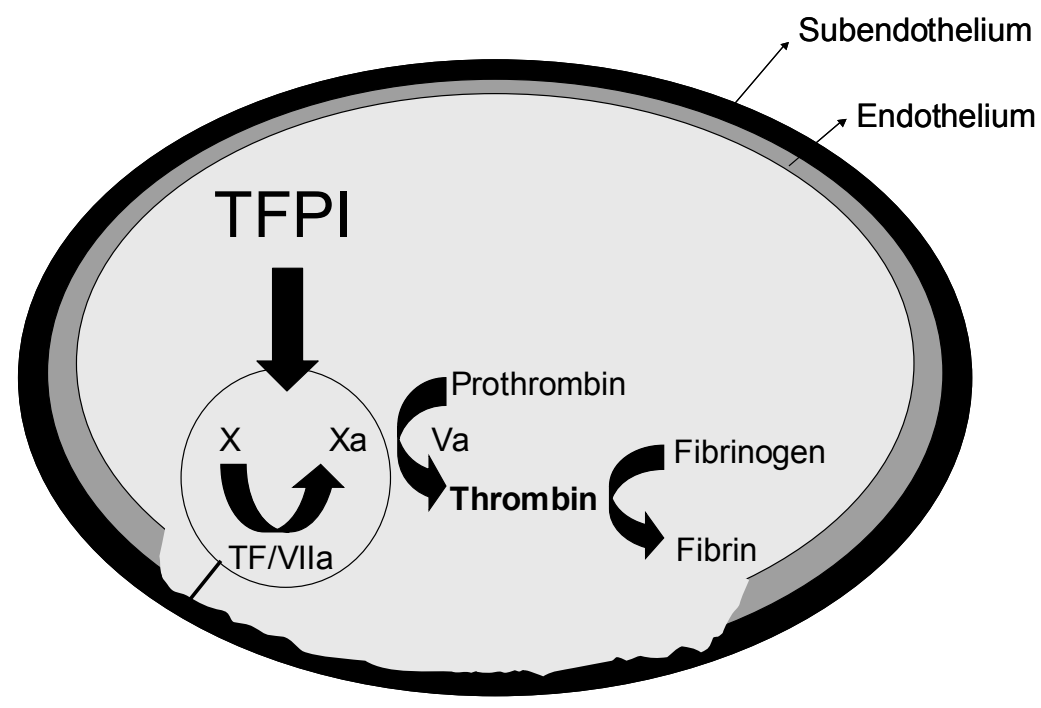

Figure 1.3a The termination phase of the secondary haemostatic system, action of tissue factor pathway inhibitor. TFPI=tissue factor pathway inhibitor. Roman figures denote coagulation factors, a=activated.

Antithrombin is the (slow) inhibitor of coagulation factors IXa, Xa and thrombin, thereby terminating the propagation phase (Figure 1.3b). Its effect can be greatly accelerated by heparins ${ }^{34}$.

Activated protein $C$ (APC), together with its cofactor protein $S$, inhibits the activity of coagulation factors VIIla and $\mathrm{Va}$, contributing to the termination of the propagation phase (Figure 1.3c). Vitamin K-dependent protein $\mathrm{C}$ is activated to APC on the surface of endothelial cells by thrombin bound to the membrane glycoprotein thrombomodulin. The endothelial protein $C$ receptor (EPCR) further stimulates the protein $\mathrm{C}$ activation ${ }^{35}$. 


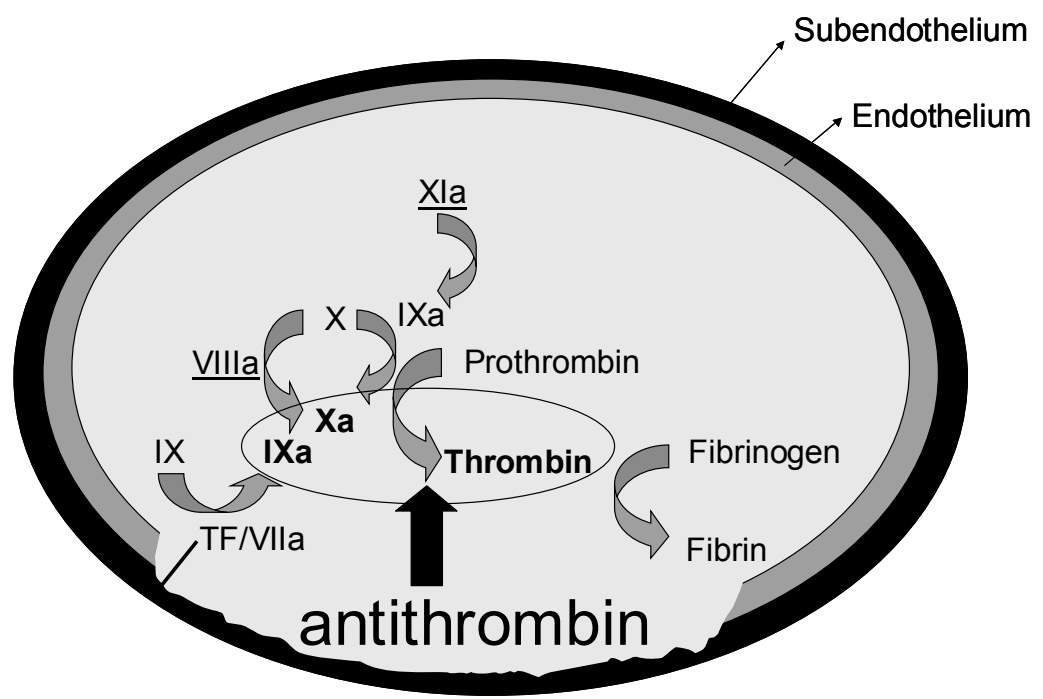

Figure 1.3b The termination phase of the secondary haemostatic system, action of antithrombin.

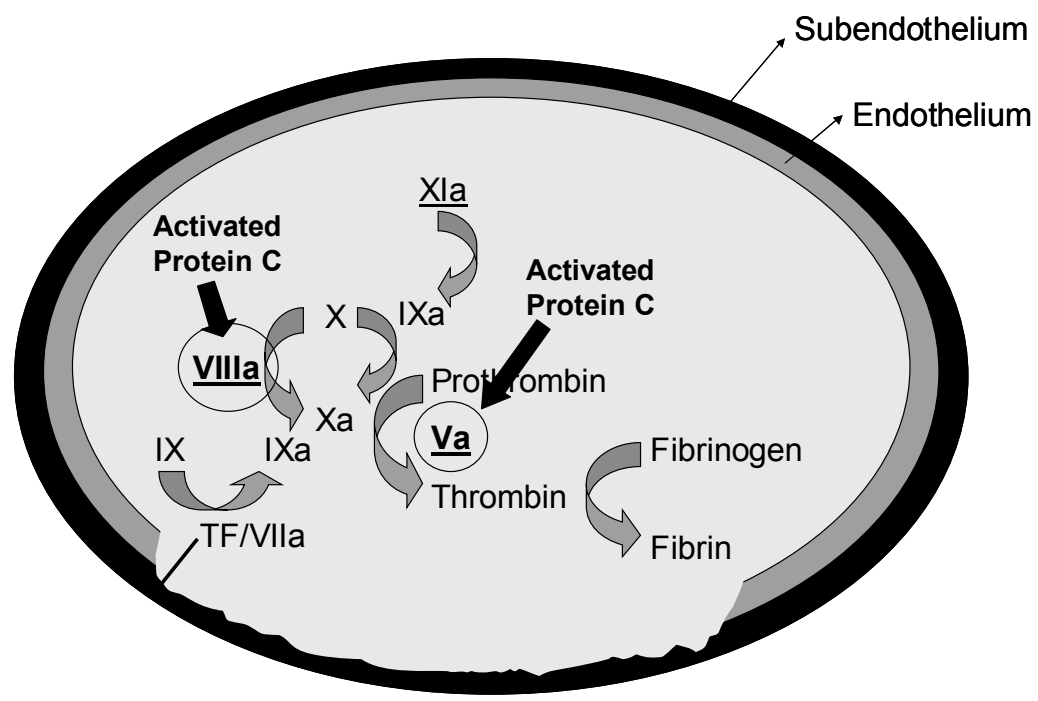

Figure 1.3c The termination phase of the secondary haemostatic system, action of activated protein C. 
Decreased activation of the anticoagulant factors TFPI, antithrombin and the proteins of the protein $\mathrm{C}$ pathway could lead to activation of haemostasis in cancer patients. Indeed, decreased levels of antithrombin and protein $C$ have been reported ${ }^{36}$. Moreover, there are strong indications that cancer patients without the factor $\mathrm{V}$ Leiden mutation have an acquired APC resistance ${ }^{37-39}$. However, also elevated plasma levels of TFPI have been demonstrated in patients with solid tumors ${ }^{40,41}$. TFPI-1 is the main inhibitor of TF, factor VIla and factor $\mathrm{Xa}$ and directly binds cancer cells to the extracellular matrix, thereby promoting cancer cell migration ${ }^{42}$. TFPI-2 has a low inhibitory activity to TF, factor VIla and factor Xa, but is a potent inhibitor of plasmin. Plasmin is a protease able to degrade the extracellular matrix directly or indirectly by activating matrix metalloproteinases. These matrix metalloproteinases degrade collagen and other matrix proteins, thereby allowing tumor cells and monocytes to invade the extracellular matrix and the surrounding tissues ${ }^{43}$. TFPI-2 inhibits the plasmin-mediated activation of matrix metalloproteinases involved in tumor progression, invasion, and metastasis ${ }^{44}$. Thus, elevated levels of TFPI-1 stimulate and elevated levels of TFPI-2 inhibit growth and dissemination of cancer cells.

In conclusion, there is cumulating evidence for an important role of anticoagulant proteins in cancer biology.

\section{Activation of the fibrinolytic systems: plasmin and its activators}

The fibrin formed in the initiation and the propagation phase of the secondary haemostatic system is strengthened by thrombin-activated factor XIII, catalyzing the formation of cross-links between adjacent fibrin chains to yield the mature clot $^{45}$. The fibrinolytic system is responsible for the lysis of these fibrin clots. In normal fibrinolysis plasminogen is converted to plasmin by activation of tissue plasminogen activator (tPA) or urokinase plasminogen activator (UPA). Plasmin cleaves the fibrin network and releases fibrin degradation products fragment $\mathrm{D}$, fragment $\mathrm{E}$ and $\mathrm{D}$-dimer (Figure 1.4a). Plasmin is inactivated by alpha-2-antiplasmin with the formation of plasminalpha-2-antiplasmin (PAP) complexes. The activity of tPA and UPA is inhibited by specific inhibitors, plasminogen activator inhibitor (PAI) 1 and 2 (Figure $1.4 b)$. 


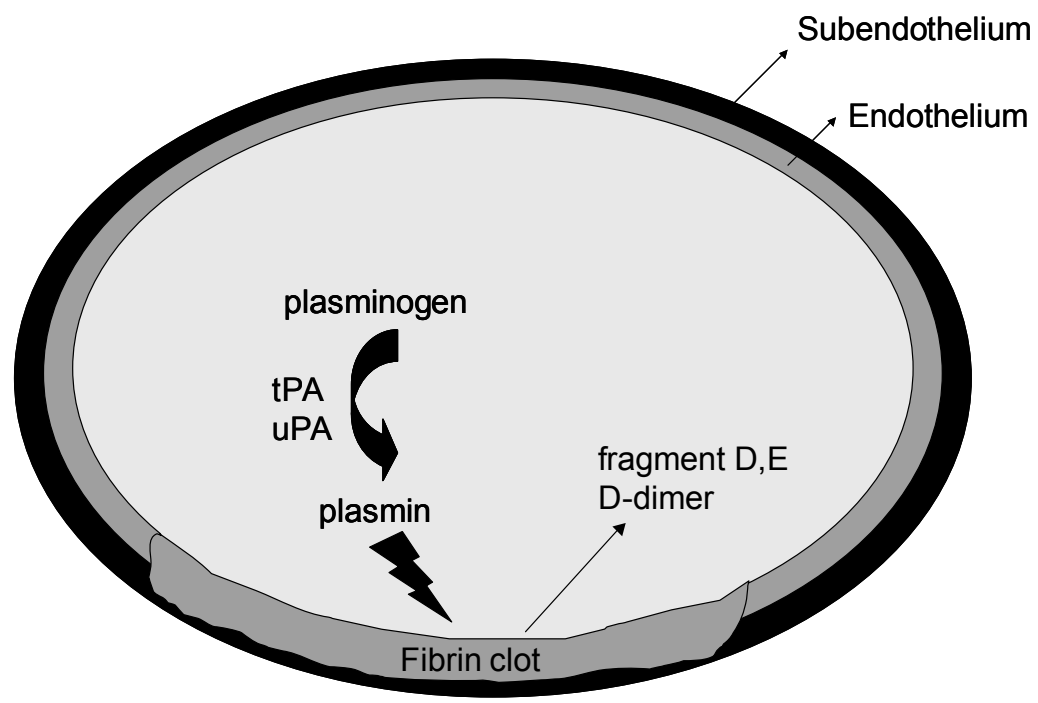

Figure 1.4a Cleaving of the fibrin network by plasmin and release of fibrin degradation products fragment $D$, fragment $E$ and $D$-dimer, tPA=tissue plasminogen activator, uPA=urokinase plasminogen activator.

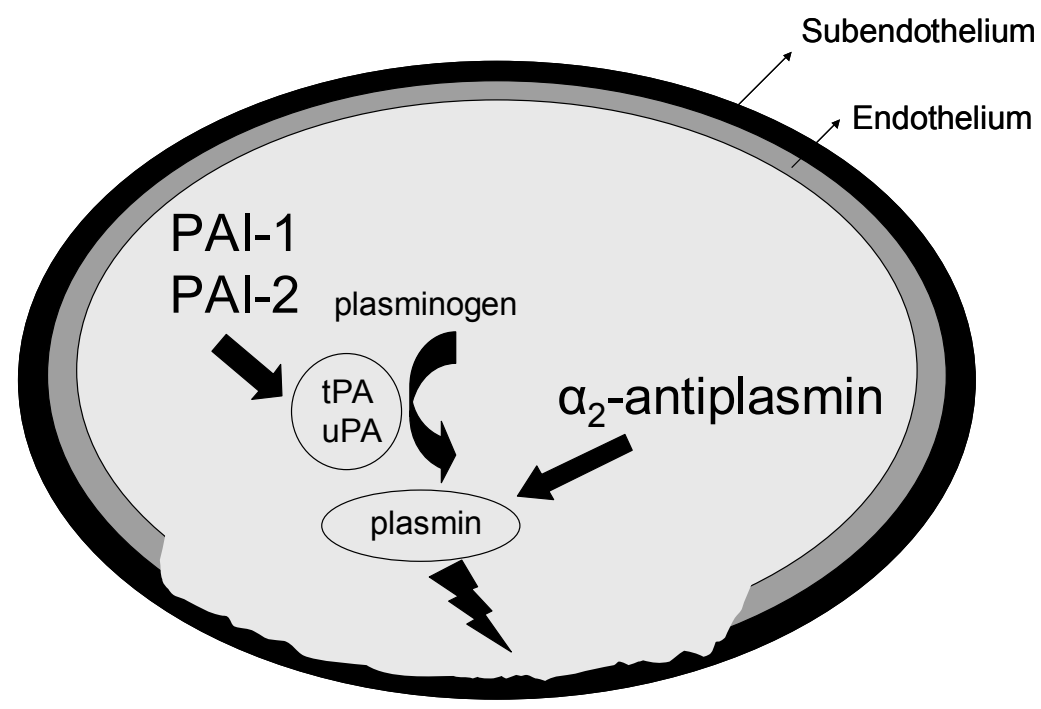

Figure 1.4b Inactivation of plasmin by alpha-2-antiplasmin and inhibition of IPA and UPA by plasminogen activator inhibitor (PAI) 1 and 2. 
It has been demonstrated that the fibrinolytic system, in particular the urokinase-type plasminogen activator system, is involved in the process of tumor cell invasion and metastasis. Urokinase-type plasminogen activator (UPA) binds to the urokinase-type plasminogen activator receptor (UPAR), among others present on tumor cells and monocytes, thus facilitating the conversion of plasminogen to plasmin. Plasmin is a protease not only able to cleave the fibrin network of a clot but, as mentioned before, also able to degrade the extracellular matrix, thereby allowing tumor cells and monocytes to invade the extracellular matrix and the surrounding tissues ${ }^{43}$ (Figure 1.4c).

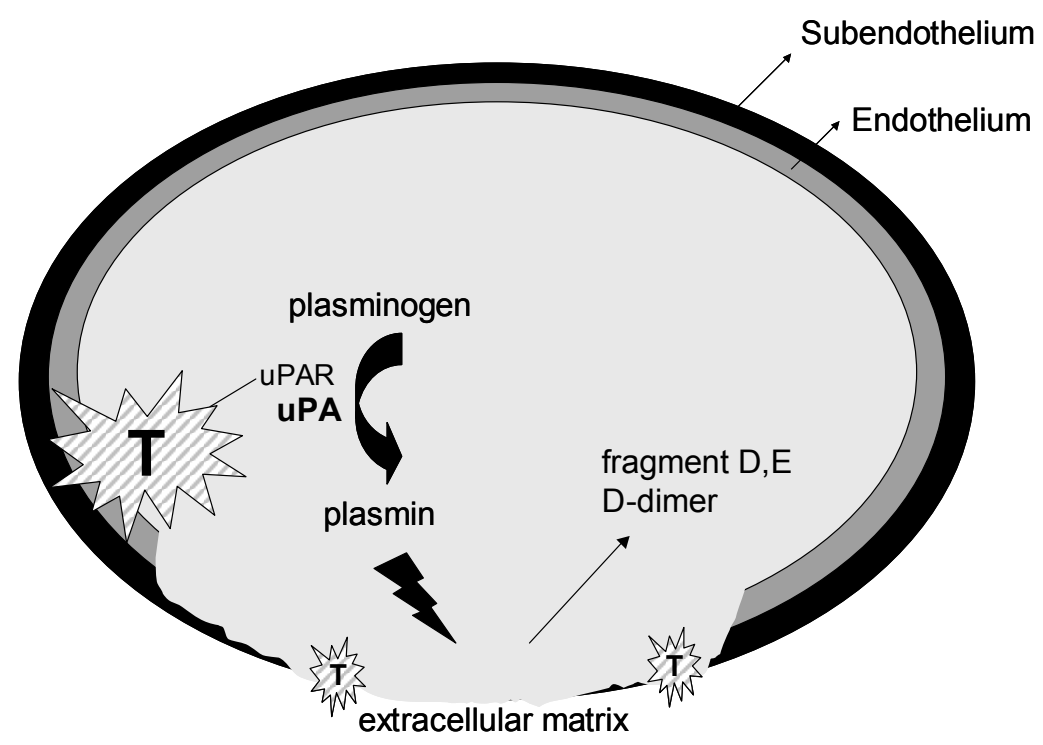

Figure 1.4c Urokinase-type plasminogen activator (UPA) binding to the urokinase-type plasminogen activator receptor (UPAR) on tumor cells, facilitating the conversion of plasminogen to plasmin, a protease cleaving the fibrin network and able to degrade the extracellular matrix, thereby allowing tumor cells $(T)$ to invade the extracellular matrix and the surrounding tissues.

Elevated tumor levels of UPA, UPAR and PAI-1 are associated with poor prognosis in various malignancies, including cancers of the lung, stomach, colorectum, bladder, ovary and breast ${ }^{46}$. Several studies have been done in patients with breast cancer. Breast cancer patients with high tumor levels of uPA had a significant shorter disease-free and overall survival, and the tumor uPA level is a strong prognostic marker in node-positive as well as nodenegative breast cancer patients ${ }^{47-53}$. High tumor levels of UPAR were associated with a shorter disease free and overall survival, particularly in the 
subgroup of node-positive postmenopausal women with breast cancer ${ }^{54,55}$. Tumor PAl-1 was a strong independent prognostic factor and an important parameter to predict metastatic potential in both node-negative and nodepositive breast cancer patients ${ }^{51,56,57}$. On the contrary, elevated tumor PAI-2 levels have been associated with favorable prognosis ${ }^{58,59}$. It has been demonstrated that the plasmalevels of soluble UPAR are significantly increased in patients with stage IV breast cancer ${ }^{60-62}$.

Elevated D-dimer levels, indicating the degradation of fibrin by the fibrinolytic system, have been described previously in breast cancer patients as well as in various other cancers ${ }^{63}$. Recently it has been demonstrated that in breast cancer patients preoperative plasma D-dimer levels correlate with clinical stage and axillary lymph node status ${ }^{64}$. Moreover, in patients with metastatic breast cancer, plasma D-dimer levels correlated with tumor volume, progression rate and survival ${ }^{65}$. In our studies plasma D-dimer levels were significantly elevated in the breast cancer patients with metastases compared to patients without metastases, and we found a highly significant correlation of plasma D-dimer levels with survival ${ }^{62}$.

In conclusion, the fibrinolytic system appears to play a significant role in the process of tumor cell invasion and metastasis.

\section{Angiogenesis: the link between cancer and the haemostatic system}

Angiogenesis is the development of new blood vessels from the existing vasculature. It occurs in a highly regulated manner in normal physiologic processes as wound healing. Angiogenesis is closely related to the haemostatic system in case of vascular damage. Following injury, the haemostatic system regulates the platelet adherence and fibrin formation, thereby stopping the bleeding; the angiogenic system regulates the formation of new blood vessels, a vital step in healing the wound. Once clot stabilization is achieved, angiogenesis is modulated by proteins and peptide fragments generated from the coagulation and fibrinolytic systems ${ }^{66,67}$. The fibrin clot, formed in the haemostatic process, serves as a matrix for migrating endothelial cells. This process is tightly regulated by a local balance of pro- and antiangiogenic factors. Pro-angiogenic factors stimulate migration, proliferation and differentiation of endothelial cells whereby new vessels are formed. Proangiogenic factors identified in the haemostatic system include platelet release products, as VEGF and platelet derived growth factor, and coagulation proteins as thrombin, TF, factor VII and factor XIII. Anti-angiogenic factors characterized from the haemostatic system are, among others, other platelet release products such as platelet factor 4 and thrombospondin, and coagulation 
proteins such as antithrombin and $\mathrm{PAI}-1^{68}$. In close cooperation the haemostatic system and the angiogenic system effectively repair the damaged blood vessel.

In 1971 Folkman first described the pivotal role of angiogenesis in tumor growth $^{69}$. For their growth tumors need oxygen and essential nutrients. When tumors are very small, oxygen and nutrients can diffuse into the tumor cells. In order to grow a tumor has to develop an adequate vasculature. By activating the haemostatic system tumor cells induce the production of pro-angiogenic factors as thrombin, TF and factor VII, thereby creating the environment for the formation of new blood vessels, comparable with physiologic angiogenesis. The fibrin locally formed by activation of the haemostatic system by the tumor cells provides the matrix on which the new (often thin walled, leaky and poorly organized) blood vessels are being formed by stimulation of the pro-angiogenic factors (Figure 1.5). The newly formed blood vessels allow the tumor to grow more rapidly and increase the surface area through which the tumor cells can escape and metastasize ${ }^{69}$.

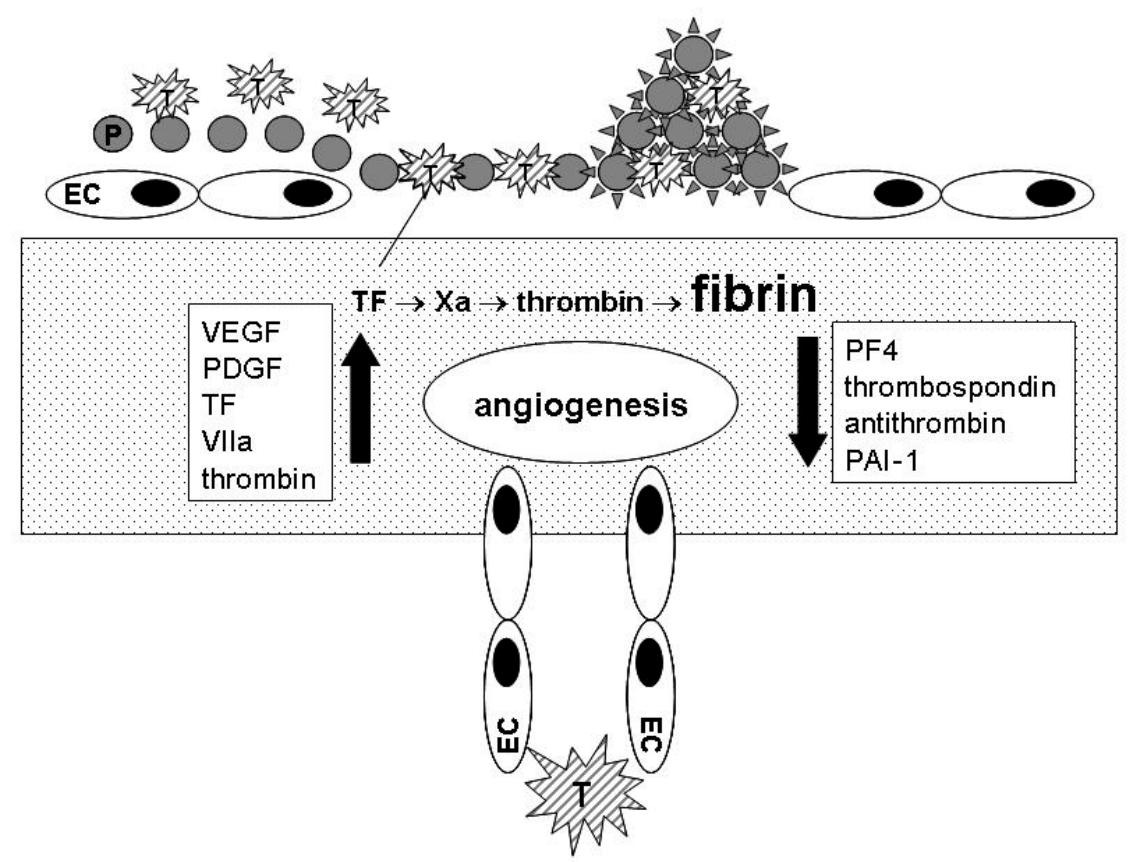

Figure 1.5 Activating of the haemostatic system by tumor cells and platelets leading to the production of pro-angiogenic factors (VEGF=vascular endothelial growth factor; PDGF=platelet derived growth factor; TF=tissue factor; VIla=activated coagulation factor VII) and anti-angiogenic factors (PF4=platelet factor 4), thereby creating the environment for the angiogenesis; the fibrin locally formed by activation of the haemostatic system by the tumor cells provides the matrix in which the new blood vessels are formed. 
In conclusion, tumor cells activate the haemostatic system as an essential step in the formation of new blood vessels, in order to grow and eventually metastasize.

\section{Anticoagulants and cancer}

Because cancer cells need the coagulation system for their growth, angiogenesis and dissemination, it has been hypothesized that anticoagulants might have an antitumor effect. Firstly, coumarin derivates were studied. Although promising results have been shown in animal studies, clinical studies in humans are limited and results are conflicting. No differences in survival were observed between warfarin-treated and control groups for advanced nonsmall cell lung, colorectal, head and neck and prostate cancer ${ }^{70}$. However, warfarin therapy was associated with a significant prolongation in disease free and overall survival in patients with small cell lung cancer ${ }^{70}$. Remarkably, in patients treated with coumarins for six months after a venous thromboembolism significantly fewer (urogenital) cancers were found compared with patients treated for six weeks ${ }^{71}$. However, the incidence of clinically overt cancer was not reduced in patients with idiopathic venous thromboembolism treated with oral anticoagulants for one year compared with three months ${ }^{72}$. More studies have been done with low molecular weight heparines (LMWH). In studies comparing LMWH and coumarins in the treatment of new patients with a venous thromboembolism three months mortality data suggested a survival advantage for the patients using LMWH. Subgroup analysis showed that this increased survival was in the cancer patient group ${ }^{73,74}$. Recently it has been shown that LMWH improves survival, although in all studies the effect seems limited to the patient groups with the relative better prognosis ${ }^{75-77}$. Moreover, adding LMWH to chemotherapy in small cell lung cancer improved survival compared to chemotherapy alone ${ }^{78}$. It is suggested that, apart from the effect of LMWH on coagulation, also other mechanisms influenced by heparins are involved $^{79,80}$. Additional studies treating cancer patients with LMWH or newer antithombotics, as pentasaccharides and oral thrombin inhibitors, are currently underway.

\section{Conclusion}

Almost a century and a half after Armand Trousseau first noted hypercoagulability in cancer patients, we are beginning to understand that many proteins of the haemostatic and fibrinolytic system play a pivotal role in the tumor biology. By activating the haemostatic and fibrinolytic systems tumor 
cells are able to grow, form new blood vessels and metastasize. This activation of the coagulation system leads to an increased risk of thromboembolism in cancer patients. More insight in the underlying mechanisms may lead to the development of new agents interfering with vital processes in tumor biology, that Armand Trousseau could not have even dreamed of. 


\section{References}

1. Hillen HFP. Thrombosis in cancer patients. Ann Oncol 2000;11 (suppl 3):273-6 .

2. Prins $\mathrm{MH}$, Otten HMMB. Thrombosis and cancer: a short history of Trousseau's syndrome. In: Thrombosis and Cancer, chapter 1. Taylor and Frances, $1^{\text {st }}$ print 2004.

3. Trousseau A. Phlegmasia alba dolens. In: Trousseau A, ed. Clinique médicale de l'Hôtel-Dieu de Paris.vol.3, 2nd ed. Ballière Paris 1865;3: 654-712.

4. Wojtukiewicz MZ, Sierko E, Rak J. Contribution of the hemostatic system to angiogenesis in cancer. Semin Thromb Hemost 2004;30:5-20.

5. Pinedo HM, Verheul HMW, D'Amato AJ, Folkman J. Involvement of platelets in tumour angiogenesis? Lancet 1998;352:1775-7.

6. Mohle R, Green D, Moore MAS, Nachman RL, Rafii S. Constitutive production and thrombin-induced release of VEGF by megakaryocytes and platelets. Proc Natl Acad Sci USA 1997;94:663-8.

7. Verheul HMW, Jorna A, Hoekman K, Broxterman HJ, Gebbink M, Pinedo HM. Vascular endothelial growth factor-stimulated endothelial cells promote adhesion and activation of platelets. Blood 2000;96:4216-21.

8. Gasic GJ, Gasic TB, Stewart CC. Antimetastatic effects associated with platelet reduction. Proc Natl Acad Sci USA 1968;61:46-52.

9. Nierodzik ML, Klepfish A, Karpatkin S. Role of platelet integrin GPIlb-GPIIla, fibronectin, von Willebrand factor, and thrombin in platelet-tumor interaction in vitro and metastasis in vivo. Thromb Haemost 1995;74:282-90.

10. Nieswandt B, Hafner M, Echtenacher B, Mannel DN. Lysis of tumor cells by natural killer cells in mice is impeded by platelets. Cancer Res 1999;59:1295-1300.

11. Falanga A, Marchetti M, Vignoli A. Pathogenesis of thrombosis in cancer. In: Thrombosis and cancer, Chapter 2. Taylor and Frances, $1^{\text {st }}$ print 2004.

12. Goldenberg N, Kahn SR, Solymoss S. Markers of coagulation and angiogenesis in cancer-associated venous thromboembolism. J Clin Oncol 2003;21:4194-9.

13. Röhsig LM, Damin DC, Stefani SD, Castro Jr. CG, Roisenberg I, Schwartsmann G. Von Willebrand factor antigen levels in plasma of patients with malignant breast disease. Braz J Med Biol Res 2001;34:1125-9.

14. Blann AD, Gurney D, Wadley M, Bareford D, Stonelake P, Lip GYH. Increased soluble P-selectin in patients with haematological and breast cancer: a comparison with fibrinogen, plasminogen activator inhibitor and von Willebrand factor. Blood Coagul Fibrinolysis 2001;12:43-50.

15. Damin DC, Rosito M, Gus P, Roisemberg I, Bandinelli E, Schwartsmann G. Von Willebrand factor in colorectal cancer. Int J Colorectal Dis 2002;17:42-5.

16. Floyd CM, Irani K, Kind PD, Kessler CM. Von Willebrand factor interact with malignant hematopoietic cell lines: evidence for the presence of specific binding sites and modification of von Willebrand factor structure and function. J Lab Clin Med 1992;119:467-76.

17. Oleksowicz L, Bhagwati N, DeLeon-Fernandez M. Deficient activity of von Willebrand's factor-cleaving protease in patients with disseminated malignancies. Cancer Res 1999;59:2244-50.

18. Butenas S, Bouchard BA, Brummel-Ziedins KE, Parhami-Seren B, Mann KG. Tissue factor activity in whole blood. Blood 2005;105:2764-70.

19. Falanga A, Gordon SG. Isolation and characterization of cancer procoagulant: a cysteine proteinase from malignant tissue. Biochemistry 1985;24:5558-67. 
20. Maiola A, Tua A, Grignani G. Hemostasis and cancer: tumor cells induce the expression of tissue factor-like procoagulant activity on endothelial cells. Haematologica 2002;87:624-8.

21. Giavazzi R, Foppolo M, Dossi R et al. Rolling and adhesion of human tumor cells on vascular endothelium under physiological flow conditions. J Clin Invest 1993;92:3038-44.

22. Edwards RL, Rickles FR, Cronlund M. Abnormalities of blood coagulation in patients with cancer. Mononuclear cell tissue factor generation. J Lab Clin Med 1981;98:917-28.

23. Morgan D, Edwards RL, Rickles FR. Monocyte procoagulant activity as a peripheral marker of clotting activation in cancer patients. Haemostasis 1988;18:55-65.

24. Semeraro N, Montemurro P, Conese M, Giordano D, Stella M, Restaino A, Cagnazzo G, Colucci M. Procoagulant activity of mononuclear phagocytes from different anatomical sites in patients with gynaecological malignancies. Int $\mathrm{J}$ Cancer 1990;45:251-4.

25. Semeraro N, Colucci M. Tissue factor in health and disease. Thromb Haemost 1997;78:759-64.

26. Ueno T, Toi M, Koike M, Nakamura S, Tominaga T. Tissue factor expression in breast cancer tissues: its correlation with prognosis and plasma concentration. $\mathrm{Br} \mathrm{J}$ Cancer 2000;83:164-70.

27. Sawada M, Miyake S, Ohdama S, Matsubara O, Masuda S, Yakumaru K, Yoshizawa $Y$. Expression of tissue factor in non-small-cell lung cancers and its relationship to metastasis. Br J Cancer 1999;79:472-7.

28. Shigemori C, Wada H, Matsumoto K, Shiku H, Nakamura S, Suzuki H. Tissue factor expression and metastatic potential of colorectal cancer. Thromb Haemost 1998;80:894-8.

29. Kakkar AK, Lemoine NR, Scully MF, Tebbutt S, Williamson SC.. Tissue factor expression correlates with histological grade in human pancreatic cancer. $\mathrm{Br} J$ Surg 1995;82:1101-4.

30. Carmeliet P, Mackman N, Moons L, Luther T, Gressens P, van Vlaenderen I, Demunck $H$, Kasper M, Breier G, Evrard $P$, Muller M, Risau W, Edgington T, Collen D. Role of tissue factor in embryonic blood vessel development. Nature 1996;383:73-5.

31. Carmeliet P, Ferreira V, Breier G, Pollefeyt S, Kieckens L, Gertsenstein M, Fahrig M, Vandenhoeck A, Harpal K, Eberhardt C, Declercq C, Pawling J, Moons L, Collen D, Risau W, Nagy A. Abnormal blood vessel development and lethality in embryos lacking a single VEGF allele. Nature 1996;380:435-9.

32. Zhang $Y$, Deng $Y$, Luther T, Muller M, Ziegler R, Waldherr R, Stern DM, Nawroth $\mathrm{PP}$. Tissue factor controls the balance of angiogenic and antiangiogenic properties of tumor cells in mice. J Clin Invest 1994;94:1320-7.

33. Bajaj MS, Birktoft JJ, Steer SA, Bajaj SP. Structure and biology of tissue factor pathway inhibitor. Thromb Haemost 2001;86:959-72.

34. Yang L, Manithody C, Rezaie AR. Heparin-activated antithrombin interacts with the autolysis loop of target coagulation proteases. Blood 2004;104:1753-9.

35. Dahlback B, Villoutreix BO. Regulation of blood coagulation by the protein C anticoagulant pathway: novel insights into structure-function relationships and molecular recognition. Arterioscler Thromb Vasc Biol 2005;25:1311-20. 
36. Nand S, Fisher SG, Salgia R, Fisher RI. Hemostatic abnormalities in untreated cancer: incidence and correlation with thrombotic and hemorrhagic complications. J Clin Oncol 1987;5:1998-2003.

37. Green D, Maliekel K, Sushko E, Akhtar R, Soff GA. Activated protein C resistance in cancer patients. Haemostasis 1997;27:112-8.

38. Haim N, Lanir N, Hoffman R, Haim A, Tsalik M, Brenner B. Acquired activated protein $C$ resistance is common in cancer patients and is associated with venous thromboembolism. Am J Med 2001;110:91-6.

39. Nijziel MR, van Oerle R, Christella M, Thomassen LG, van Pampus EC, Hamulyak $\mathrm{K}$, Tans G, Rosing J. Acquired resistance to activated protein $\mathrm{C}$ in breast cancer patients. Br J Haematol. 2003;120:117-22.

40. Iversen $\mathrm{N}$, Lindahl AK, Abildgaard U. Elevated TFPI in malignant disease: relation to cancer type and hypercoagulation. Br J Haematol 1998;102:889-95.

41. Iversen N, Lindahl AK, Abildgaard U. Elevated plasma levels of the factor Xa-TFPI complex in cancer patients. Thromb Res 2002;105:33-6.

42. Fischer EG, Riewald M, Huang HY, Miyagi Y, Kubota Y, Mueller BM, Ruf W. Tumor cell adhesion and migration supported by interaction of a receptor-protease complex with its inhibitor. J Clin Invest 1999;104:1213-21.

43. Schmitt M, Harbeck N, Thomssen C, Wilhelm O, Magdolen V, Reuning U, Ulm K, Höfler $\mathrm{H}$, Jänicke $\mathrm{F}$, Graeff $\mathrm{H}$. Clinical impact of the plasminogen activation system in tumor invasion and metastasis: prognostic relevance and target for therapy. Thromb Haemost 1997;78(1):285-96.

44. Chand HS, Du X, Ma D, Inzunza HD, Kamei S, Foster D, Brodie S, Kisiel W.The effect of human tissue factor pathway inhibitor-2 on the growth and metastasis of fibrosarcoma tumors in athymic mice. Blood 2004;103:1069-77

45. Dardik R, Loscalzo J, Inbal A. Factor XIII (fXIII) and angiogenesis. J Thromb Haemost 2006;4:19-25.

46. Andreasen PA, Kjøller L, Christensen L, Duffy MJ. The urokinase-type plasminogen activator system in cancer metastasis: a review. Int J cancer 1997; 72:1-22.

47. Duffy MJ, O'Grady P, Devaney D, O’Siorain L, Fennelly JJ, Lijnen HJ. Urokinaseplasminogen activator, a marker for aggressive breast carcinomas. Preliminary report. Cancer 1988;62(3): 531-3.

48. Jänicke F, Schmitt M, Ulm K, Gössner W, Graeff H. Urokinase-type plasminogen activator antigen and early relapse in breast cancer. Lancet 1989;2(8670):1049.

49. Duffy MJ, Reilly D, O'Sullivan C, O'Higgins N, Fennelly JJ, Andreasen P. Urokinase-plasminogen activator, a new and independent prognostic marker in breast cancer. Cancer Res 1990;50:6827-9.

50. Jänicke F, Schmitt M, Hafter R, Hollrieder A, Babic R, Ulm K, Gössner W, Graeff $\mathrm{H}$. Urokinase-type plasminogen activator (u-PA) antigen is a predictor of early relapse in breast cancer. Fibrinolysis 1990;4:69-78.

51. Grøndahl-Hansen J, Christensen IJ, Rosenquist C, Brünner N, Mouridsen HT, Danø K, Blichert-Toft M. High levels of urokinase-type plasminogen activator and its inhibitor PAI-1 in cytosolic extracts of breast carcinomas are associated with poor prognosis. Cancer Res 1993;53:2513-2521.

52. Foekens JA, Schmitt M, van Putten WLJ, Peters HA, Bontenbal M, Jänicke F, Klijn JGM. Prognostic value of urokinase-type plasminogen activator in 671 primary breast cancer patients. Cancer Res 1992;52:6101-5. 
53. Look MP, van Putten WL, Duffy MJ, Harbeck N, Christensen IJ, Thomssen C, Kates R, Spyratos F, Ferno M, Eppenberger-Castori S, Sweep CG, UIm K, Peyrat JP, Martin PM, Magdelenat H, Brunner N, Duggan C, Lisboa BW, Bendahl PO, Quillien V, Daver A, Ricolleau G, Meijer-van Gelder ME, Manders P, Fiets WE, Blankenstein MA, Broet P, Romain S, Daxenbichler G, Windbichler G, Cufer T, Borstnar S, Kueng W, Beex LV, Klijn JG, O'Higgins N, Eppenberger U, Jänicke F, Schmitt M, Foekens JA. Pooled analysis of prognostic impact of urokinase-type plasminogen activator and its inhibitor PAI-1 in 8377 breast cancer patients. J Natl Cancer Inst 2002;94:116-28.

54. Duggan C, Maguire T, McDermott E, O'Higgins N, Fennelly JJ, Duffy MJ. Urokinase plasminogen activator and urokinase plasminogen activator receptor in breast cancer. Int J Cancer 1995;61:597-600.

55. Grøndahl-Hansen J, Peters HA, van Putten WLJ, Look MP, Pappot H, Rønne E, Danø K, Klijn JGM, Brünner N, Foekens JA. Prognostic significance of the receptor for urokinase plasminogen activator in breast cancer. Clin Cancer Res 1995;1:1079-87.

56. Jänicke F, Schmitt M, Pache L, Ulm K, Harbeck N, Höffler H, Graeff H. Urokinase plasminogen activator (U-PA) and its inhibitor PAl-1 are strong and independent prognostic factors in node-negative breast cancer. Breast Cancer Res Treat 1993;24:195-208.

57. Foekens JA, Schmitt M, van Putten WLJ, Peters HA, Kramer MD, Jänicke F, Klijn JGM. Plasminogen activator inhibitor-1 and prognosis in primary breast cancer. J Clin Oncol 1994;12:1648-58.

58. Bouchet C, Spyratos F, Martin PM, Hacene K, Gentile A, Oglobine J. Prognostic value of urokinase-type plasminogen activator (u-PA) and plasminogen activator inhibitors PAI-1 and PAI-2 in breast carcinomas. Br J Cancer 1994;69:398-405.

59. Foekens JA, Buessecker F, Peters HA, Krainick U, van Putten WLJ, Look MP, Klijn JGM, Kramer MD. Plasminogen activator inhibitor-2: prognostic relevance in 1012 patients with primary breast cancer. Cancer Res 1995;55:1423-7.

60. Stephens RW, Pedersen AN, Nielsen HJ, Hamers MJAG, Høyer-Hansen G, Rønne E, Dybkjær E, Danø K, Brünner N. ELISA determination of soluble urokinase receptor in blood from healthy donors and cancer patients. Clin Chem 1997;43:1868-76.

61. Riisbro R, Christensen IJ, Piironen T, Greenall M, Larsen B, Stephens RW, Han C, Hoyer-Hansen G, Smith K, Brünner N, Harris AL. Prognostic significance of soluble urokinase plasminogen activator receptor in serum and cytosol of tumor tissue from patients with primary breast cancer. Clin Cancer Res 2002;8:1132-41.

62. Nijziel MR, van Oerle R, Hellenbrand D, van Pampus ECM, Hillen HFP, Hamulyák $\mathrm{K}$. The prognostic value of the soluble urokinase-type plasminogen activator receptor (s-uPAR) in plasma of breast cancer patients with and without metastatic disease. J Thromb Haemost 2003;1:982-6.

63. Mitter CG, Zielinski CC. Plasma levels of D-dimer: a crosslinked fibrin-degradation product in female breast cancer. J Cancer Res Clin Oncol 1991;117:259-62.

64. Blackwell K, Haroon Z, Broadwater G, Berry D, Harris L, Iglehart JD, Dewhirst M, Greenberg C. Plasma D-dimer levels in operable breast cancer patients correlate with clinical stage and axillary lymph node status. J Clin Oncol 2000;18: 600-8.

65. Dirix LY, Salgado R, Weytjens R, Colpaert C, Benoy I, Huget P, van Dam P, Prove A, Lemmens J, Vermeulen P. Plasma fibrin D-dimer levels correlate with tumour volume, progression rate and survival in patients with metastatic breast cancer. $\mathrm{Br}$ J Cancer 2002;86:389-95. 
66. Staton CA, Lewis CE. Angiogenesis inhibitors found within the haemostasis pathway. J Cell Mol Med 2005;9:286-302.

67. Browder T, Folkman J, Pirie-Shephered S. The hemostatic system as a regulator of angiogenesis. J Biol Chem 2000;275:1521-4.

68. Dardik R, Loscalzo J, Inbal A. Factor XIII (FXIII) and angiogenesis. J Thromb Haemost 2006;4:19-25.

69. Folkman J. Tumor angiogenesis: therapeutic implications. $\mathrm{N}$ Engl J Med 1971;285:1182-6.

70. Zacharski LR, Henderson WG, Rickles FR, Forman WB, Cornell CJ Jr, Forcier RJ, Edwards RL, Headley E, Kim SH, O'Donnell JF. Effect of warfarin anticoagulation on survival in carcinoma of the lung, colon, head and neck, and prostate. Final report of VA Cooperative Study \#75. Cancer 1984;53:2046-52.

71. Schulman S, Lindemarker $P$. Incidence of cancer after prophylaxis with warfarin against recurrent venous thromboembolism. Duration of Anticoagulation Trial. $\mathrm{N}$ Engl J Med 2000;342:1953-8.

72. Taliani MR, Agnelli G, Prandoni P, Becattini C, Moia M, Bazzan M, Ageno W, Tomasi C, Guazzaloca G, Ambrosio GB, Bertoldi A, Salvi R, Poggio R, Silingardi M; Warfarin Optimal Duration Italian Trial (WODIT) Investigaters. Incidence of cancer after a first episode of idiopathic venous thromboembolism treated with 3 months or 1 year of oral anticoagulation. J Thromb Haemost 2004;2:377-8.

73. Prandoni $P$, Lensing AW, Buller HR, Carta M, Cogo A, Vigo M, Casara D, Ruol A, ten Cate JW. Comparison of subcutaneous low-molecular-weight heparin with intravenous standard heparin in proximal deep-vein thrombosis. Lancet 1992;339:441-5.

74. Hettiarachchi RJ, Smorenburg SM, Ginsberg J, Levine M, Prins MH, Buller HR. Do heparins do more than just treat thrombosis? The influence of heparins on cancer spread. Thromb Haemost 1999;82:947-52.

75. Klerk CP, Smorenburg SM, Otten HM, Lensing AW, Prins MH, Piovella F, Prandoni $P$, Bos MM, Richel DJ, van Tienhoven G, Buller HR. The effect of low molecular weight heparin on survival in patients with advanced malignancy. J Clin Oncol 2005;23:2130-5.

76. Lee AY, Rickles FR, Julian JA, Gent M, Baker RI, Bowden C, Kakkar AK, Prins M, Levine MN. Randomized comparison of low molecular weight heparin and coumarin derivatives on the survival of patients with cancer and venous thromboembolism. J Clin Oncol 2005;23:2123-9.

77. Kakkar AK, Levine MN, Kadziola Z, Lemoine NR, Low V, Patel HK, Rustin G, Thomas M, Quigley M, Williamson RCN. Low molecular weight heparin, therapy with dalteparin, and survival in advanced cancer: the Fragmin Advanced Malignancy Outcome Study (FAMOUS). J Clin Oncol 2004;22:1944-8.

78. Altinbas M, Coskun HS, Er O, Ozkan M, Eser B, Unal A, Cetin M, Soyuer S. A randomized clinical trial of combination chemotherapy with and without lowmolecular-weight-heparin in small cell lung cancer. J Thromb Haemost 2004;2:1266-71.

79. Stevenson JL, Choi SH, Wahrenbrock M, Varki A, Varki NM. Heparin effects in metastasis and Trousseau's syndrome: anticoagulation is not the primary mechanism. Haemotologica Reports 2005;1(9):59-60.

80. Mousa SA. Inhibition of tumor growth by heparins in vivo. Haematologica Reports 2005;1(9):63. 


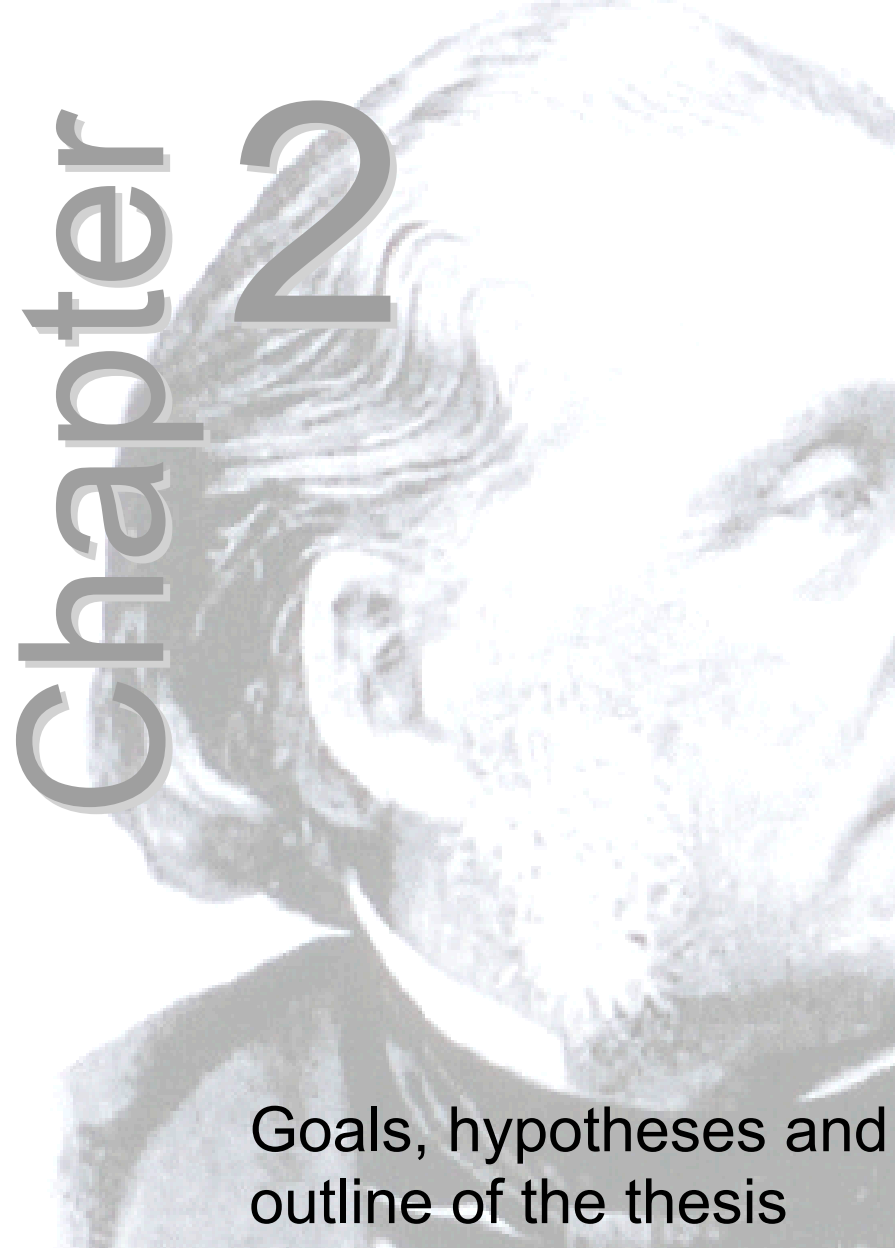

Marten R Nijziel 
The "modification of the blood" in patients with thrombosis and cancer, as hypothesized by Armand Trousseau in 1865, is currently the subject of extensive clinical and preclinical research. This thesis focuses on new delicate markers and mechanisms of hypercoagulability in cancer patients. Several new tests were evaluated in cancer patients for the first time. Even minor changes in the markers could indicate activation of the haemostatic system and could be a sign of the presence of tumor cells. The presence of tumor cells has major therapeutic and prognostic implications in the treatment of cancer patients. Therefore, evaluation of these new markers could lead to further understanding the mechanisms of hypercoagulability in cancer patients and provide the basis for the development of new therapeutics that influence tumor cell growth.

We therefore investigated a variety of cancer related hypercoagulability factors: procoagulant factors, anticoagulant factors, factors related to the fibrinolytic system and factors related to the endothelium.

\section{Procoagulant factors: monocyte tissue factor expression, antigen and activity}

One of the possible pathways whereby a cancer cell can activate the coagulation system is by the induction of tissue factor (TF) on monocytes. We therefore planned to evaluate the hypothesis that elevated numbers of TFbearing monocytes might be one of the causes of cancer associated thrombosis. Although there is evidence in vitro, there is only limited evidence in vivo of monocyte TF activation in cancer patients. Most of the published studies are in vitro studies before 1990. In 1995 the research group of Østerud introduced the so called "high and low responder phenomenon" as explanation of the remarkable difference in TF expression on monocytes between healthy individuals. Monocytes of high responders express more TF upon stimulation than monocytes of low responders. It has been suggested that these high responders are more prone to coronary artery disease and thromboembolism. We hypothesized that cancer patients could shift to high responders and could express more TF on monocytes contributing to the cancer-related hypercoagulability.

In Chapter 3 we describe the influence of plasma factors on the high and low responder phenomenon of monocyte TF activity in healthy individuals with a newly developed test measuring the monocyte TF activity by plasma stimulation of isolated monocytes. In Chapter 4 we describe monocyte TF activity in healthy controls and a heterogenic group of cancer patients after a 
direct work-up of unstimulated whole blood measured by flowcytometry. In Chapter 5 we show a direct comparison of the two tests described in Chapters 3 and 4: monocyte TF activity measured by flowcytometry compared with monocyte TF activity measured by plasma stimulation of isolated monocytes. We hypothesized that a possible mechanism of monocyte TF activity in cancer patients is that these patients shift from low to high responders, thereby expressing more TF than healthy controls upon stimulation by plasma. We measured patients with breast and colorectal cancer in comparison with healthy individuals.

\section{Anticoagulant factors: acquired resistance to activated protein C (APC)}

Cancer related hypercoagulability has mainly been attributed to activation of procoagulant pathways with increased levels of several coagulation factors. The possibility of decreased levels of anticoagulant factors has gained less attention. In the laboratory of the Department of Biochemistry of the Maastricht University a very sensitive new test has been developed to evaluate the effect of APC on the thrombin generation initiated via the extrinsic coagulation pathway. Because the extrinsic coagulation pathway is activated in cancer patients, we hypothesized that they could have an acquired resistance to activated protein $\mathrm{C}$ contributing to Trousseau's syndrome. Results of this study have been described in Chapter 6 .

\section{Factors related to the fibrinolytic system: urokinase-type plasminogen activator receptor}

It has been demonstrated that the fibrinolytic system, in particular the urokinase-type plasminogen activator system, is involved in the process of tumor cell invasion and metastasis. Urokinase-type plasminogen activator (UPA) binds to the urokinase-type plasminogen activator receptor (UPAR), among others present on tumor cells and monocytes, thus facilitating the conversion of plasminogen to plasmin. Plasmin is a protease able to degrade the extracellular matrix directly or indirectly by activating matrix metalloproteinases. These matrix metalloproteinases degrade collagen and other matrix proteins, thereby allowing tumor cells and monocytes to invade the extracellular matrix and the surrounding tissues. The soluble urokinase-type plasminogen activator receptor (s-uPAR) is a newly available plasma marker for local expression and release of UPAR. In Chapter 7 we studied s-uPAR levels in patients with a breast carcinoma in plasma samples collected during 
follow-up after the primary treatment with surgery, radiotherapy and chemotherapy. At the same time we studied other fibrinolytic parameters functionally related to the urokinase-type plasminogen activator system. We hypothesized that in patients without known metastases elevated levels could be predictive parameters for future metastatic disease and that in patients with known metastases elevated levels could be inversely correlated with survival. Moreover, we measured the urokinase-type plasminogen activator receptor (UPAR) on monocytes of cancer patients and controls after a direct work-up of unstimulated whole blood by flowcytometry in Chapter 4 .

\section{Factors related to the endothelium: von Willebrand Factor and APC resistance}

In cancer patients endothelial cell activation is one of the mechanisms inducing cancer-related hypercoagulability. Increased von Willebrand Factor levels, as a marker of endothelial activation, have been reported previously. In addition, APC resistance can be regarded as endothelial cell mediated, as the activation of protein $C$ requires the binding of thrombin to the endothelial cell membrane glycoprotein thrombomodulin and the binding of protein $\mathrm{C}$ to the endothelial cell protein $\mathrm{C}$ receptor. Therefore in Chapter 8 we studied von Willebrand Factor levels and APC resistance in relation to prognosis. We prospectively followed breast cancer patients for more than five years to see whether elevated levels of von Willebrand Factor and/or acquired resistance to activated protein $\mathrm{C}$ were the first signs of future metastatic disease in patients without metastases and to see whether elevated levels of von Willebrand Factor or resistance to activated protein $\mathrm{C}$ implicated more advanced disease and a worse prognosis in patients with metastases.

With these studies we aimed at gaining further insight into the intriguing syndrome of hypercoagulability in cancer patients, first recognized by the legendary Armand Trousseau. 


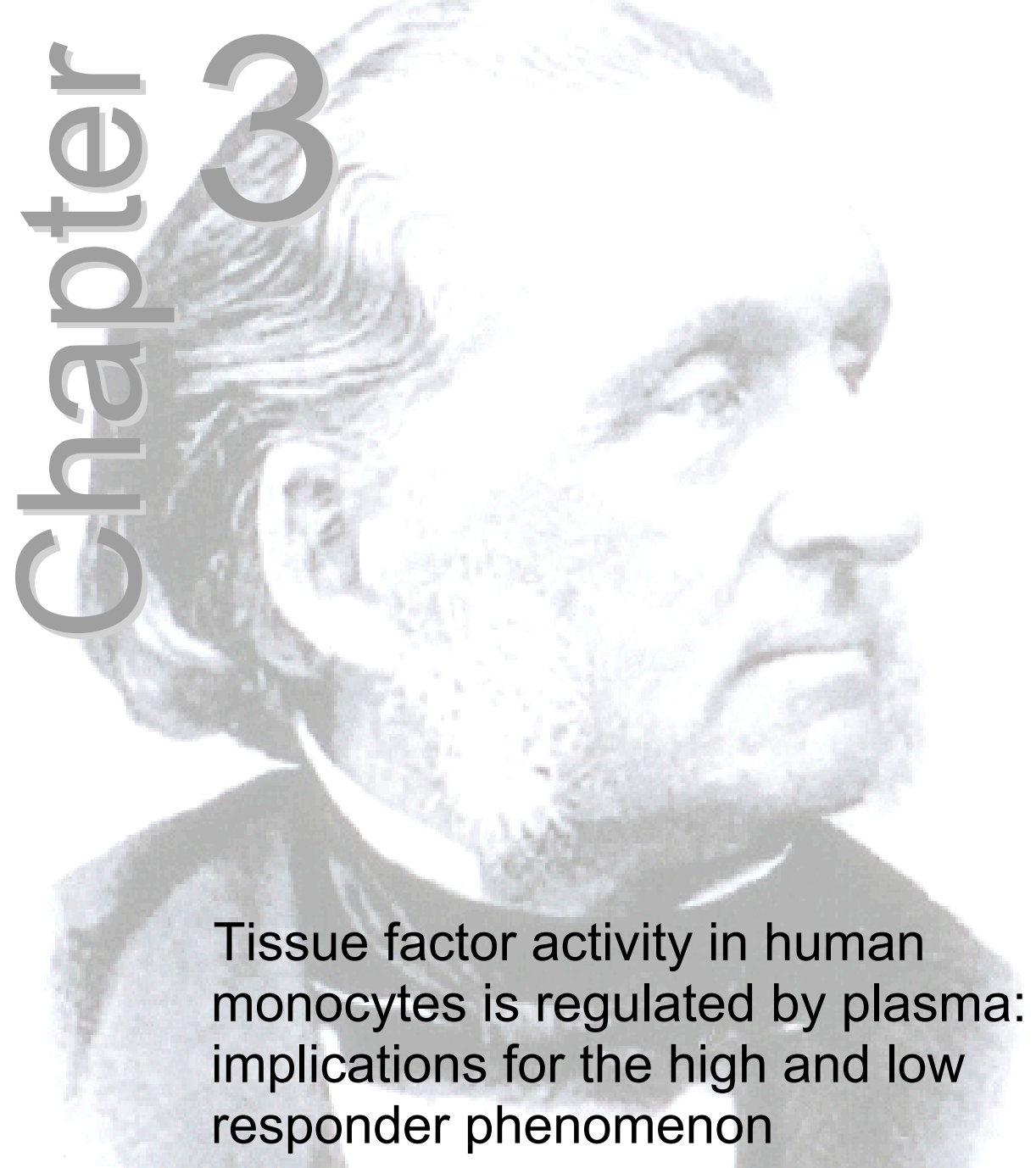

Marten R Nijziel, René van Oerle, Cornelis van 't Veer, Elisabeth CM van Pampus, Theo Lindhout, Karly Hamulyák Br J Haematol 2001;112:98-104 


\section{Summary}

The "high and low responder phenomenon" of monocyte tissue factor (MTF) activity has been attributed to effects on monocytes by granulocytes, platelets and LPS. To study a possible contribution of plasma to the high and low responder phenomenon, we measured the MTF activity in isolated cryopreserved human monocytes from two donors (monocytes $A$ and monocytes B) after incubation in a plasma environment depleted of granulocytes, platelets and LPS.

In buffer only MTF activity was 643 and $679 \mathrm{fM}$, in normal pooled plasma 1478 and $1615 \mathrm{fM}(p=0.001)$ respectively in monocytes $A$ and in monocytes $B$. Incubation with individual plasma samples of healthy controls $(n=43)$ gave median MTF of $1355 \mathrm{fM}$ (range 1044 to $1976 \mathrm{fM}$ ) and $1329 \mathrm{fM}$ (range 858 to $1951 \mathrm{fM}$ ). A plasma consistently induced a higher or lower level of MTF activity in both monocytes: $r=0.82(p<0.00001)$. Coumarin use did not influence the high and low responder phenomenon.

In the absence of granulocytes, platelets and LPS plasma determines the high and low responder phenomenon. This phenomenon is not influenced by coumarin treatment. 


\section{Introduction}

Monocyte tissue factor (MTF) activity is appreciated to play a pivotal role in a variety of physiological and pathophysiological processes as disseminated intravascular coagulation, atherosclerosis, arterial and venous thromboembolism, cancer related hypercoagulability and angiogenesis ${ }^{1,2}$. Extensive research has been done to elucidate the mechanism of MTF activity and the factors involved. MTF activity is stimulated by adherence of monocytes to a surface leading to cell signal transduction by activation of phospholipases ${ }^{3,4}$. Lipopolysaccharide (LPS), immune complexes and activated complement factor $5(\mathrm{C} 5 \mathrm{a})$ are involved in the primary induction of MTF in vivo ${ }^{5}$. Other factors are only of importance in enhancing MTF in already stimulated monocytes ${ }^{5}$.

Upon stimulation monocytes of some individuals express more TF than monocytes of others. This so-called "high and low responder phenomenon" was defined as a 50-fold difference in MTF activity between the highest responder and the lowest responder in LPS stimulated whole blood ${ }^{6}$. Platelets are partly responsible for this phenomenon ${ }^{7}$. Platelet rich plasma induced significantly more TF in LPS stimulated monocytes than platelet poor plasma ${ }^{8,9}$. Platelets of low responders have been reported to inhibit TF in monocytes from high responders ${ }^{10}$. Granulocytes enhanced LPS induced MTF by an interaction with platelets involving P-selectin, Platelet Factor 4 (PF4) and Platelet Activating Factor $(\mathrm{PAF})^{8,11,12}$. It has been suggested that this high MTF response in individuals upon stimulation is associated with coronary artery disease and thrombosis ${ }^{6}$.

Serum and plasma enhanced MTF generation in cultures of normal peripheral mononuclear cells ${ }^{13}$. Because the high responder phenomenon is only partially understood, we hypothesized that the differences in MTF activity between high and low responders might be determined by differences in the plasma independent of granulocytes, platelets and LPS. Therefore, MTF activity was measured in isolated human monocytes after incubation in a plasma environment depleted of granulocytes, platelets and LPS. Plasma of healthy volunteers and of individuals using oral anticoagulant therapy was evaluated.

\section{Materials and methods}

\section{Reagents}

Sterile LPS free Hanks balanced salt solution (HBSS) without calcium and magnesium (Cat. no. 14175-053) was purchased from Gibco BRL, Life Technologies Ltd., Scotland. Calcium and magnesium (P.A. grade) were obtained from Sigma, the Netherlands. Unfractionated heparin was purchased 
from Leo Pharmaceutical Products, the Netherlands and polymyxin B from Genfarma B.V., the Netherlands. LPS (E.coli 0128:B12) was obtained from Difco Laboratories. Cycloheximide was purchased from ICN Biomedicals B.V., the Netherlands, actinomycin D from Boehringer Mannheim $\mathrm{GmbH}$, Germany and polyclonal rabbit anti-human tissue factor $\lg G$ from American Diagnostica, U.S.A. Tris/EDTA buffer (Tris HCl 50mM, NaCl $175 \mathrm{mM}$, disodium EDTA 20 $\mathrm{mM}$; pH 7.4) was obtained from ICN Biomedicals B.V., the Netherlands. Prothrombin was a kind gift from Dr. T. Hackeng, bovine factor $V$ from Dr. R. Wagenvoord and the phospholipid vesicles DOPS/DOPC 20/80 from Professor Dr. J. Rosing. Human recombinant factor VIla was purchased from Novo Nordisk, Denmark. Relipidated tissue factor in PS/PC vesicles 20/80 was a gift from Dr. T. Lindhout. Bovine factor $X$ and the HEPES/BSA buffer were obtained from Sigma, the Netherlands. The chromogenic substrate S2238 was purchased from Chromogenix, Sweden.

All reagents, plasma and cells were tested for endotoxin contamination by the Limulus assay (Limulus Amebocyte Lysate, COATEST ${ }^{\circledR}$ Endotoxin, Chromogenix $A B$, Sweden) and were negative at levels $<0.05 \mathrm{EU} / \mathrm{ml}$.

\section{Blood collection and plasma preparation}

Blood $(40 \mathrm{ml}$ ) was collected from the antecubital vein without venous stasis using a Strauß Kanüle 1,2x43 mm (Lameris, the Netherlands). The first $4 \mathrm{ml}$ were discarded. The rest was collected into four $10 \mathrm{ml}$ plastic tubes $(16,8 \times 100 \mathrm{~mm}, 164180$, Greiner, Germany) containing $1 \mathrm{ml}$ of sodium citrate $3.8 \%$ each. For the experiments with plasma of individuals using oral anticoagulant therapy blood $(6.3 \mathrm{ml})$ was collected with a Vacutainer PrecisionGlide ${ }^{\mathrm{TM}}$ needle $0.8 \times 38 \mathrm{~mm}$ into two Vacutainer $^{\circledR}$ tubes containing $0.129 \mathrm{M}$ sodium citrate (both Becton Dickinson Europe, France). Citrated platelet poor plasma was made using two centrifuge steps: five minutes 4000 $\mathrm{rpm}$ and ten minutes $11000 \mathrm{rpm}$. The blood samples were processed within 30 minutes after the collection. The plasma samples were stored at $-70^{\circ} \mathrm{C}$ in aliquots of $500 \mu$ until analysis.

\section{Subjects}

Normal pooled plasma was used of 64 healthy volunteers not using any medication. Secondly, experiments were done with individual plasma samples of 43 other healthy controls not using any medication: 18 men, 25 women; mean age $59.7 \pm 9.0$ years, range 45 to 79 years. Next experiments were done with plasma of 22 consecutive individuals on stable long-term coumarin anticoagulants for prophylactic use (thirteen men, nine women; mean age $61.7 \pm 6.9$ years, range 49 to 69 years) and 22 healthy controls (ten men, twelve women, mean age $62.5 \pm 8.3$ years, range 49 to 79 ). The INR (mean \pm sd) was $2.8 \pm 0.6$ in the treatment group and $1.0 \pm 0.1$ in the control group. Finally, 
experiments were performed with plasma of fourteen individuals (three men, eleven women; mean age $70.7 \pm 13.8$ years, range 45 to 90 years) using coumarin anticoagulants for three months after hip arthroplasty because of osteoarthrosis (eleven individuals) or hip fracture (three individuals). Blood was collected when the patient was on stable anticoagulation during use of coumarins and four weeks after cessation of the anticoagulant treatment. The INR (mean \pm sd) in this group was $2.0 \pm 0.5$.

\section{Monocyte purification and preservation}

Peripheral blood monocytes were obtained from two healthy non-smoking donors, male 43 years (monocytes A) and female 48 years old (monocytes B), both not using any medication. This was done by leukapheresis, followed by sterile multiple chamber counterflow centrifugation (MCCC) at $4^{\circ} \mathrm{C}$. The citrated $(0.13 \mathrm{M})$ leukocyte concentrate, obtained by leukapheresis, was diluted in PBS buffer with $0.2 \%$ human serum albumin (CLB, Amsterdam, the Netherlands) and $0.2 \%$ glucose $(\mathrm{pH} 7.3)$. After density gradient centrifugation on Percoll $1.073 \mathrm{~g} / \mathrm{ml}$ at $4^{\circ} \mathrm{C}$, the mononuclear fraction was purified in a four-chamber sterile CCE rotor (Curameé 3000 system; Dijkstra Vereenigde B.V, Amsterdam, the Netherlands) constantly controlling the outflow by using a computerized scatter-monitor device, as described previously ${ }^{14}$. In short, under a constant flow rate and a constant rotor speed, cells were loaded up to $2 \times 10^{9}$ cells per chamber. PBS buffer with $0.2 \%$ human serum albumin and $0.2 \%$ glucose was used as elutriant. By reducing the rotor speed stepwise cell fractions were washed out and fractions containing more than $93 \%$ monocytes were collected. The cells were pooled and resuspended in a final concentration of $5 \times 10^{6} \mathrm{cells} / \mathrm{ml}$ in a freeze medium consisting of $30 \%$ autologous citrated plasma, 60\% Iscove's (Gibco) and 10\% DMSO (Dimethylsulfoxid, Merck). Next the cells were frozen at $-180^{\circ} \mathrm{C}$ in aliquots of $1 \mathrm{ml}$ in sterile cryovials (Greiner, Germany) in a cryostat (Planner Kryo 10; Cryotech Benelux, Schagen, the Netherlands) using a standard controlled freezing procedure.

\section{Monocyte culturing}

After thawing at room temperature the cryopreserved monocytes had a viability of $85 \%$ as shown by trypan blue exclusion. The cells were washed twice at $4^{\circ} \mathrm{C}$ with sterile LPS free Hanks balanced salt solution (HBSS) without calcium and magnesium. In a 96 wells round bottom microtitre plate (Cat. No. 163320, Nunclon ${ }^{\mathrm{TM}}$, Nalge Nunc International, Denmark) $1.0 \times 10^{5}$ monocytes per well were cultured for three hours at $37^{\circ} \mathrm{C}$ with addition of $10 \mu \mathrm{l}$ calcium and magnesium (final concentration per well: $5 \mathrm{mM}$ and $2 \mathrm{mM}$ respectively) and $10 \mu \mathrm{l}$ unfractionated heparin $(2.5 \mathrm{U} / \mathrm{ml})$. In all buffer and plasma experiments $10 \mu \mathrm{l}$ polymyxin $\mathrm{B}(10 \mu \mathrm{g} / \mathrm{ml})$ was added to prevent a stimulatory effect on the 
MTF activity by trace amounts of LPS in any of the reagents or monocyte cultures.

In the plasma experiments $40 \mu \mathrm{l}$ citrated platelet poor plasma was added, which was $20 \%$ of the total volume of $200 \mu$ per well. In a whole blood system citrate induced a lower MTF activity compared to heparin, due to its depleting effect on plasma calcium which is essential in the signal transduction leading to MTF activity ${ }^{15}$. We could not demonstrate any difference in MTF activity between the recalcified heparinized citrated plasma used in the experiments and heparinized plasma of the same subject. In control experiments citrate or heparin alone did not evoke MTF activity (data not shown).

In the LPS experiments $10 \mu \mathrm{l}$ LPS $(25 \mathrm{ng} / \mathrm{ml})$ was added. These were the only experiments in which no polymyxin B was added, unless otherwise stated. Where mentioned $10 \mu \mathrm{l}$ cycloheximide $(12.5 \mu \mathrm{g} / \mathrm{ml}), 10 \mu \mathrm{l}$ actinomycin $\mathrm{D}$ $(5 \mu \mathrm{g} / \mathrm{ml})$ or $7.5 \mu \mathrm{l}$ polyclonal rabbit anti-human tissue factor $\operatorname{lgG}(1 \mathrm{mg} / \mathrm{ml})$ were added. In all experiments the total volume per well was completed to $200 \mu$ with HBSS.

After the three hour incubation period the monocytes were washed with Tris/EDTA buffer and then twice with HBSS. Between the washing steps the cells were centrifuged in the microtitre plate for three minutes at $150 \mathrm{~g}$. Finally $50 \mu \mathrm{HBSS}$ per well was added. After three freeze-thaw steps to lyse the cells the microtitre plate was stored at $-70^{\circ} \mathrm{C}$ until tissue factor measurement.

\section{Tissue factor assay}

Monocyte tissue factor activity was measured using a two-stage tissue factor assay measuring thrombin at $37^{\circ} \mathrm{C}$. After thawing the lysed cells, $1.25 \mu \mathrm{M}$ prothrombin, $160 \mathrm{pM}$ bovine factor $\mathrm{V}$ and $20 \mu \mathrm{M}$ phospholipid vesicles DOPS/DOPC 20/80 in $25 \mu$ l HEPES/BSA buffer with $5 \mathrm{mM}$ calcium was added. Next $25 \mu$ of a HEPES/BSA buffer containing $0.5 \mathrm{nM}$ human recombinant factor VIla, $10 \mathrm{nM}$ bovine factor $X$ and $5 \mathrm{mM}$ calcium was added. After exactly three minutes of incubation under constantly shaking, $25 \mu \mathrm{l}$ of the mix was transferred into $175 \mu \mathrm{l}$ Tris/EDTA buffer to stop thrombin formation. Thrombin was measured by adding $50 \mu \mathrm{l}$ chromogenic substrate $\mathrm{S2238}$ (final concentration $0.2 \mathrm{mM}$ ). Substrate conversion was measured kinetically on a Biorad microtitre plate reader at $37^{\circ} \mathrm{C}$. Under the conditions of the assay the rate of substrate conversion is proportional to the tissue factor concentration in the lysed cells. Concentrations are expressed in fM tissue factor (final concentration) by comparison to a standard curve of known tissue factor concentrations. Calculated concentrations were means of at least triple simultaneous measurements in the same microtitre plate. 


\section{Statistics}

To compare the MTF activity in buffer, normal plasma and LPS an independent-samples T-test was used. To compare the MTF activity in the oral anticoagulant group and the healthy controls a Mann-Whitney U-test was performed. To compare the MTF activity during and after coumarin anticoagulant therapy the Wilcoxon signed ranks test for two dependent samples was used. Spearman correlation coefficients were calculated. Values are given as medians and range. Differences were considered significant at $p<0.05$.

\section{Results}

After three hours of incubation in HBSS buffer (buf) MTF activity was 643 and $679 \mathrm{fM}$ respectively in monocytes $\mathrm{A}$ and in monocytes $\mathrm{B}$. In normal pooled plasma (npl) MTF was significantly increased to 1478 and $1615 \mathrm{fM}(p=0.001)$. Incubation with LPS $(25 \mathrm{ng} / \mathrm{ml})$, without polymyxin B, gave a MTF of 2812 and $3055 \mathrm{fM}$ respectively ( $p<0.0005$ compared to buffer, $p=0.001$ compared to normal pooled plasma). Adding polymyxin B $(10 \mu \mathrm{g} / \mathrm{ml})$ to LPS reduced MTF to the buffer level (Figure 3.1).

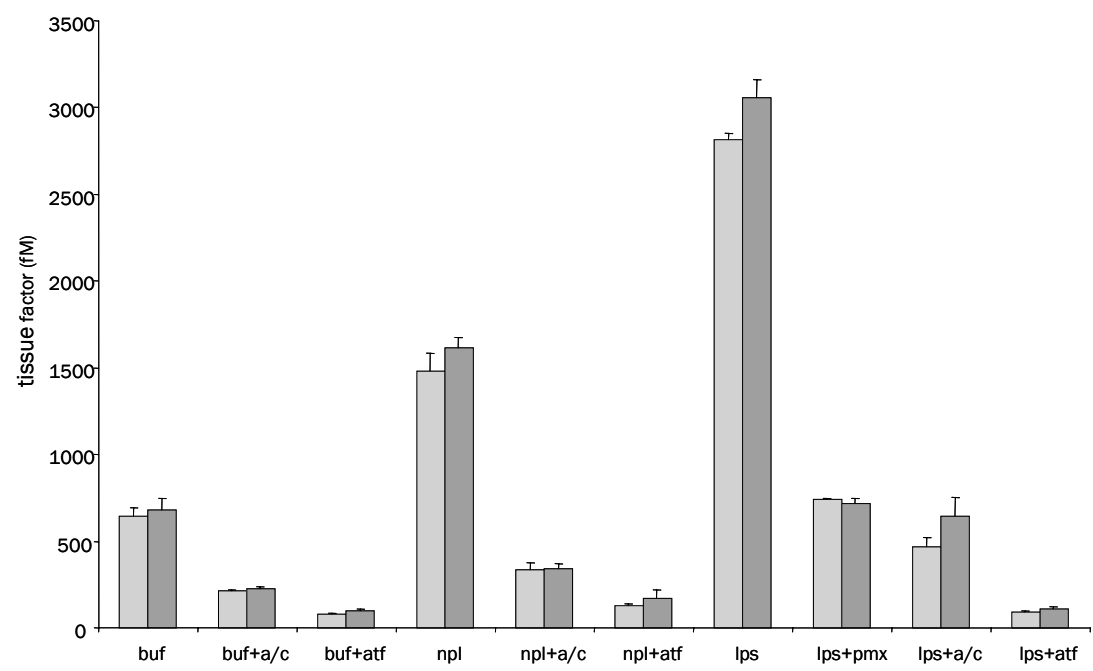

Figure 3.1 Monocyte tissue factor (MTF) activity in fM tissue factor measured in monocytes from two donors, monocytes A (grey bars) and monocytes B (dark grey bars), incubated for three hours with HBSS (buf), actinomycin $D$ and cycloheximide $(\mathrm{a} / \mathrm{c})$, rabbit anti human tissue factor (atf), normal pooled plasma (npl), lipopolysaccharide (Ips) and/or polymyxin $B(\mathrm{pmx})$. In the buffer and normal pooled plasma experiments polymyxin B $(10 \mu \mathrm{g} / \mathrm{ml})$ was always added. In the LPS experiments polymyxin B was not added, unless indicated in the figure. Data are presented as means $\pm s d \quad(n=8$, triple measurements). 
One hour of pre-incubation before the normal incubation period with the transcription inhibitor actinomycin $\mathrm{D}$, the protein synthesis inhibitor cycloheximide or both $(\mathrm{a} / \mathrm{c})$ decreased MTF to the buffer level or less in all experiments (Figure 3.1). Addition of anti tissue factor IgG (atf) 20 minutes prior to tissue factor measurement at room temperature completely suppressed MTF activity (Figure 3.1). These control experiments demonstrate that the assay specifically measures functional TF induced by plasma or LPS.

Incubation of monocytes A and monocytes B with individual plasma samples of healthy controls $(n=43)$ gave a median MTF activity of $1355 \mathrm{fM}$ (range 1044 to $1976 \mathrm{fM}$ ) and $1329 \mathrm{fM}$ (range 858 to $1951 \mathrm{fM}$ ) respectively. In these experiments the MTF activity of monocytes A was highly correlated to the MTF activity in monocytes $B: r=0.82(p<0.00001)$, showing that plasma inducing a high level of MTF in monocytes A was also inducing a high level of MTF in monocytes B (Figure 3.2). The high responders had a MTF activity of approximately $200 \%$ of the low responders.

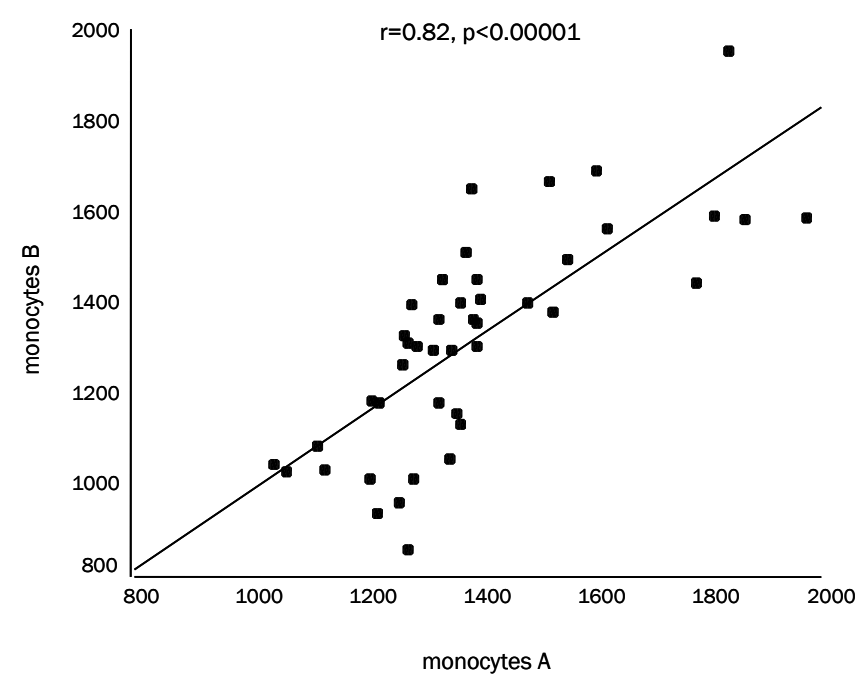

Figure 3.2 Correlation between MTF activity (in $\mathrm{fM}$ ) in monocytes A and MTF activity in monocytes $B$ after incubation with plasma of healthy controls $(n=43)$. This illustrates the plasma dependence of the high and low responder phenomenon. 
Incubation with plasma samples of individuals using coumarin anticoagulants $(\mathrm{n}=22)$ gave a median MTF activity of $1159 \mathrm{fM}$ (range 790 to $1887 \mathrm{fM}$ ) in monocytes A and $1193 \mathrm{fM}$ (range 731 to $1778 \mathrm{fM}$ ) in monocytes B (Figure 3.3).

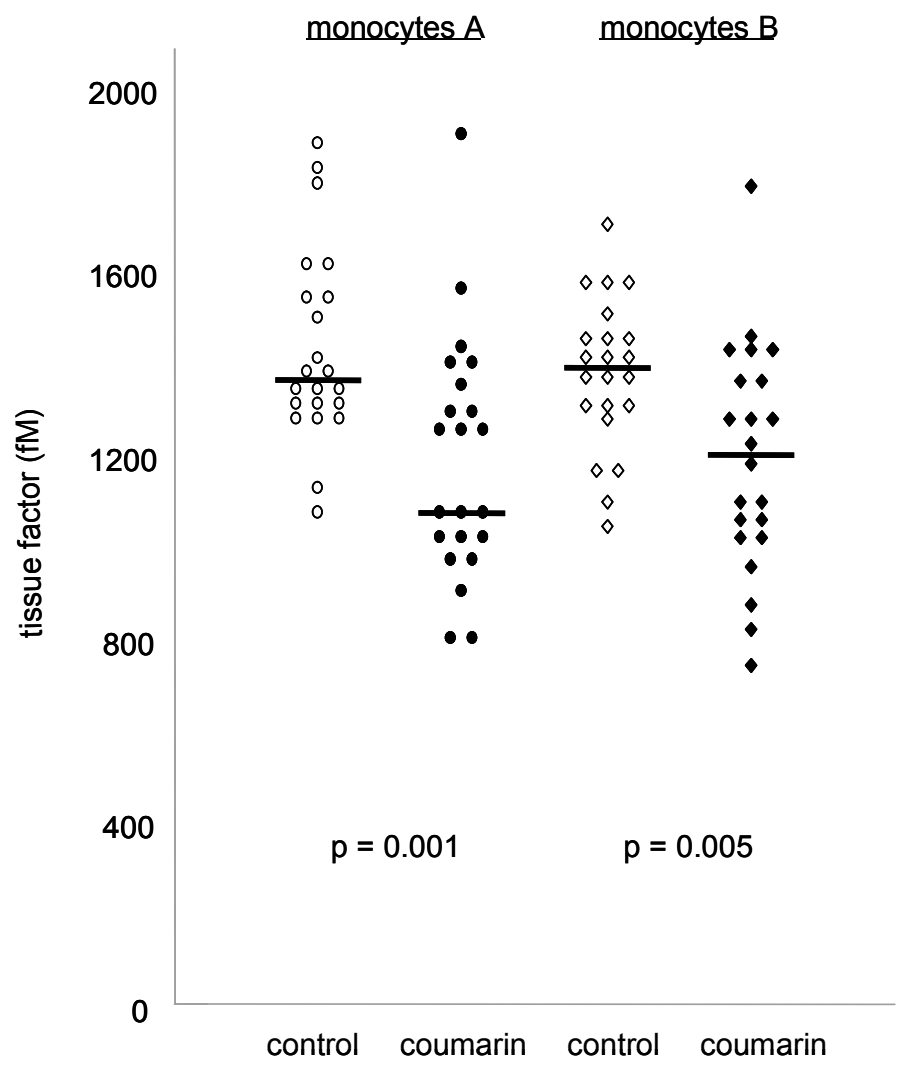

Figure 3.3 MTF activity (in $\mathrm{fM}$ ) in monocytes $A$ and in monocytes $B$ after incubation with plasma of individuals using coumarin oral anticoagulants (coumarin) compared with plasma of matched healthy controls (control) $(n=22)$. 
The MTF activity in monocytes A was once more highly correlated to the MTF activity in monocytes $B$ : $r=0.67(p=0.001)$ (Figure 3.4). The high responders again had a MTF activity of more than $200 \%$ of the low responders.
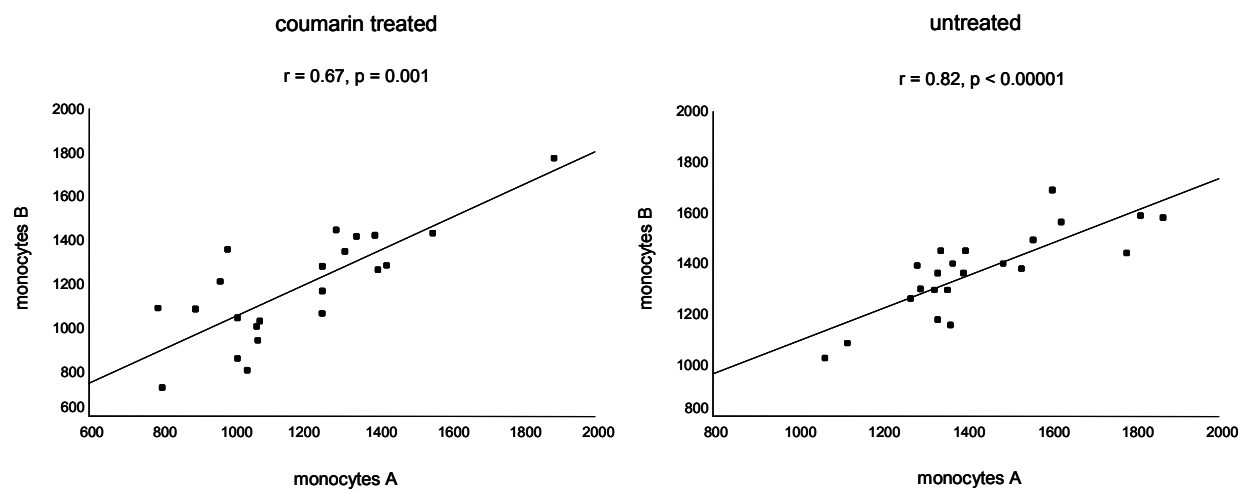

Figure 3.4 Correlation between MTF activity (in fM) in monocytes A and MTF activity in monocytes B after incubation with plasma of individuals using coumarin oral anticoagulants (coumarin treated) and incubation with plasma of matched healthy controls (untreated) $(n=22)$

The MTF activity in monocytes A and monocytes B after incubation with plasma samples of 14 individuals using coumarins was highly correlated with the MTF activity in the same monocytes after incubation with plasma of the same individuals four weeks after cessation of the coumarin therapy: $r=0.90$ $(p<0.0001)$ for monocytes $A$ and $r=0.85(p=0.0001)$ for monocytes $B$ (Figure 3.5). Thus, plasma of an individual inducing a low MTF activity during coumarin therapy also induces a low MTF activity after cessation of coumarin therapy. Furthermore, plasma of individuals inducing a high MTF activity during coumarin therapy retains this property after cessation of coumarin therapy. In monocytes B three of the fourteen individuals had a MTF activity that was higher during coumarin use (Figure 3.6).

Although not influencing the high and low responder phenomenon, coumarin plasma induced a MTF activity that was $15.2 \%(p=0.001)$ lower in monocytes $A$ and $14.0 \%(p=0.005)$ lower in monocytes B compared to normal plasma of matched healthy controls (Figure 3.3). This decrease was also found comparing plasma during and four weeks after coumarin use in the same individuals: $12.3 \%(p=0.001)$ in monocytes $A$ and $14.6 \%(p=0.09)$ in monocytes B. No correlation was found between MTF activity and the INR. 

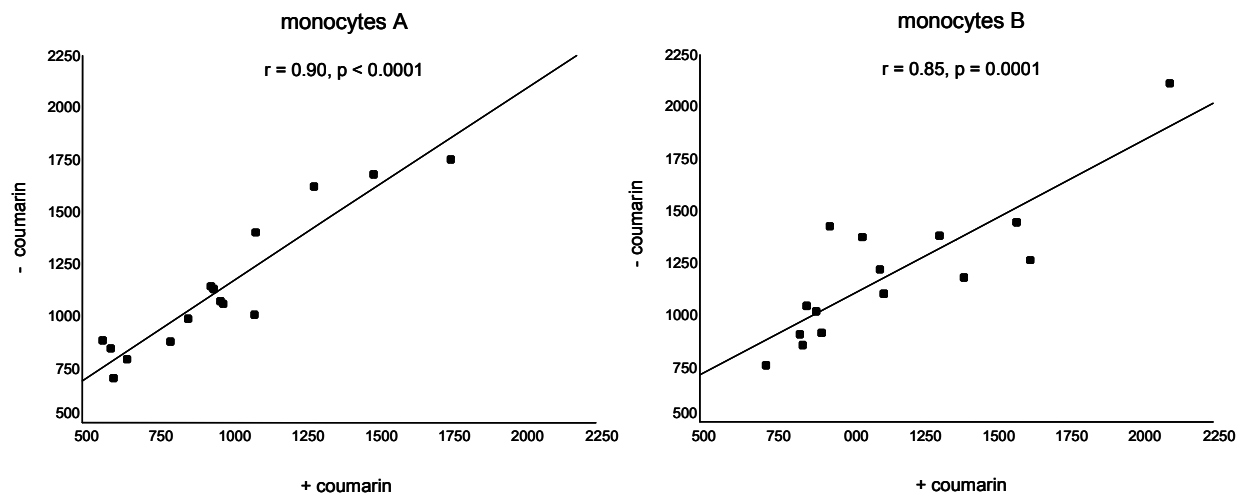

Figure 3.5 Correlation between MTF activity (in fM) in monocytes A and in monocytes B after incubation with plasma of individuals during use (+ coumarin) and four weeks after cessation (- coumarin) of coumarin anticoagulant therapy $(n=14)$.

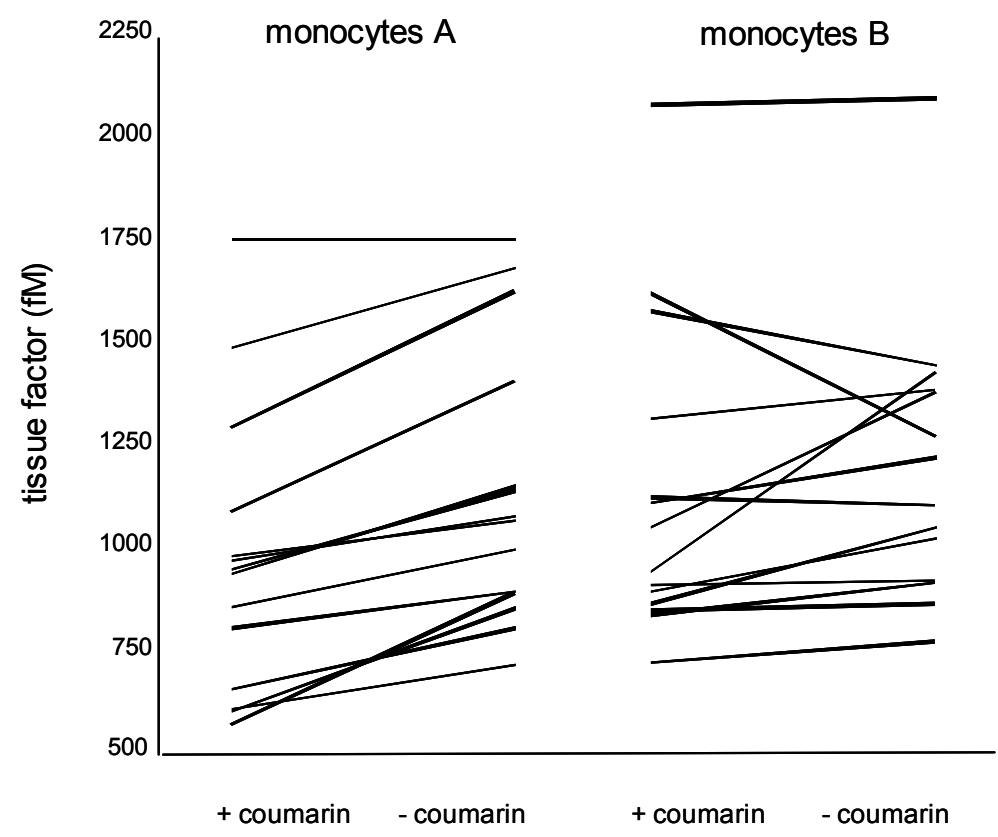

Figure 3.6 MTF activity (in fM) during use (+ coumarin) and four weeks after cessation (- coumarin) of coumarin anticoagulant therapy in monocytes $A$ and in monocytes $B(n=14)$. 


\section{Discussion}

This study demonstrates that in isolated human monocytes stimulated by adherence, in the absence of platelets, granulocytes and LPS, plasma regulates the MTF activity. The high and low responder phenomenon, upon stimulation monocytes of some individuals have a higher MTF activity than monocytes of others, is a result of differences in the plasma only, independent of granulocytes, platelets and LPS. Coumarin anticoagulant therapy does not influence the high and low responder phenomenon: high responders remain high responders and low responders remain low responders. It has been suggested that the high MTF response in individuals upon stimulation is associated with coronary artery disease and thrombosis ${ }^{6}$. This study demonstrates that plasma components might play a pivotal role.

Plasma components potentially involved in the MTF activity in this study include LPS, release products of platelets and granulocytes, coagulation factors, components influencing monocyte adherence, cytokines and many others ${ }^{5}$.

Plasma contains LPS binding protein, which greatly increases the sensitivity of monocytes to LPS, resulting in enhanced MTF activity ${ }^{16}$. The negative results of the Limulus assay and the addition of polymyxin B during the incubation period in all experiments exclude MTF activity induced by LPS in the plasma, the monocyte cultures or any of the reagents.

PF4, PAF and P-selectin enhanced MTF activity in LPS stimulated whole blood $^{8,11,12}$. Plasma collected after whole blood stimulation with collagen did not increase MTF activity in our plasma system depleted of platelets, granulocytes and LPS (data not shown). These data indicate that PF4, PAF and P-selectin increase MTF activity in a platelet, granulocyte and LPS dependent manner.

Serum and barium citrate absorbed plasma had an equal stimulatory effect in our plasma system as normal plasma (data not shown), as reported previously ${ }^{13}$. This indicates that a role of coagulation factors in the MTF activity is unlikely. The absence of any correlation between MTF and the INR in the individuals using coumarins is consistent with these observations. Coumarin plasma reduced MTF activity by 10 to $15 \%$, as in previous reports ${ }^{17-19}$, but did not influence the high and low responder phenomenon. Therefore we conclude that coagulation factors probably are not involved in the induction of MTF activity and the high responder phenomenon.

Adherence to surfaces is known to stimulate MTF activity, giving significant procoagulant activity after 1 to 3.5 hours $^{3,5}$. Although in vitro adherence of monocytes does not reflect the in vivo situation, it has been demonstrated that in vivo adherent monocytes are involved in a variety of pathophysiological processes $^{1,2}$. Therefore, stimulation of monocytes by adherence to an artificial 
surface in a plasma environment renders an interesting research model of in vivo adherent monocytes ${ }^{4}$. Plasma significantly increased the low level of MTF activity induced by adherence of the monocytes to the microtitre plate in HBSS buffer only (Figure 3.1). Plasma might facilitate adherence of monocytes to a surface thereby inducing increased MTF activity. Thus, differences between high and low responders might be caused by differences in adherence induced by plasma.

Human cytokines are known to inhibit or stimulate MTF activity. MTF activity is inhibited by interleukin (IL)-4, IL-10 and IL-13 and stimulated by IL-1, IL-6 and IL- $8^{20-23}$. In an individual plasma a balance of stimulating and inhibiting cytokines might regulate the level of MTF activity. Thus, the high and low responder phenomenon could be the result of dominating MTF stimulating respectively inhibiting cytokines.

Many other factors have been reported to influence MTF activity in vitro and in vivo $^{5}$. The precise role of these factors in the plasma determined MTF activity and in the high and low responder phenomenon is complex and largely unknown. Interestingly, families have been observed with a high incidence of myocardial infarction and postoperative thrombosis associated with a high MTF response $^{6}$. These observations suggest that the high and low responder phenomenon is an inherited trait. This study demonstrates that the inherited basis for the high and low responder phenomenon might be in the plasma.

In conclusion, plasma is an important regulator of the MTF activity and the high and low responder phenomenon. MTF activity is increased in several pathological conditions ${ }^{1,2,24-28}$ and a high MTF response in individuals upon stimulation has been associated with coronary artery disease and thrombosis ${ }^{6}$. Plasma samples of patients with these conditions are currently being evaluated. Changes in the plasma in these pathological conditions by medical intervention could influence MTF activity and might therefore be clinically important. 


\section{References}

1. Semeraro N, Colucci M. Tissue factor in health and disease. Thromb Haemost 1997;78:759-64.

2. Østerud B. Tissue factor: a complex biological role. Thromb Haemost 1997;78: 755-8.

3. Van Ginkel CJW, van Aken WG, Oh JIH, Vreeken J. Stimulation of monocyte procoagulant activity by adherence to different surfaces. $\mathrm{Br} J$ Haematol 1977;37:35-45.

4. Lefkowith JB, Lennartz MR, Rogers M, Morrison AR, Brown EJ. Phospholipase activation during monocyte adherence and spreading. J Immunol 1992;149: 1729-35.

5. Østerud B. Tissue factor expression by monocytes: regulation and pathophysiological roles. Blood Coag Fibrinol 1998;9(suppl 1):S9-S14.

6. Østerud B. The high responder phenomenon: Enhancement of LPS induced tissue factor activity in monocytes by platelets and granulocytes. Platelets 1995;6:119-25.

7. Niemetz J, Marcus AJ. The stimulatory effect of platelets and platelet membranes on the procoagulant activity of leukocytes. J Clin Invest 1974;54:1437-43.

8. Halvorsen H, Olsen JO, Østerud B. Granulocytes enhance LPS-induced tissue factor activity in monocytes via an interaction with platelets. J Leukoc Biol 1993;54:275-82.

9. Amirkhosravi A, Alexander M, May K, Francis DA, Warnes G, Biggerstaff J, Francis $\mathrm{JL}$. The importance of platelets in the expression of monocyte tissue factor antigen measured by a new whole blood flow cytometric assay. Thromb Haemost 1996;75:87-95.

10. Østerud B, Olsen JO, Wilsgård L. The role of arachidonic acid release and lipoxygenase pathway in lipopolysaccharide-induced thromboplastin activity in monocytes. Blood Coag Fibrinol 1990;1:41-6.

11. Sissener Engstad C, Lia K, Rekdal $\varnothing$, Olsen JO, Østerud B. A novel biological effect of platelet factor 4 (PF4): enhancement of LPS-induced tissue factor activity in monocytes. J Leukoc Biol 1995;58:575-81.

12. Østerud B. Platelet activating factor enhancement of lipopolysaccharide-induced tissue factor activity in monocytes: requirement of platelets and granulocytes. J Leukoc Biol 1992;51:462-5.

13. Edwards RL, Perla D. The effect of serum on monocyte tissue factor generation. Blood 1984;64:707-14

14. Plas A, de Witte $T$, Wessels $H$, Haanen $C$. A new multichamber counterflow centrifugation rotor with high-separation capacity and versatile potentials. Exp Hematol 1988;16:355-9.

15. Sissener Engstad C, Gutteberg TJ, Østerud B. Modulation of blood cell activation by four commonly used anticoagulants. Thromb Haemost 1997;77:690-7.

16. Steinemann S, Ulevitch RJ, Mackman N. Role of the lipopolysaccharide (LPS)binding protein/CD14 pathway in LPS induction of tissue factor expression in monocytic cells. Arterioscler Thromb 1994;14:1202-9.

17. Edwards RL, Rickles FR. Delayed hypersensitivity in man: effects of systemic anticoagulation. Science 1978:200:541-3.

18. Edwards RL, Rickles FR, Cronlund M. Abnormalities of blood coagulation in patients with cancer. Mononuclear cell tissue factor generation. J Lab Clin Med 1981;98:917-28. 
19. Edwards RL, Schreiber E, Brande W. The effect of sodium warfarin on rabbit monocyte tissue factor expression. Thromb Res 1986;42:125-37.

20. Schwager I, Jungi TW. Effect of human recombinant cytokines on the induction of macrophage procoagulant activity. Blood 1994;83:152-60.

21. Lindmark E, Tenno T, Chen J, Siegbahn A. IL-10 inhibits LPS-induced human monocyte tissue factor expression in whole blood. $\mathrm{Br} \mathrm{J}$ Haematol 1998;102: 597-604.

22. Ernofsson M, Tenno T, Siegbahn A. Inhibition of tissue factor surface expression in human peripheral blood monocytes exposed to cytokines. $\mathrm{Br} \mathrm{J}$ Haematol 1996;95:249-57.

23. Neumann FJ, Ott I, Marx N, Luther T, Kenngott S, Gawaz M, Kotzsch M, Schomig A. Effect of human recombinant interleukin-6 and interleukin-8 on monocyte procoagulant activity. Arterioscler Thromb Vasc Biol 1997;17:3399-405.

24. Wilcox JN, Smith KM, Schwartz SM, Gordon D. Localization of tissue factor in the normal vessel wall and in the atherosclerotic plaque. Proc Natl Acad Sci USA 1989;86:2839-43.

25. Tipping PG, Malliaros J, Holdsworth SR. Procoagulant activity expression by macrophages from atheromatous plaques. Atherosclerosis 1989;79:237-43.

26. Semeraro N, Colucci $M$. Changes in the coagulation-fibrinolysis balance of endothelial cells and mononuclear phagocytes: role in disseminated intravascular coagulation associated with infectious diseases. Int J Clin Lab Res 1992;21: 214-20.

27. Zhang Y, Deng Y, Luther T, Muller M, Ziegler R, Waldherr R, Stern DM, Nawroth PP. Tissue factor controls the balance of angiogenic and antiangiogenic properties of tumor cells in mice. J Clin Invest 1994;94:1320-7.

28. Morgan D, Edwards RL, Rickles FR. Monocyte procoagulant activity as a peripheral marker of clotting activation in cancer patients. Haemostasis 1988;18:55-65. 


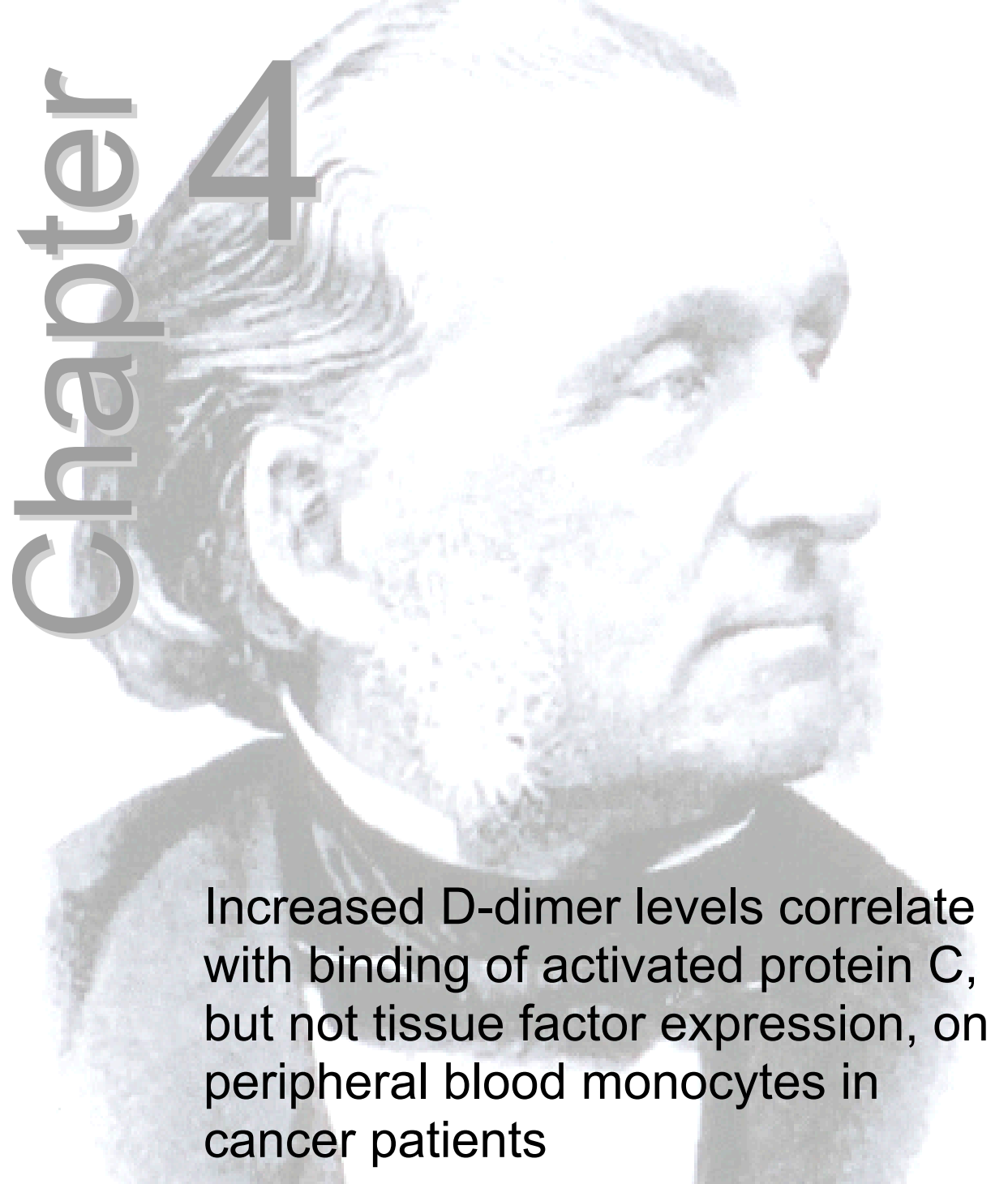

Marten R Nijziel, René van Oerle, Elisabeth CM van Pampus, Henrica CW de Vet, Harry FP Hillen, Karly Hamulyák

Am J Haematol 2000:64:282-286 


\section{Summary}

Monocyte tissue factor expression is supposed to play an important role in the hypercoagulability of blood in cancer patients. The relation between coagulation parameters and the expression of monocyte membrane proteins involved in hemostasis or monocyte activation was studied in 21 patients with a disseminated malignancy and 21 age and sex matched healthy controls.

In the cancer patient group no increase of monocyte tissue factor expression was found ( 8.4 vs. $7.8 \% ; p=0.83$ ), but a significant increase of monocyte bound activated protein C (APC) (28.8 vs. $13.4 \% ; p=0.009)$ and monocyte CD16 expression (34.5 vs. $27.0 \% ; p=0.007)$ was observed. There was also a significant increase of D-dimers (2.0 vs. $0.2 \mu \mathrm{g} / \mathrm{ml} ; p=0.001)$, a decrease of antithrombin ( 83.5 vs. $102.0 \% ; p=0.004)$, but no increase of TAT-complexes ( 1.7 vs. $1.5 \mu \mathrm{g} / \mathrm{l} ; \mathrm{p}=0.38)$ and factor $\mathrm{VII}_{\mathrm{a}}(68.5 \mathrm{vs.} 75.0 \%$; $\mathrm{p}=0.52)$. The increase of D-dimers was significantly correlated with the monocyte APC ( $r=0.60$; $p=0.005)$, but not with monocyte tissue factor levels $(r=-0.22 ; p=0.35)$ or TATcomplexes $(r=0.12 ; p=0.60)$.

These results reflect a local rather than systemic thrombin and fibrin formation. It is suggested that the APC formed locally enters the circulation and binds to peripheral blood monocytes. APC bound on monocytes is known to inhibit monocyte cytokine production and might therefore be involved in regulatory responses of monocytes in cancer patients. 


\section{Introduction}

Activation of the hemostatic system, intravascular as well as extravascular, is a well-known but poorly understood phenomenon in cancer patients ${ }^{1-3}$. In particular symptomatic and recurrent episodes of venous thromboembolism in these patients are common ${ }^{4,5}$. Tumor cells activate the hemostatic system by producing tissue factor or other procoagulant proteins, such as cancer procoagulant $(\mathrm{CP})^{6}$. Tumor cells also induce procoagulant activity of other cells ${ }^{1,7}$. Of interest is the fact that tumor induced tissue factor expression on the monocyte membrane may play an important role in the hypercoagulability of cancer patients ${ }^{8,9}$. Monocytes and the hemostatic system are also involved in tumor cell growth and angiogenesis ${ }^{10-13}$.

In this study we examined the relation between activation of the hemostatic system and the expression of monocyte membrane proteins in cancer patients. We studied those membrane proteins involved in hemostasis or in monocyte activation. A high tumor load and aggressive tumor behavior are known to produce enhanced activation ${ }^{4,5}$. We therefore studied two extremes of the spectrum, namely cancer patients with advanced disease and healthy controls.

\section{Materials and methods}

\section{Patients}

Twenty-one patients with a disseminated malignancy and 21 age and sex matched healthy volunteers were included in the study. Only patients not using anticoagulant therapy and without clinical signs of arterial or venous thromboembolism were included. The patients had tumors of the breast (10), digestive tract (7), pancreas (1), testis (1), thyroid (1) and bladder (1). Metastases were in lymph nodes (9), liver (6), pleura (3), lung (3), bone (3), skin (3) and peritoneum (1). Seven patients had metastases at multiple locations. Blood was collected prior to (renewed) chemotherapy, radiotherapy and surgical intervention. Patients had no signs of concomitant infection. Last chemotherapy (five patients) was at least one year previously. The healthy controls were not allowed to use any medication, including oral contraceptives. The mean routine hematological parameters (hemoglobin, hematocrit, platelets, leukocyte count and differential) were within the normal range in both groups. All patients and volunteers agreed to participate in the study following informed consent. The study was approved by the Ethical Review Committee of the University Hospital Maastricht. The baseline characteristics of study population are shown in Table 4.1. 
Table 4.1 Characteristics the study population (mean).

\begin{tabular}{lccl}
\hline & $\begin{array}{c}\text { Patients } \\
(\mathrm{n}=21)\end{array}$ & $\begin{array}{c}\text { Controls } \\
(\mathrm{n}=21)\end{array}$ & P value \\
\hline Sex (male/female) & $3 / 18$ & $5 / 16$ & $\mathrm{n} . \mathrm{s}$. \\
Age (years) mean & 54.8 & 48.2 & 0.19 \\
range & $19-83$ & $32-82$ & \\
Smoking/Non-smoking & $4 / 17$ & $6 / 15$ & n.s. \\
Hemoglobin $(\mathrm{mmol} / \mathrm{l})$ & 7.8 & 8.5 & 0.02 \\
Hematocrit $(\mathrm{l} / \mathrm{l})$ & 0.38 & 0.40 & 0.05 \\
Platelets $\left(10^{9} / \mathrm{l}\right)$ & 232 & 251 & 0.24 \\
Leukocyte count $\left(10^{9} / \mathrm{l}\right)$ & 8.3 & 6.6 & 0.05 \\
Neutrophils $\left(10^{9} / \mathrm{l}\right)$ & 6.1 & 3.9 & 0.007 \\
Lymphocytes $\left(10^{9} / \mathrm{l}\right)$ & 1.4 & 1.9 & 0.02 \\
Eosinophils $\left(10^{9} / \mathrm{l}\right)$ & 0.1 & 0.2 & 0.14 \\
Basophils $\left(10^{9} / \mathrm{l}\right)$ & 0.1 & 0.1 & 1.0 \\
Monocytes $\left(10^{9} / \mathrm{l}\right)$ & 0.6 & 0.5 & 0.31 \\
\hline
\end{tabular}

\section{Blood collection and preparation}

From the antecubital vein $25 \mathrm{ml}$ of blood was collected with a Strauß Kanüle $1,2 \times 43 \mathrm{~mm}$ (Lameris, the Netherlands) without venous stasis. The first $3 \mathrm{ml}$ were collected into a $5 \mathrm{ml}$ plastic tube (Sarstedt, Germany) and processed to serum, by centrifugation (five minutes, $4000 \mathrm{rpm}$ ) after clotting at $37^{\circ} \mathrm{C}$. The next $18 \mathrm{ml}$ were collected into two $10 \mathrm{ml}$ plastic tubes $(16,8 \times 100 \mathrm{~mm}, 164180$, Greiner, Germany) containing $1 \mathrm{ml}$ of sodium citrate $3.8 \%$ each. Citrated platelet poor plasma was made using two centrifuge steps (five minutes 4000 $\mathrm{rpm}$ and ten minutes $11000 \mathrm{rpm}$ ). The samples were processed within 30 minutes after the blood collection. Serum and plasma were stored at $-70^{\circ} \mathrm{C}$ in aliquots of $500 \mu \mathrm{l}$ until analysis. The last $4 \mathrm{ml}$ were collected into a plastic tube containing 7.2 mg EDTA (K2) (Becton Dickinson Europe, France). This blood was processed directly for flow cytometric analysis.

\section{Coagulation parameters}

All measurements of coagulation parameters were performed in citrated platelet poor plasma. The activated partial thromboplastin time (APTT), prothrombin time (PT) and fibrinogen were measured on a STA Analyzer (CA 5050720) (Boehringer Mannheim/ Diagnostica Stago) according to standard laboratory procedures. D-dimers were determined using the STA LIA-test ${ }^{\circledR}$ D-DI (Diagnostica Stago, France) according to the manufacturers instructions. Thrombin-antithrombin complexes (TAT) were measured by an ELISA using capture antibody cat. no. SAHT-AP and conjugate cat. no. SAAT-APHRP from ERL purchased from Kordia Laboratory Supplies. Antithrombin was measured using Coamatic ${ }^{\circledR}$ antithrombin (Chromogenix, Sweden). For factor $\mathrm{VII}_{\mathrm{c}}$ we used 
a one-stage factor coagulation assay with factor VII deficient plasma purchased from Organon, the Netherlands. Factor $\mathrm{VII}_{\mathrm{a}}$ was measured using Staclot ${ }^{\circledR} \mathrm{VIIa-}$ rTF (cat. no. 00281, Diagnostica Stago, France). Von Willebrand Factor Antigen $\left(\mathrm{vWF}_{\mathrm{Ag}}\right)$ was measured by ELISA using capture antibody A082 and conjugate P226 both from Dakopatts a/s, Denmark. Tissue Factor Pathway Inhibitor (TFPI) was determined using a chromogenic assay according to Sandset with minor modifications ${ }^{14}$. Plasminogen Activator Inhibitor type 1 (PAI-1) activity was measured using the Spectrolyse ${ }^{\circledR} / \mathrm{pL}$ PAI chromogenic assay kit (Biopool, Sweden).

\section{Flow cytometric analysis}

Flow cytometric analysis was performed on a FACSCalibur flow cytometer (Becton Dickinson). Mouse anti-human monoclonal antibodies (mAbs) against CD14 (LPS-receptor), CD16 (FC $\gamma$ receptor III), CD71 (transferrin receptor), CD87 (urokinase plasminogen activator receptor, uPA-R), protein C, thrombomodulin, coagulation factor $X$ and tissue factor were used. The CD14 (IgG2a; art. no. M1430), CD16 (IgG2a; M1604) and CD71 (IgG1; M2162) FITCconjugated mAbs were purchased from CLB (Amsterdam, the Netherlands).

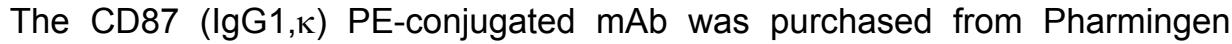
(Hamburg, Germany, cat. no. 33885X) and the CD14 (IgG2b) PE-conjugated mAb from Becton Dickinson (San Jose, USA, cat. no. 347497). The mAbs

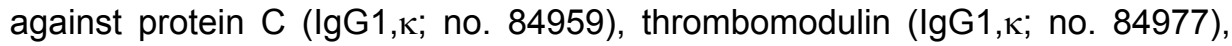
factor X (IgG2a; ERL A119) and tissue factor (IgG1; ERL A135L) were purchased from Kordia Laboratory Supplies (Leiden, the Netherlands). These were unconjugated mAbs. By ELISA it was demonstrated that the protein $C$ mAb 84959 recognizes protein $C$ and activated protein $C$ (APC) equally well (own experiments, data not shown). Protein $C$ binds calcium-dependently to the phospholipid surface of activated mononuclear cells, APC calciumindependently to a specific receptor ${ }^{15,16}$. Because the experiments were performed in EDTA anticoagulated blood with a double washing step prior to incubation with the protein $\mathrm{C}$ mAb, it is impossible that plasma protein $\mathrm{C}$ was bound to the monocyte during the analysis procedure. Protein $\mathrm{C}$, already bound in vivo, will also be eluted from the monocyte membrane in EDTA anticoagulated blood. It was, therefore, concluded that the protein $\mathrm{C}$ measured on the monocyte membrane was in fact the result of the in vivo calciumindependent binding of APC.

All incubation steps were done in plastic $12 \times 75 \mathrm{~mm}$ tubes (Falcon) purchased from Becton Dickinson. All centrifugation steps were for five minutes at $2000 \mathrm{rpm}$. In all procedures mouse isotype negative controls (CLB, Amsterdam, the Netherlands) were measured. First 2 ml EDTA anticoagulated whole blood was incubated with $40 \mu \mathrm{l}$ Fc-receptor Blocking Reagent (human 
IgG, no. 599-01, Miltenyi Biotec $\mathrm{GmbH}$, Bergisch Gladbach, Germany) for ten minutes at $4^{\circ} \mathrm{C}$ in the dark. Then samples of $100 \mu \mathrm{l} \mathrm{Fc-receptor} \mathrm{blocked} \mathrm{whole}$ blood were incubated for 30 minutes at $4^{\circ} \mathrm{C}$ in the dark with $10 \mu$ of a FITCconjugated mAb and $5 \mu \mathrm{l}$ of the CD14 PE mAb. For the CD87 PE mAb (10 $\mu \mathrm{l})$ we used the CD14 FITC mAb $(10 \mu \mathrm{l})$. The rest of the Fc-receptor blocked whole blood was washed twice with $3 \mathrm{ml}$ of PBN (PBS containing $0.1 \%$ sodiumazide and $0.1 \%$ bovine serum albumin) to wash out target antigens present in the plasma. Samples of $125 \mu \mathrm{l}$ of this washed Fc-receptor blocked whole blood were incubated for 30 minutes at $4^{\circ} \mathrm{C}$ in the dark with $10 \mu \mathrm{l}$ of the respective non-FITC non-PE conjugated mAbs. In this series we performed a second incubation step with $10 \mu \mathrm{l}$ FITC-conjugated goat anti-mouse polyclonal antibodies $\left(\mathrm{F}(\mathrm{ab})_{2}\right)_{2}$ fragments; code G26M17F, CLB) and a third incubation with $5 \mu \mathrm{l}$ of the PE-conjugated CD14 mAb, both for 30 minutes at $4^{\circ} \mathrm{C}$ in the dark. After every incubation step cells were washed twice with $3 \mathrm{ml}$ of PBN. Finally red cells were lysed with diluted Becton Dickinson FACS Lysing Solution 349202 according to the standard procedure. After washing twice with $3 \mathrm{ml}$ of PBN, the cells were resuspended in $300 \mu \mathrm{l}$ of PBN and stored for maximally two hours at $4^{\circ} \mathrm{C}$ prior to flow cytometric analysis.

Data acquisition and analysis were performed using CELLQuest Becton Dickinson software. Monocytes were identified using the CD14 FITC- or PEconjugated mAb and the forward and sideward light scatter pattern. 5000 CD14 positive cells were counted. The negative and positive delineator was positioned by determining $5 \%$ background staining on the isotype control fluorescence. Then the percentage of the FITC- or PE (CD87) positive events was measured in the monocyte gate.

\section{Statistics}

The data were analyzed using SPSS for Windows version 8.0 (SPSS Inc., Chicago, USA). The routine hematological parameters showed a normal distribution and were analyzed with the independent-samples T-test. Results are given as means. Many of the other variables did not show a normal distribution. Nonparametric tests for independent samples were, therefore, used. To compare the variables in the patient group and the controls a MannWhitney U-test was performed. The differences were considered significant at $p<0.05$. Here results are given as medians. Spearman correlation coefficients were calculated to examine the relation between the various parameters. 


\section{Results}

In the cancer patient group compared to the healthy controls there was no increase of monocyte tissue factor expression (8.4 versus $7.8 \% ; p=0.83$ ). A significant increase of monocyte bound APC (28.8 versus $13.4 \% ; p=0.009)$ and monocyte CD16 expression (34.5 versus $27.0 \%$; $p=0.007$ ) was, however, found (Table 4.2 and Figure 4.1).

Table 4.2 Flow cytometric analysis: \% positive cells in CD14 positive monocytes (median).

\begin{tabular}{lccl}
\hline & $\begin{array}{c}\text { Patients } \\
(\mathrm{n}=21)\end{array}$ & $\begin{array}{c}\text { Controls } \\
(\mathrm{n}=21)\end{array}$ & P value \\
\hline CD16 & 34.5 & 27.0 & 0.007 \\
CD71 & 84.6 & 78.6 & 0.31 \\
CD87 & 46.6 & 28.1 & 0.12 \\
Thrombomodulin & 77.2 & 77.3 & 0.57 \\
APC & 28.8 & 13.4 & 0.009 \\
Factor X & 10.0 & 9.3 & 0.47 \\
Tissue factor & 8.4 & 7.8 & 0.83 \\
\hline
\end{tabular}
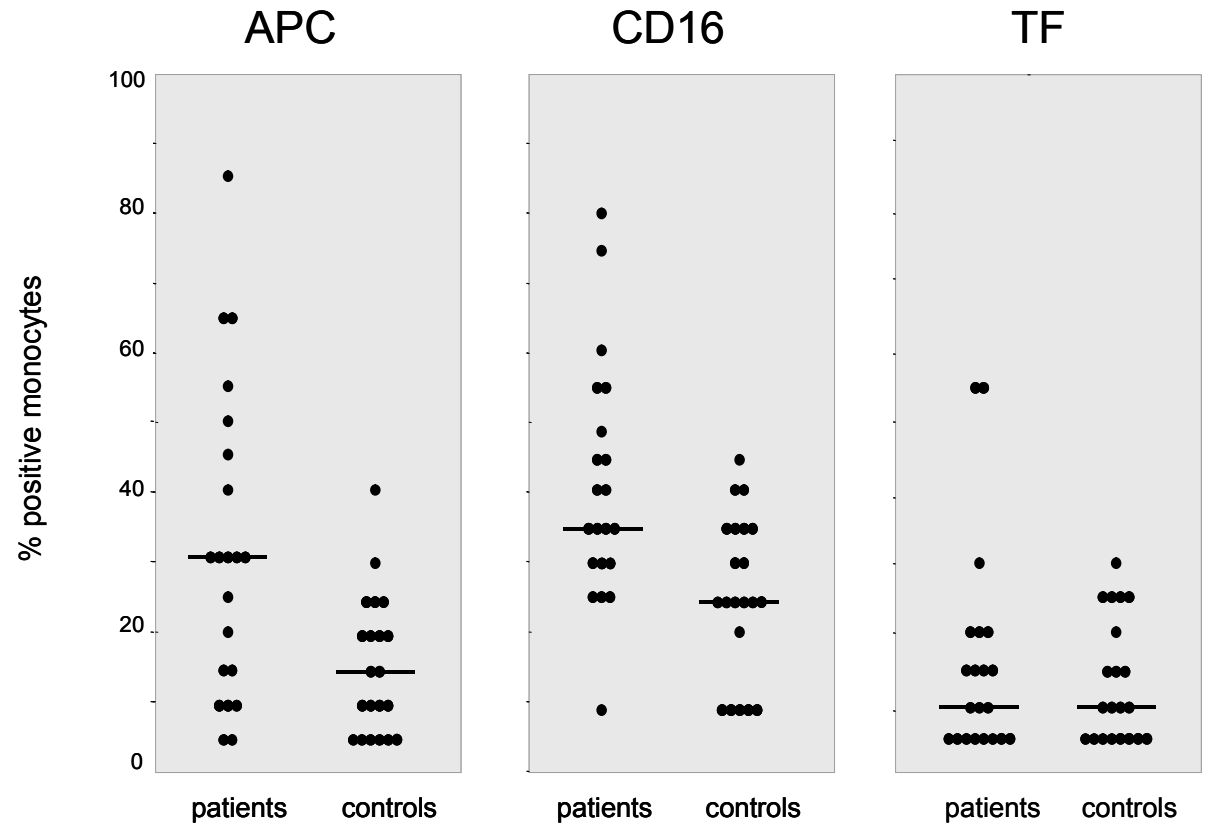

Figure 4.1 APC, CD16 and TF on peripheral blood monocytes in cancer patients and controls (in $\%$ positive monocytes). 
The cancer patients had a significant increase of D-dimers $(2.0 \mathrm{vs} .0 .2 \mu \mathrm{g} / \mathrm{ml}$; $p=0.001$ ), a significant decrease of antithrombin (83.5 vs. $102.0 \% ; p=0.004$ ), but no significant increase of TAT-complexes (1.7 vs. $1.5 \mu \mathrm{g} / \mathrm{l} ; \mathrm{p}=0.38$ ). Other significant elevations were observed in fibrinogen ( $3.8 \mathrm{vs} .3 .0 \mathrm{~g} / \mathrm{l} ; \mathrm{p}=0.01)$ and $\mathrm{vWF}_{\mathrm{Ag}}(165.5$ vs. $81.5 \%$; $\mathrm{p}=0.02)$, but not in factor $\mathrm{VII}_{\mathrm{a}}(68.5$ vs. $75.0 \mathrm{mU} / \mathrm{ml}$; $\mathrm{p}=0.52)$ (Table 4.3).

Table 4.3 Coagulation parameters (median)

\begin{tabular}{lccc}
\hline & $\begin{array}{c}\text { Patients } \\
(\mathrm{n}=21)\end{array}$ & $\begin{array}{c}\text { Controls } \\
(\mathrm{n}=21)\end{array}$ & P value \\
\hline APTT $(\mathrm{s})$ & 27.1 & 28.3 & 0.03 \\
PT $(\mathrm{s})$ & 13.5 & 12.7 & 0.02 \\
Fibrinogen $(\mathrm{g} / \mathrm{l})$ & 3.8 & 3.0 & 0.01 \\
D-dimers $(\mu \mathrm{g} / \mathrm{ml})$ & 2.0 & 0.2 & 0.001 \\
TAT $(\mu \mathrm{g} / \mathrm{l})$ & 1.7 & 1.5 & 0.38 \\
Antithrombin $(\%)$ & 83.5 & 102.0 & 0.004 \\
Factor VII $(\%)$ & 87.5 & 101.5 & 0.10 \\
Factor $\mathrm{VII}(\mathrm{mU} / \mathrm{ml})$ & 68.5 & 75.0 & 0.52 \\
VWFF $_{\mathrm{Ag}}(\%)$ & 165.5 & 81.5 & 0.02 \\
TFPI $_{(\%)}$ & 104.5 & 99.0 & 0.21 \\
PAl-1 $(\mathrm{U} / \mathrm{ml})$ & 12.6 & 10.4 & 0.33 \\
\hline
\end{tabular}

Importantly, no differences were found in the absolute number of monocytes between patients and controls (0.6 vs. $\left.0.510^{9} / l ; p=0.31\right)$. Patients had significantly lower levels of hemoglobin ( 7.8 vs. $8.5 \mathrm{mmol} / \mathrm{l} ; \mathrm{p}=0.02)$ and lymphocytes ( 1.4 vs. $1.910^{9} /$; $\left.p=0.02\right)$, and significantly higher neutrophils (8.3 vs. $6.610^{9} /$; $p=0.007$ ) (Table 4.1).

The increase of $D$-dimers in the patient group was significantly correlated with the monocyte bound APC ( $r=0.60 ; p=0.005)$ (Figure 4.2) and not with monocyte tissue factor expression $(r=-0.22 ; p=0.35)$ or TAT-complexes $(r=0.12 ; p=0.60)$. There was no correlation between any of the coagulation parameters and increased monocyte CD16 expression. 


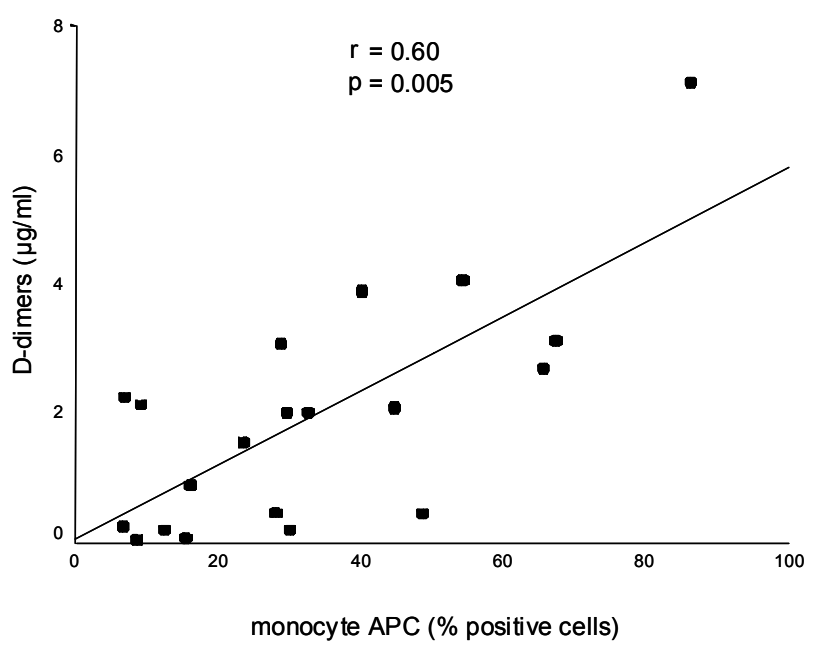

Figure 4.2 Correlation between D-dimers in plasma and monocyte APC in cancer patients.

\section{Discussion}

Interestingly, this study shows elevated D-dimer levels without an increase of monocyte tissue factor expression, TAT-complexes and factor $\mathrm{VII}_{\mathrm{a}}$ in patients with a disseminated cancer compared to age and sex matched healthy controls. In contrast to other studies ${ }^{8,9}$ that showed significant differences in tissue factor expression on monocytes between cancer patients and normals in vitro in isolated monocytes and monocyte cell cultures after overnight incubation or stimulation with LPS, we did a direct work-up of unstimulated whole blood. This is a better reflection of the in vivo situation ${ }^{17}$. The absence of elevated levels of factor $\mathrm{VII}_{\mathrm{a}}$ also indicates that in this cancer patient group there is no extrinsic pathway activation, as previously observed ${ }^{18,19}$.

Increased D-dimer levels in the patient group indicate thrombin and crosslinked fibrin formation. The absence of increased TAT-complexes in the peripheral blood suggests a local rather than systemic production of thrombin and cross-linked fibrin. This is in line with reports of localized extravascular fibrin deposition around tumors ${ }^{3}$. The plasma levels of D-dimers and TATcomplexes are determined by both production rate and clearance rate from the circulation. The relative contribution of an abnormal clearance rate in patients with a disseminated malignancy is unknown.

The increased D-dimer levels are strongly correlated with elevated levels of APC bound on peripheral blood monocytes. Because of the absence of 
systemic thrombin generation and hence APC production, this finding suggests that APC formed during local thrombin formation enters the circulation and binds to its specific receptor on monocytes. Indeed, additional experiments in vitro have demonstrated that addition of APC to both EDTA and heparin anticoagulated blood gives a similar increase in monocyte bound APC. The increase in bound APC in heparinized blood did not change after addition of EDTA. Protein C activation by its activator Protac ${ }^{\circledR}$ resulted, in EDTA as well as in heparinized blood, in comparable increases in monocyte APC levels (own experiments, data not shown).

APC bound on monocytes inhibits the intracellular calcium signaling and regulates several monocyte functions, including monocyte cytokine production and mononuclear adhesion and phagocytosis ${ }^{15,16}$. In two studies it was demonstrated that addition of APC to isolated human monocytes in vitro inhibits production of TNF- $\alpha$, IL- $1 \beta$ and IL- $6^{16,20}$. Increased levels of TNF- $\alpha$, IL$1 \beta$ and IL-6 have been reported in cancer patients. It was postulated that these contribute to cancer related hypercoagulability ${ }^{21-24}$. By inhibiting the production of these cytokines, APC formed in extravascular thrombin formation might have an intravascular anticoagulant effect. Modulation of these cytokines will also have immunoregulatory effects. Thus, APC bound on peripheral monocytes might play a regulatory role in cancer patients.

CD16 positive monocytes are increased in cancer patients and differentiate to CD16 positive macrophages, which have tumor-infiltrating capacities ${ }^{25-27}$. A role of activation of coagulation in this phenomenon is unlikely, because of the complete absence of correlation with any of the coagulation parameters.

In conclusion, this study shows that in cancer patients increased D-dimer levels do not correlate with tissue factor expression on peripheral blood monocytes. They reflect local rather than systemic thrombin and fibrin formation. We hypothesize that locally formed APC enters the circulation and binds to peripheral blood monocytes. APC bound on monocytes is known to inhibit monocyte cytokine production and might therefore be involved in regulatory responses of monocytes in cancer patients. 


\section{References}

1. Green KB, Silverstein RL. Hypercoagulability in cancer. Hematol Oncol Clin North Am 1996;10(2):499-530.

2. Goad KE, Gralnick HR. Coagulation disorders in cancer. Hematol Oncol Clin North Am 1996;10(2):457-84.

3. Francis $\mathrm{JL}$, Biggerstaff $\mathrm{J}$, Amirkhosravi A. Hemostasis and malignancy. Semin Thromb Hemost 1998;24(2):93-109.

4. Sörensen HT, Mellemkjaer L, Steffensen FH, Olsen JH, Nielsen GL. The risk of a diagnosis of cancer after primary deep venous thrombosis or pulmonary embolism. N Engl J Med 1998;338:1169-73.

5. Baron JA, Gridley G, Weiderpass E, Nyren O, Linet M. Venous thromboembolism and cancer. Lancet 1998;351:1077-80.

6. Gordon SG, Mielicki WP. Cancer procoagulant: a factor $X$ activator, tumor marker and growth factor from malignant tissue. Blood Coagul Fibrinolysis 1997;8:73-86

7. Edwards RL, Rickles FR. The role of leukocytes in the activation of blood coagulation. Semin Hemat 1992;29(3):202-12.

8. Edwards RL, Rickles FR, Cronlund M. Abnormalities of blood coagulation in patients with cancer. Mononuclear cell tissue factor generation. J Lab Clin Med 1981;98:917-28.

9. Morgan D, Edwards RL, Rickles FR. Monocyte procoagulant activity as a peripheral marker of clotting activation in cancer patients. Haemostasis 1988;18(1):55-65.

10. Zhang Y, Deng Y, Luther T, Muller M, Ziegler R, Waldherr R, Stern DM, Nawroth $\mathrm{PP}$. Tissue factor controls the balance of angiogenic and antiangiogenic properties of tumor cells in mice. J Clin Invest 1994;94:1320-7.

11. Arras M, Ito WD, Scholz D, Winkler B, Schaper J, Schaper W. Monocyte activation in angiogenesis and collateral growth in the rabbit hindlimp. J Clin Invest 1998;101(1):40-50.

12. Zacharski LR, Ornstein DL. Heparin and cancer. Thromb Haemost 1998;80:10-23.

13. Shoji M, Hancock WW, Abe K, Micko C, Casper KA, Baine RM, Wilcox JN, Danave I, Dillehay DL, Matthews E, Contrino J, Morrissey JH, Gordon S, Edgington TS, Kudryk B, Keutzer DL, Rickles FR. Activation of coagulation and angiogenesis in cancer. Immunohistochemical Localization in situ of clotting proteins and vascular endothelial growth factor in human cancer. Am J Pathol 1998;152:399-411.

14. Sandset PM, Abildgaard U, Pettersen M. A sensitive assay of extrinsic coagulation pathway inhibitor (EPI) in plasma and plasma fractions. Thromb Res 1987;47:389400.

15. Hancock WW, Grey ST, Hau L, Akalin E, Orthner C, Sayegh MH, Salem HH. Binding of activated protein $\mathrm{C}$ to a specific receptor on human mononuclear phagocytes inhibits intracellular calcium signaling and monocyte-dependent proliferative responses. Transplantation 1995;60(12):1525-32.

16. Grey ST, Tsuchida A, Hau H, Orthner CL, Salem HH, Hancock WW. Selective inhibitory effects of the anticoagulant activated protein $\mathrm{C}$ on the responses of human mononuclear phagocytes to LPS, IFN- $\gamma$, or phorbol ester. J Immunol 1994;153:3664-72.

17. Østerud B. Tissue factor expression by monocytes: regulation and pathophysiological roles. Blood Coag Fibrinol 1998;9(suppl 1):S9-S14. 
18. Kakkar AK, DeRuvo N, Chinswangwatanakul V, Tebbutt S, Williamson RCN. Extrinsic-pathway activation in cancer with high factor VIla and tissue factor. Lancet 1995;346:1004-5.

19. Costantini V, De Monte $P$, Cazzato AO, Stabile AM, Deveglia R, Frezzato E, Paolucci MC. Systemic thrombin generation in cancer patients is correlated with extrinsic pathway activation. Blood Coagul Fibrinolysis 1998;9:79-84.

20. Hancock WW, Tsuchida A, Hau H, Thomson NM, Salem HH. The anticoagulants protein $\mathrm{C}$ and protein $\mathrm{S}$ display potent anti-inflammatory and immunosuppressive effects relevant to transplant biology and therapy. Transplant Proc 1992;24(5):2302-3.

21. Ten Cate JW, van der Poll $T$, Levi $M$, ten Cate $H$, van Deventer SJ. Cytokines: triggers of clinical thrombotic disease. Thromb Haemost 1997;78(1):415-9.

22. Nakashima J, Tachibana M, Ueno M, Baba S, Tazaki H.. Tumor necrosis factor and coagulopathy in patients with prostate cancer. Cancer Res 1995;55:4881-5.

23. Wada H, Tamaki S, Tanigawa M, Takagi M, Mori Y, Deguchi A, Katayama N, Yamamoto T, Deguchi K, Shirakawa S. Plasma level of IL-1 beta in disseminated intravascular coagulation. Thromb Haemost 1991;65(4):364-8.

24. Wada H, Tanigawa M, Wakita Y, Nakase T, Minamikawa K, Kaneko T, Ohiwa M, Kageyama S, Kobayashi T, Noguchi T, Shirakawa S. Increased plasma level of interleukin-6 in disseminated intravascular coagulation. Blood Coag Fibrinol 1993;4(4):583-90

25. Saleh MN, Goldman SJ, LoBuglio AF, Beall AC, Sabio H, McCord MC, Minasian L, Alpaugh RK, Weiner LM, Munn DH. CD16+ monocytes in patients with cancer: spontaneous elevation and pharmacologic induction by recombinant human macrophage colony-stimulating factor. Blood 1995;85(10):2910-7.

26. Ziegler-Heitbrock HW, Fingerle G, Strobel M, Schraut W, Stelter F, Schutt C, Passlick B, Pforte A. The novel subset of CD14+/CD16+ blood monocytes exhibits features of tissue macrophages. Eur J Immunol 1993;23:2053-8.

27. Van Ravenswaay Claasen $\mathrm{HH}$, Kluin PM, Fleuren GJ. Tumor infiltrating cells in human cancer: on the possible role of CD16+ macrophages in antitumor cytotoxicity. Lab Invest 1992;67(2):166-74 


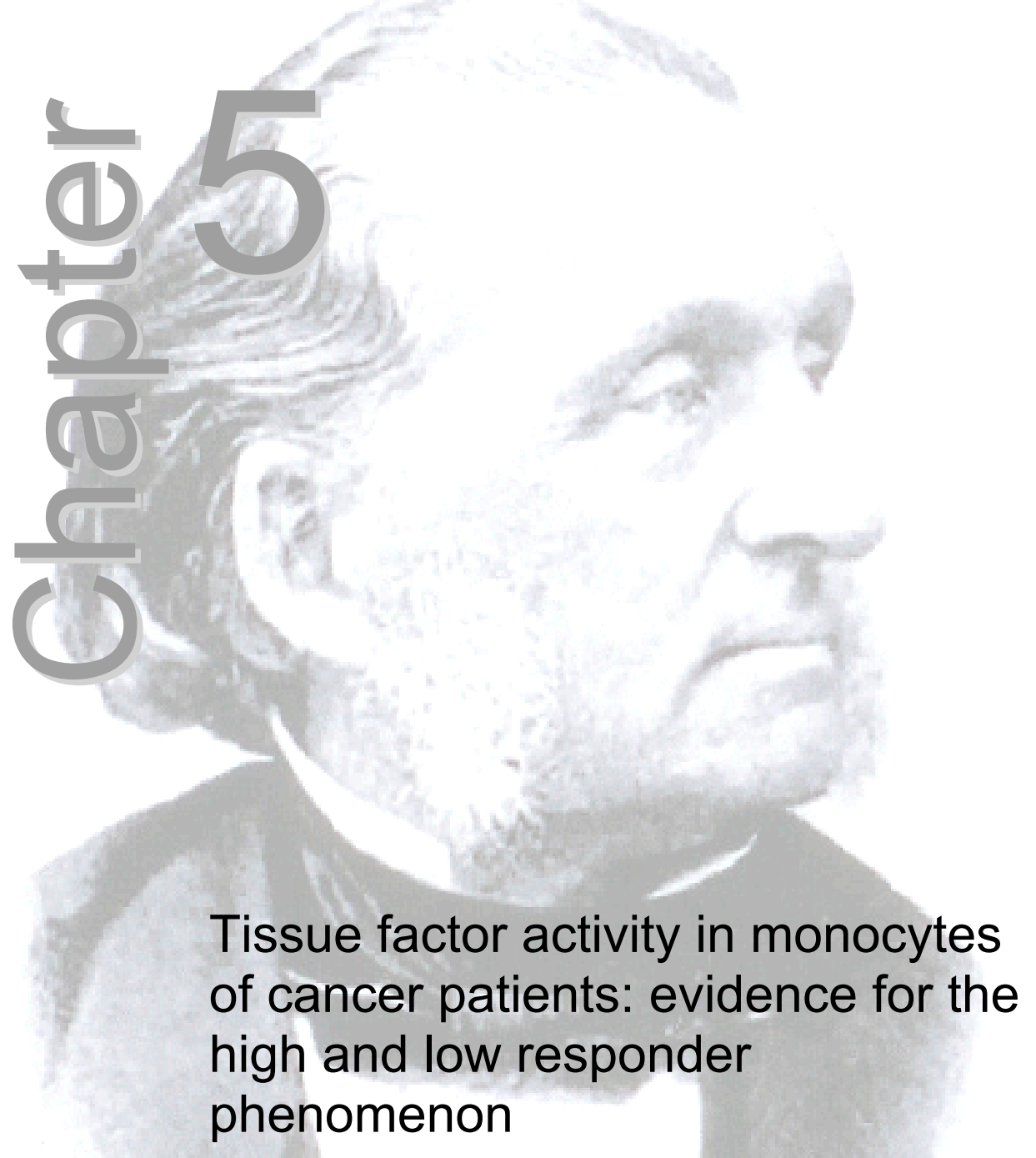

Marten R Nijziel, René van Oerle, Elisabeth $\mathrm{CM}$ van Pampus, Harry FP Hillen, Karly Hamulyák 


\section{Summary}

Tissue factor (TF) is the primary activator of blood coagulation in normals, but especially in patients with cancer. Upon stimulation, monocytes of some individuals express more TF than monocytes of others. In the literature this difference is known as the "high and low responder phenomenon" of monocyte TF activity. This phenomenon could play a role in the cancer related hypercoagulability. Monocyte TF activity was measured in twelve cancer patients with advanced disease compared with twelve age and sex matched healthy controls. By flowcytometry monocyte TF activity was $9.9 \%$ in the cancer patients vs. $10.7 \%(p=0.48)$ in the controls. By plasma stimulation monocyte TF activity was $827 \mathrm{fM}$ in the cancer patients vs. $1388 \mathrm{fM}(p=0.59)$ in the controls. Five cancer patients had a monocyte TF activity above $1500 \mathrm{fM}$ (the high responders); seven cancer patients had a monocyte TF activity of less than $1000 \mathrm{fM}$ (the low responders). In the patient group a significantly elevated D-dimer level $(3,451$ vs. $0.308 \mu \mathrm{g} / \mathrm{ml} ; p<0.001)$, a significantly elevated CRP (119.3 vs. $4.0 \mu \mathrm{g} / \mathrm{m} ; \mathrm{p}=0.001)$ and a significantly increased expression of CD16 on monocytes (31.5 vs. $18.0 \%$; $p=0.02)$ was found in comparison with the normal controls. There was no correlation between the Ddimer level, CRP or CD16 and the TF measured in either of the tests. Although the high and low responder phenomenon could be demonstrated in the cancer patients, the response was not higher compared to the control group. 


\section{Introduction}

There is now considerable evidence that cancer cells activate the haemostatic system. This activation leads to a chronic state of hypercoagulability and to an increased risk of developing thrombosis in patients with cancer. In this process tissue factor (TF) plays a central role as activator of the blood coagulation ${ }^{1}$. One of the possible pathways whereby a cancer cell activates the coagulation system is by inducing monocyte TF activity. The evidence for this proposed mechanism is mainly based on in vitro studies using isolated monocytes and lipopolysaccharide (LPS) stimulation ${ }^{2-5}$. There is evidence that the monocyte TF stimulation in vivo might be different. For instance, it has recently been shown that indeed TF mRNA levels in leukocytes of cancer patients are increased, however without any correlation with plasma levels of TF antigen in these patients ${ }^{6}$. In our previous study TF expression on peripheral monocytes measured by flowcytometry was not increased in a heterogenic cohort of cancer patients with advanced disease, although a direct work-up of unstimulated whole blood was done ${ }^{7}$. In spite of the scarce evidence in vivo, increased monocyte TF activity is still thought by many to contribute to cancer related hypercoagulability.

An important factor to be considered is the individual variation in monocyte TF activity upon stimulation, known as the "high and low responder phenomenon"8${ }^{10}$. It has been shown that in healthy volunteers granulocytes and platelets increase the LPS induced monocyte TF activity and therefore play an important role in this phenomenon ${ }^{9}$. We demonstrated that in the absence of granulocytes, platelets and LPS, plasma determines the high and low responder phenomenon and that this is not influenced by coumarin treatment ${ }^{10}$. It has been suggested that a high response might make individuals more susceptible to hypercoagulation ${ }^{8}$.

We hypothesized that a possible mechanism of monocyte TF activity in cancer patients is that these patients shift from low to high responders, thereby expressing more TF than healthy controls upon stimulation by plasma. Therefore, monocyte TF activity was measured by flowcytometry and by measuring activity in isolated human monocytes after incubation in a plasma environment depleted of granulocytes, platelets and LPS. Healthy volunteers and cancer patients with advanced disease were evaluated.

\section{Materials and methods}

\section{Patients}

Twelve consecutive cancer patients with advanced metastatic disease (six colorectal cancer, six breast cancer; mean age 54.9 years, range 18 to 75 
years; eight female, 4 male) and twelve age and sex matched healthy controls (mean age 54.5 years, range 18 to 75 years, eight female, four male) were studied. All cancer patients were off treatment because of progression of the disease. Their last chemotherapy was at least four weeks before sampling of the blood. All patients and volunteers agreed to participate in the study following informed consent. The study was approved by the Ethical Review Committee of the University Hospital Maastricht.

\section{Blood collection and plasma preparation}

From the antecubital vein $25 \mathrm{ml}$ of blood was collected with a Strauß Kanüle $1,2 \times 43 \mathrm{~mm}$ (Lameris, the Netherlands) without venous stasis. The first $3 \mathrm{ml}$ were discarded. The next $18 \mathrm{ml}$ were collected into two $10 \mathrm{ml}$ plastic tubes $(16,8 \times 100 \mathrm{~mm}, 164180$, Greiner, Germany) containing $1 \mathrm{ml}$ of sodium citrate $3.8 \%$ each. Citrated platelet poor plasma was made using two centrifuge steps (five minutes $4000 \mathrm{rpm}$ and ten minutes $11000 \mathrm{rpm}$ ). The last $4 \mathrm{ml}$ were collected into a plastic tube containing $7.2 \mathrm{mg}$ EDTA $\left(\mathrm{K}_{2}\right)$ (Becton Dickinson Europe, France) and processed directly for flowcytometric analysis. All blood samples were processed within 30 minutes after the collection. The samples of a cancer patient and the matched control were taken and directly worked up and measured together on the same day to prevent any bias.

\section{Monocyte tissue factor measurement}

Monocyte TF was measured by flowcytometry and by plasma stimulation of isolated monocytes, in detail described before ${ }^{7,10}$. For better understanding both methods are summarized below.

Flowcytometric analysis was performed using mouse anti-human monoclonal antibodies (mAbs) against CD14 (PE conjugated; Becton Dickinson), CD16 (FITC conjugated; CLB, Amsterdam, the Netherlands) and tissue factor (FITC conjugated; American Diagnostica). All incubation steps were done in plastic $12 \times 75 \mathrm{~mm}$ tubes (Falcon; purchased from Becton Dickinson). All centrifugation steps were for five minutes at $2000 \mathrm{rpm}$. In all procedures mouse isotype negative controls (CLB, Amsterdam, the Netherlands) were measured. First $2 \mathrm{ml}$ EDTA anticoagulated whole blood was incubated with $40 \mu \mathrm{l} \mathrm{Fc-receptor}$ Blocking Reagent (human IgG, Miltenyi Biotec $\mathrm{GmbH}$, Bergisch Gladbach, Germany) for 10 minutes at $4^{\circ} \mathrm{C}$ in the dark. Then samples of $100 \mu \mathrm{l} \mathrm{FC}$ receptor blocked whole blood were incubated for 30 minutes at $4^{\circ} \mathrm{C}$ in the dark with $10 \mu \mathrm{l}$ of a FITC-conjugated mAb and $5 \mu \mathrm{l}$ of the CD14 PE mAb. Finally red cells were lysed with diluted Becton Dickinson FACS Lysing Solution 349202 according to the standard procedure. After washing twice with $3 \mathrm{ml}$ of PBN, the cells were resuspended in $300 \mu \mathrm{l}$ of PBN and stored for maximally two hours at $4^{\circ} \mathrm{C}$ prior to flow cytometric analysis. Data acquisition and analysis were 
performed on a FACSCalibur flow cytometer using CELLQuest software (both Becton Dickinson). Monocytes were identified using the CD14 PE-conjugated $\mathrm{mAb}$ and the forward and sideward light scatter pattern. $5000 \mathrm{CD} 14$ positive cells were counted. The negative and positive delineator was positioned by determining $5 \%$ background staining on the isotype control fluorescence. Then the percentage of the FITC positive events was measured in the monocyte gate.

Plasma stimulation of isolated monocytes was performed as follows: peripheral blood monocytes were collected from a healthy non-smoking female donor (48 years old, not using any medication) by leukapheresis, followed by sterile multiple chamber counterflow centrifugation. The citrated $(0.13 \mathrm{M})$ leukocyte concentrate, obtained by leukapheresis, was diluted in PBS buffer with $0.2 \%$ human serum albumin (CLB, Amsterdam, the Netherlands) and $0.2 \%$ glucose $(\mathrm{pH} 7.3)$. After density gradient centrifugation on Percoll $1.073 \mathrm{~g} / \mathrm{ml}$ at $4^{\circ} \mathrm{C}$, the mononuclear fraction was purified in a four-chamber sterile CCE rotor constantly controlling the outflow by using a computerized scatter-monitor device. Under a constant flow rate and a constant rotor speed, cells were loaded up to $2 \times 10^{9}$ cells per chamber. PBS buffer with $0.2 \%$ human serum albumin and $0.2 \%$ glucose was used as elutriant. By reducing the rotor speed stepwise cell fractions were washed out and fractions containing more than $93 \%$ monocytes were collected. The cells were pooled and resuspended in a final concentration of $5 \times 10^{6}$ cells $/ \mathrm{ml}$ in a freeze medium consisting of $30 \%$ autologous citrated plasma, 60\% Iscove's (Gibco) and 10\% DMSO. Next the cells were frozen at $-180^{\circ} \mathrm{C}$ in aliquots of $1 \mathrm{ml}$ in sterile cryovials in a cryostat using a standard controlled freezing procedure. After thawing at room temperature the cryopreserved monocytes had a viability of $85 \%$ as shown by trypan blue exclusion. The cells were washed twice at $4^{\circ} \mathrm{C}$ with sterile LPS free Hanks balanced salt solution (HBSS) without calcium and magnesium. In a 96 wells round bottom microtitre plate $1.0 \times 10^{5}$ monocytes per well were cultured for three hours at $37^{\circ} \mathrm{C}$ with addition of $10 \mu \mathrm{l}$ calcium and magnesium (final concentration per well: $5 \mathrm{mM}$ and $2 \mathrm{mM}$ respectively), $10 \mu$ unfractionated heparin $(2.5 \mathrm{U} / \mathrm{ml})$ and $10 \mu \mathrm{l}$ polymyxin $\mathrm{B}(10 \mu \mathrm{g} / \mathrm{ml})$ to prevent a stimulatory effect on the monocyte TF activity by trace amounts of LPS in any of the reagents or monocyte cultures. Next $40 \mu$ citrated platelet poor plasma of a cancer patient or matched healthy control was added, which was $20 \%$ of the total volume of $200 \mu \mathrm{l}$ per well. The total volume per well was completed to 200 $\mu \mathrm{l}$ with HBSS. After the three hour incubation period the monocytes were washed with Tris/EDTA buffer and then twice with HBSS. Between the washing steps the cells were centrifuged in the microtitre plate for three minutes at $150 \mathrm{~g}$. Finally $50 \mu \mathrm{l} \mathrm{HBSS}$ per well was added. After three freeze-thaw steps to lyse the cells the microtitre plate was stored at $-70^{\circ} \mathrm{C}$ until tissue factor 
measurement. Monocyte tissue factor activity was measured using a two-stage tissue factor assay measuring thrombin at $37^{\circ} \mathrm{C}$. After thawing the lysed cells, $1.25 \mu \mathrm{M}$ prothrombin, $160 \mathrm{pM}$ bovine factor $\mathrm{V}$ and $20 \mu \mathrm{M}$ phospholipid vesicles DOPS/DOPC 20/80 in $25 \mu \mathrm{l}$ HEPES/BSA buffer with $5 \mathrm{mM}$ calcium was added. Next $25 \mu \mathrm{l}$ of a HEPES/BSA buffer containing $0.5 \mathrm{nM}$ human recombinant factor VIla, $10 \mathrm{nM}$ bovine factor $X$ and $5 \mathrm{mM}$ calcium was added. After exactly three minutes of incubation under constantly shaking, $25 \mu \mathrm{l}$ of the mix was transferred into $175 \mu \mathrm{l}$ Tris/EDTA buffer to stop thrombin formation. Thrombin was measured by adding $50 \mu \mathrm{l}$ chromogenic substrate S2238 (final concentration $0.2 \mathrm{mM}$ ). Substrate conversion was measured kinetically on a Biorad microtitre plate reader at $37^{\circ} \mathrm{C}$. Under the conditions of the assay the rate of substrate conversion is proportional to the tissue factor concentration in the lysed cells. Concentrations are expressed in fM tissue factor (final concentration) by comparison to a standard curve of known tissue factor concentrations. Calculated concentrations were means of at least triple simultaneous measurements in the same microtitre plate.

\section{Determination of other laboratory parameters}

D-dimers and C-reactive protein (CRP) were determined according to standard operating procedures in the laboratory of hematology and the laboratory of clinical chemistry of the University Hospital of Maastricht.

\section{Statistics}

The data were analyzed using SPSS for Windows (SPSS Inc., Chicago, USA). Non-parametric tests for independent samples were used. To compare the variables in the patient groups and the controls a Mann-Whitney U-test was performed. The differences were considered significant at $p<0.05$. Results are given as medians. Spearman correlation coefficients were calculated to examine the correlation between the various parameters. Interim analysis was planned after inclusion of twelve patients and controls.

\section{Results}

In the cancer patient group the high and low responder phenomenon could be demonstrated clearly with the plasma stimulation test. Figure 5.1 shows that five cancer patients had a monocyte TF activity response above $1500 \mathrm{fM}$ (high responders), whereas the seven other patients had a monocyte TF activity of less than $1000 \mathrm{fM}$ (low responders). However, there was no significant difference in monocyte TF activity between cancer patients with advanced disease and age and sex matched healthy controls in either of the tests. 
By flowcytometry the monocyte TF activity was $9.9 \%$ in the cancer patients vs. $10.7 \%(p=0.48)$ in the healthy controls. By plasma stimulation the monocyte TF activity was $827 \mathrm{fM}$ in the cancer patients vs. $1388 \mathrm{fM}(p=0.59)$ in the healthy controls. There was a remarkable correlation between the monocyte TF activity measured by flowcytometry and the monocyte TF activity measured by plasma stimulation $(r=0.67 ; p<0.001)$, emphasizing the accuracy of the measurements (Figure 5.1).

In the cancer patients we could demonstrate a significantly elevated D-dimer level (3,451 vs. $0.308 \mu \mathrm{g} / \mathrm{ml} ; \mathrm{p}<0.001)$, a significantly elevated CRP (119.3 vs. $4.0 \mu \mathrm{g} / \mathrm{m} ; \mathrm{p}=0.001)$ and a significantly increased expression of CD16 on monocytes (31.5 vs. $18.0 \% ; p=0.02)$. There was no correlation between the $D-$ dimer level, CRP or CD16 and the TF measured in either of the tests.

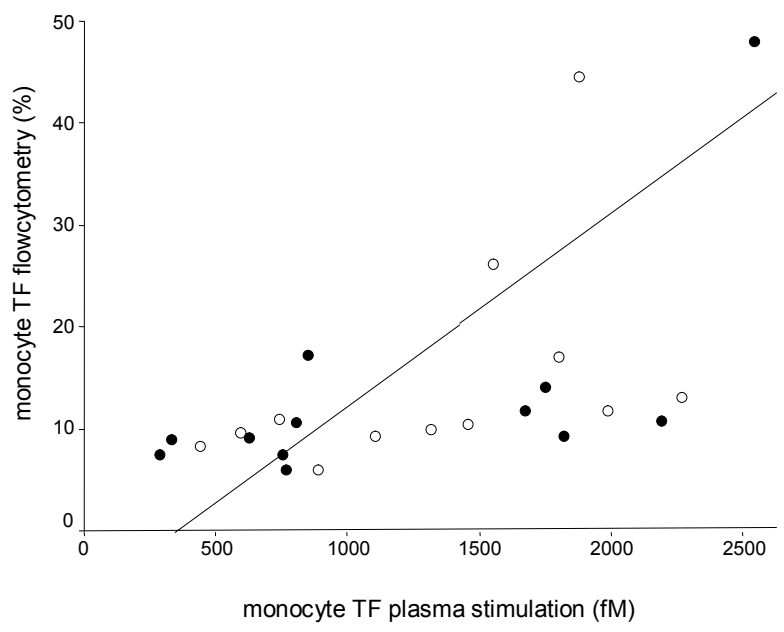

Figure 5.1 Monocyte tissue factor activity measured by plasma stimulation of isolated monocytes (monocyte TF plasma stimulation) correlated with monocyte tissue factor activity measured by flowcytometry (monocyte TF flowcytometry) in patients with advanced disseminated breast or colorectal cancer (closed dots) and age and sex matched healthy controls (open dots): $r=0.67 ; p<0.001$.

\section{Discussion}

This study shows that in this group of patients with breast and colorectal cancer with advanced disease there was no evidence of in vivo elevated monocyte TF activity. There was neither difference by measuring monocyte TF activity with 
flowcytometry nor by measuring TF activity on healthy monocytes stimulated by plasma of cancer patients. In the latter measurements there was no sign of cancer patients being high responders compared to healthy controls. The study was interrupted after measuring twelve patients and twelve age- and sexmatched healthy controls. At that point in the evaluation there was no significant difference in monocyte TF activity between the patients with advanced disease and the healthy volunteers. In fact, there was a trend towards higher monocyte TF activity in the controls.

It has been shown that upon stimulation monocytes of some individuals have a higher TF activity than monocytes of others, the so-called "high and low responder phenomenon"8-10. In a previous study we have demonstrated that in the absence of granulocytes, platelets and LPS, plasma determines the monocyte TF activity ${ }^{10}$. This plasma-induced high and low responder phenomenon in healthy subjects is again demonstrated in the current study. Moreover, this is the first study that demonstrates the high and low responder phenomenon in cancer patients (Figure 5.1). Remarkably, all cancer patients had a plasma stimulated monocyte TF activity of less than $1000 \mathrm{fM}$ (the low responders) or higher than $1500 \mathrm{fM}$ (the high responders). However, contrary to our hypothesis, in this group of cancer patients it has not been demonstrated that cancer patients shift from low to high responders and thereby have a higher monocyte TF activity than healthy controls.

It has been suggested that individuals with a higher response are more susceptible to hypercoagulation ${ }^{8}$. Although in the cancer patients in this study no arterial or venous thromboembolism has been seen, the highly elevated D-dimer level in this patient group suggests activation of the coagulation and fibrinolytic system. This is completely in line with previous reports ${ }^{7,11-13}$. However, no correlation was found between the monocyte TF activity and the D-dimer in either of the tests, emphasizing that high responders do not have the highest D-dimer levels. Contrary to what is generally thought this makes a role of in vivo monocyte TF activity less clear. To our experience the patients involved in this study form a representative cohort of daily practice cancer patients with advanced disease. Therefore we argue that the results of this study again make it doubtful whether tissue factor expression on the surface of monocytes is really playing an important role in the hypercoagulability in cancer.

What could be the explanation for the fact that we do not measure increased monocyte TF activity in the cancer patients compared with healthy controls? First, because only $10 \%$ to $20 \%$ of the total extractable TF activity is expressed on the membrane of intact monocytes, 80 to $90 \%$ of the TF remains in the monocyte and can not be measured by flowcytometry ${ }^{8}$. However, in the plasma measurements after three hours of incubation the TF was measured after three freeze-thaw steps to lyse the monocytes. Thus, all TF expressed on the 
membrane of the monocyte and all TF encrypted in the monocyte should have been measured. Secondly, it has been hypothesized that monocyte derived TF in cancer patients is present in the microparticle fraction that is not quantified with either of the tests ${ }^{14}$. These particles are too small to be seen by flowcytometry using light scattering and can only be seen by flowcytometry using impedance to measure particle size ${ }^{15}$. By lysing the monocytes and the washing steps that were used, microparticles were probably washed out. Therefore, TF in the microparticle fraction was probably not measured in the plasma tests. Third, the activation of the haemostatic system in cancer patients, including the patients in this study, can be due to many other, probably more important, activating mechanisms, as TF expression on tumor cells themselves, not measured with either of our tests ${ }^{16}$.

In conclusion, in this small but representative group of cancer patients we failed to show elevated monocyte TF activity compared with age- and sex-matched healthy controls. The "high and low responder phenomenon" could be demonstrated in the healthy volunteers as well as in the cancer patients with advanced disseminated disease. There was no proof that cancer patients with an activation of the coagulation, as demonstrated by elevated D-dimer levels, were higher responders of monocyte TF activity than healthy controls. This study suggests that the haemostatic system in cancer patients is activated by other mechanisms than monocyte TF activity. 


\section{References}

1. Belting M, Ahamed J, Ruf W. Signaling of the tissue factor coagulation pathway in angiogenesis and cancer. Arterioscler Thromb Vasc Biol 2005;25:1545-50

2. Edwards RL, Rickles FR, Cronlund M. Abnormalities of blood coagulation in patients with cancer. Mononuclear cell tissue factor generation. J Lab Clin Med 1981;98:917-28.

3. Morgan D, Edwards RL, Rickles FR. Monocyte procoagulant activity as a peripheral marker of clotting activation in cancer patients. Haemostasis 1988;18:55-65.

4. Semeraro N, Montemurro P, Conese M, Giordano D, Stella M, Restaino A, Cagnazzo G, Colucci M. Procoagulant activity of mononuclear phagocytes from different anatomical sites in patients with gynaecological malignancies. Int $\mathrm{J}$ Cancer 1990;45:251-4.

5. Lwaleed BA, Chisholm M, Francis JL. The significance of measuring monocyte tissue factor activity in patients with breast and colorectal cancer. $\mathrm{Br} \mathrm{J}$ Cancer 1999;80:279-85.

6. Sase T, Wada H, Kamikura Y, Kaneko T, Abe Y, Nishioka J, Nobori T, Shiku H. Tissue factor messenger RNA levels in leucocytes compared with tissue factor antigens in plasma from patients in hypercoagulable states caused by various diseases. Thromb Haemost 2004;92:132-9.

7. Nijziel MR, van Oerle R, van Pampus ECM, de Vet HCW, Hillen HFP, Hamulyák $\mathrm{K}$. Increased D-dimer levels correlate with binding of activated protein C, not tissue factor expression, on peripheral blood monocytes in cancer patients. Am J Hematol 2000;64:282-6.

8. Egorina EM, Sovershaev MA, Bjorkoy G, Gruber FX, Olsen JO, Parhami-Seren B, Mann KG, Osterud B. Intracellular and surface distribution of monocyte tissue factor: application to intersubject variability. Arterioscler Thromb Vasc Biol 2005;25:1493-8.

9. Østerud B. The high responder phenomenon: enhancement of LPS induced tissue factor activity in monocytes by platelets and granulocytes. Platelets 1995;6:119-25.

10. Nijziel MR, van Oerle R, van 't Veer C, van Pampus E, Lindhout T, Hamulyák K. Tissue factor activity in human monocytes is regulated by plasma: implications for the high and low responder phenomenon. Br J Haematol 2001;112:98-104.

11. Blackwell K, Haroon Z, Broadwater G, Berry D, Harris L, Iglehart JD, Dewhirst M, Greenberg C. Plasma D-dimer levels in operable breast cancer patients correlate with clinical stage and axillary lymph node status. J Clin Oncol 2000;18: 600-8.

12. Dirix LY, Salgado R, Weytjens R, Colpaert C, Benoy I, Huget $P$, van Dam $P$, Prove A, Lemmens J, Vermeulen P. Plasma fibrin D-dimer levels correlate with tumour volume, progression rate and survival in patients with metastatic breast cancer. $\mathrm{Br}$ J Cancer 2002;86:389-95.

13. Beer JH, Haeberli A, Vogt A, Woodtli K, Henkel E, Furrer Th, Fey MF. Coagulation markers predict survival in cancer patients. Thromb Haemost 2002;88:745-9.

14. Chou J, Mackman N, Merrill-Skoloff G, Pedersen B, Furie BC, Furie B. Haematopoietic cell-derived microparticle tissue factor contributes to fibrin formation during thrombus propagation. Blood 2004;104:3190-7.

15. Furie B, Zwicker J, LaRocca T, Kos C, Bauer B, Furie BC. Tissue factor-bearing microparticles and cancer-associated thrombosis. Haematologica reports 2005;1(9):5-8. 
16. Ueno $\mathrm{T}$, Toi $\mathrm{M}$, Koike $\mathrm{M}$, Nakamura $\mathrm{S}$, Tominaga $\mathrm{T}$. Tissue factor expression in breast cancer tissues: its correlation with prognosis and plasma concentration. $\mathrm{Br}$ J Cancer 2000;83:164-70. 


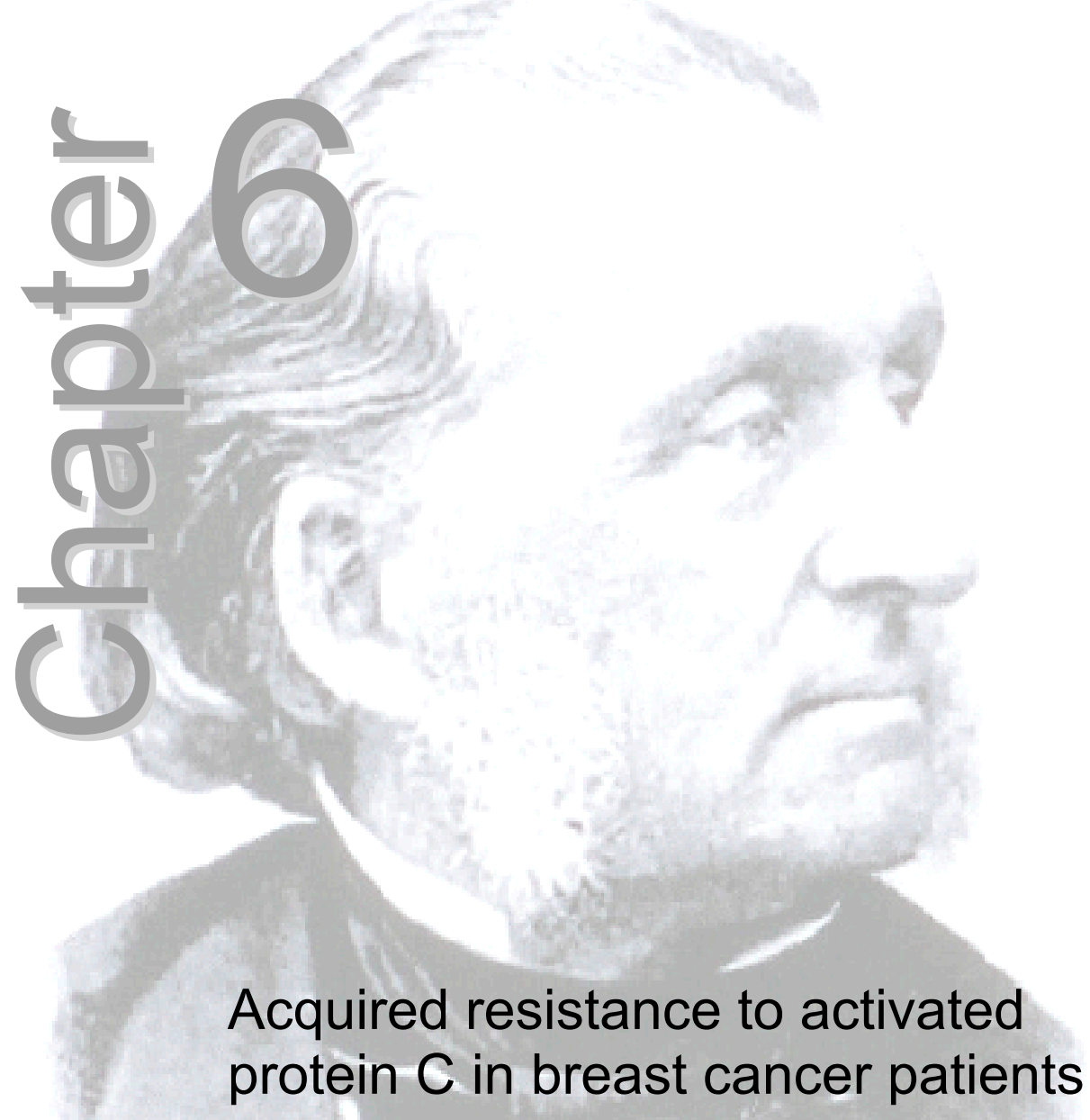

Marten R Nijziel, René van Oerle, M Christella LGD Thomassen, Elisabeth CM van Pampus, Karly Hamulyák, Guido Tans, Jan Rosing Br J Haematol 2003; 120:117-22 


\section{Summary}

In 56 women with a lymph node positive breast carcinoma and 28 matched healthy controls the sensitivity to activated protein C (APC-sr) was determined with an APC resistance test that quantifies the effect of APC on thrombin generation initiated via the extrinsic coagulation pathway. Carriers of the Factor $\checkmark$ Leiden mutation were excluded from the study.

Significant resistance to APC was found in the breast cancer patients: median APC-sr 2.02 vs. 1.03 in the healthy controls $(p<0.001)$. No difference in APC-sr was found between patients with metastases and without metastases. In patients with metastases protein $S$ levels were significantly elevated compared to patients without metastases and healthy controls: $108.0 \%$ vs. $96.0 \%$ and $94.5 \%(p=0.008$ and $p=0.007)$. The APC-sr correlated with protein $S$ in the controls and in patients without metastases but not in patients with metastases. The disturbance of the hemostatic balance probed by the tissue factor-based APC resistance test might contribute to the cancer-related hypercoagulability. 


\section{Introduction}

Activation of the coagulation system in cancer patients is a long known but still poorly understood phenomenon ${ }^{1-3}$. It is becoming clear that activation of the hemostatic system is involved in tumor cell growth and angiogenesis ${ }^{4-6}$ and symptomatic and recurrent episodes of particularly venous thromboembolism in cancer patients are common ${ }^{7,8}$. However, in many cancer patients the coagulation system is activated without clinical signs of thromboembolism.

The hypercoagulability that occurs with cancer has been described to associate with increased levels of coagulation factors e.g. tissue factor and factor VIla ${ }^{9}$. The possibility of increased thrombin formation as a result of decreased levels of anticoagulant factors e.g. antithrombin or the proteins of the protein $\mathrm{C}$ pathway has gained much less attention.

Hereditary resistance to activated protein $C$ (APC), due to a mutation in coagulation factor $\mathrm{V}$ at an APC cleavage site, is associated with hypercoagulability and an increased risk of venous thromboembolism ${ }^{10-12}$. Recently, it was reported that APC resistance in the absence of factor $V$ Leiden (e.g. acquired APC resistance) is an independent risk factor for venous thrombosis ${ }^{13,14}$. Moreover, acquired APC resistance has been proposed to explain the increased risk of venous thromboembolism associated with the use of oral contraceptives ${ }^{15-17}$. Although hereditary APC resistance as such is not more common in cancer patients than in the normal population, there are indications that cancer patients without the factor $\mathrm{V}$ Leiden mutation may develop acquired APC resistance ${ }^{18,19}$. A state of acquired APC resistance might play a role in the hypercoagulability related to cancer and its therapy.

It appears that acquired APC resistance is especially observed with an APC resistance test that probes the effect of APC on the extrinsic coagulation ${ }^{16}$. Since in cancer patients the extrinsic coagulation pathway is activated ${ }^{9,20}$, in this study acquired resistance to APC was examined in breast cancer patients by quantifying the effect of APC on thrombin generation initiated via the extrinsic coagulation pathway.

\section{Materials and methods}

\section{Patients}

Fifty six women with a breast carcinoma (mean age $57.2 \pm 8.7$ years; median age 55 , range 46 to 79 years) and 28 healthy female controls not using any medication (mean age $57.8 \pm 9.0$ years; median age 56 , range 46 to 79 years) were studied. All breast cancer patients were collected from the out-patient clinic during follow-up after a TxN1M0 tumor treated with resection, axillary lymph node dissection and adjuvant systemic chemotherapy. In all patients last 
chemotherapy was at least one year before start of the study. At the time of drawing the blood samples in the breast cancer group 28 patients had proven metastases (mean age $58.6 \pm 10.2$ years; median age 56.5 , range 46 to 79 years) and 28 patients had no evidence of disease (mean age $55.7 \pm 6.9$ years; median age 54.5, range 46 to 77 years). The metastases were located in bone (sixteen patients), liver (eight patients), lung (six patients), lymph nodes (five patients), pleura (three patients) and skin (two patients). Ten patients had metastases on multiple locations. The controls were healthy volunteers aged above 45 years. All groups were matched for age. The patient groups were also matched for hormonal tumor treatment. None of the patients or controls had thromboembolic complications. Carriers of factor $V$ Leiden, determined by DNA analysis, were excluded. All patients and volunteers agreed to participate in the study following informed consent. The study was approved by the Ethical Review Committee of the University Hospital Maastricht.

\section{Blood collection and plasma preparation}

Blood was collected from the antecubital vein without venous stasis using a Vacutainer PrecisionGlide ${ }^{\mathrm{TM}}$ needle $0.8 \times 38 \mathrm{~mm}$ into four $3.15 \mathrm{ml} \mathrm{Vacutainer}^{\circledR}$ tubes containing $0.129 \mathrm{M}$ sodium citrate (both Becton Dickinson Europe, France). The first $5 \mathrm{ml}$ were discarded. Citrated platelet poor plasma was made using two centrifuge steps: 5 minutes $4000 \mathrm{rpm}(2150 \mathrm{~g})$ at room temperature and ten minutes $11000 \mathrm{rpm}(11000 \mathrm{~g})$ at $4^{\circ} \mathrm{C}$. The blood samples were processed within 30 minutes after the collection. The plasma samples were stored at $-70^{\circ} \mathrm{C}$ in aliquots of $500 \mu$ until analysis.

\section{Determination of the coagulation parameters}

APC sensitivity ratios (APC-sr) were determined with an APC resistance test the principle of which has been described extensively before ${ }^{15,16}$. In short, this assay is based on quantification of the effect of 5 nM APC on thrombin generation initiated in defibrinated platelet poor plasma with $15 \mu \mathrm{M}$ phospholipid vesicles (PS/PE/PC 20/20/60), $0.4 \mathrm{ng} / \mathrm{ml}$ relipidated recombinant tissue factor and $15 \mathrm{mM} \mathrm{CaCl}_{2}$ (final concentrations in plasma). The APC-sr determined by this method shows trends opposite to those determined with the classical APTT-based APC resistance assay. With the method used here a higher APC-sr means a higher resistance to the anticoagulant action of APC (i.e. a lower sensitivity to APC).

Antithrombin, $\alpha 2-$ macroglobulin, factor VII, prothrombin and total protein $\mathrm{S}$ antigen were measured according to standard laboratory procedures. All commercially available assays were carried out according to the manufacturer's instructions. Antithrombin was measured using the Coamatic ${ }^{\circledR}$ antithrombin kit (Chromogenix, Sweden). $\alpha 2$-macroglobulin was determined via its ability to inhibit trypsin added to diluted plasma samples using the Coaset $^{\circledR}$ 
a2-macroglobulin kit (Chromogenix). Factor VII was measured using a onestage factor coagulation assay with factor VII-deficient plasma (Organon, the Netherlands) and Thromborel $S^{\circledR}$ (OUHP 13, Dade/Behring, Germany). Prothrombin was determined using a one-stage clotting assay with prothrombin-deficient plasma (Dade/Behring) and Thromborel $S^{\circledR}$. Total protein $S$ was measured by ELISA using capture antibody A384 and conjugate P419 (both Dakopatts a/s, Denmark). For all measurements the $100 \%$ level was defined as the level determined in the normal plasma pool.

Because in a pilot study no correlation was found between the APC-sr and factor VIII levels, in this study factor VIII was not measured ${ }^{21}$.

\section{Statistics}

The data were analyzed using SPSS for Windows version 8.0 (SPSS Inc., Chicago, USA). Non-parametric tests for independent samples were used. To compare the variables in the patient groups and the controls a Mann-Whitney U-test was performed. The differences were considered significant at $p<0.05$. Results are given as medians. Spearman correlation coefficients were calculated to examine the correlation between the various parameters.

\section{Results}

In the total group of breast cancer patients the median APC-sr was significantly higher $(p<0.001)$ compared to the healthy controls: 2.02 vs. 1.03 . Table 6.1 summarizes the coagulation parameters determined in the breast cancer patients and in the healthy controls.

Table 6.1 Coagulation parameters in breast cancer patients and in matched healthy controls.

\begin{tabular}{|c|c|c|c|c|}
\hline & $\begin{array}{l}\text { Healthy } \\
\text { controls } \\
(n=28)\end{array}$ & $\begin{array}{l}\text { Total breast } \\
\text { cancer group } \\
(n=56)\end{array}$ & $\begin{array}{l}\text { Patients without } \\
\text { metastases } \\
(n=28)\end{array}$ & $\begin{array}{c}\text { Patients with } \\
\text { metastases } \\
(n=28)\end{array}$ \\
\hline Age (yrs) & 56.0 & 55.0 & 54.5 & 56.5 \\
\hline APC-sr & 1.03 & $2.02^{b}$ & $2.08^{b}$ & $1.83^{b}$ \\
\hline$\alpha 2 \mathrm{M}(\%)$ & 114.0 & 114.0 & 114.0 & 115.5 \\
\hline Ila formation ${ }_{-A P C}{ }^{a}(\%)$ & 100.0 & $126.0^{b}$ & $125.0^{b}$ & $130.0^{b}$ \\
\hline Antithrombin (\%) & 103.0 & $95.0^{b}$ & $95.0^{b}$ & $95.0^{b}$ \\
\hline Prothrombin (\%) & 100.5 & 102.0 & 100.5 & 106.5 \\
\hline Factor VII (\%) & 116.0 & 113.5 & 120.0 & $101.0^{\mathrm{b}, \mathrm{c}}$ \\
\hline Total protein S (\%) & 94.5 & 102.0 & 96.0 & $108.0^{\mathrm{b}, \mathrm{c}}$ \\
\hline
\end{tabular}

${ }^{\text {a }}$ Ila formation - APC $=$ thrombin formation determined in the absence of APC calculated from the final level of $\alpha 2 \mathrm{M}$-thrombin complex and expressed as percentage of thrombin formation determined in normal pooled plasma; ${ }^{b}$ significant differences between patients and healthy controls; ${ }^{\mathrm{c}}$ significant differences in patients with metastases compared to patients without metastases. 
Total protein S levels were slightly, though not significantly, elevated: $102 \%$ vs. $94.5 \%$. Compared to healthy controls thrombin formation determined in the absence of APC (Ila formation ${ }_{\text {-APC}}$ ) was significantly higher in the cancer patients, $126 \%$ vs. $100 \%(p=0.003)$. Antithrombin levels were significantly decreased: $95.0 \%$ vs. $103 \% \quad(p=0.009)$. No differences were found in $\alpha 2$-macroglobulin $(\alpha 2 \mathrm{M})$, prothrombin and factor VII.

Patients with during follow-up proven metastases and patients without metastases both had a significantly higher APC-sr compared to the healthy controls: 1.83 and 2.08 vs. 1.03 ( $p=0.005$ and $p<0.001$, respectively) (Figure 6.1).

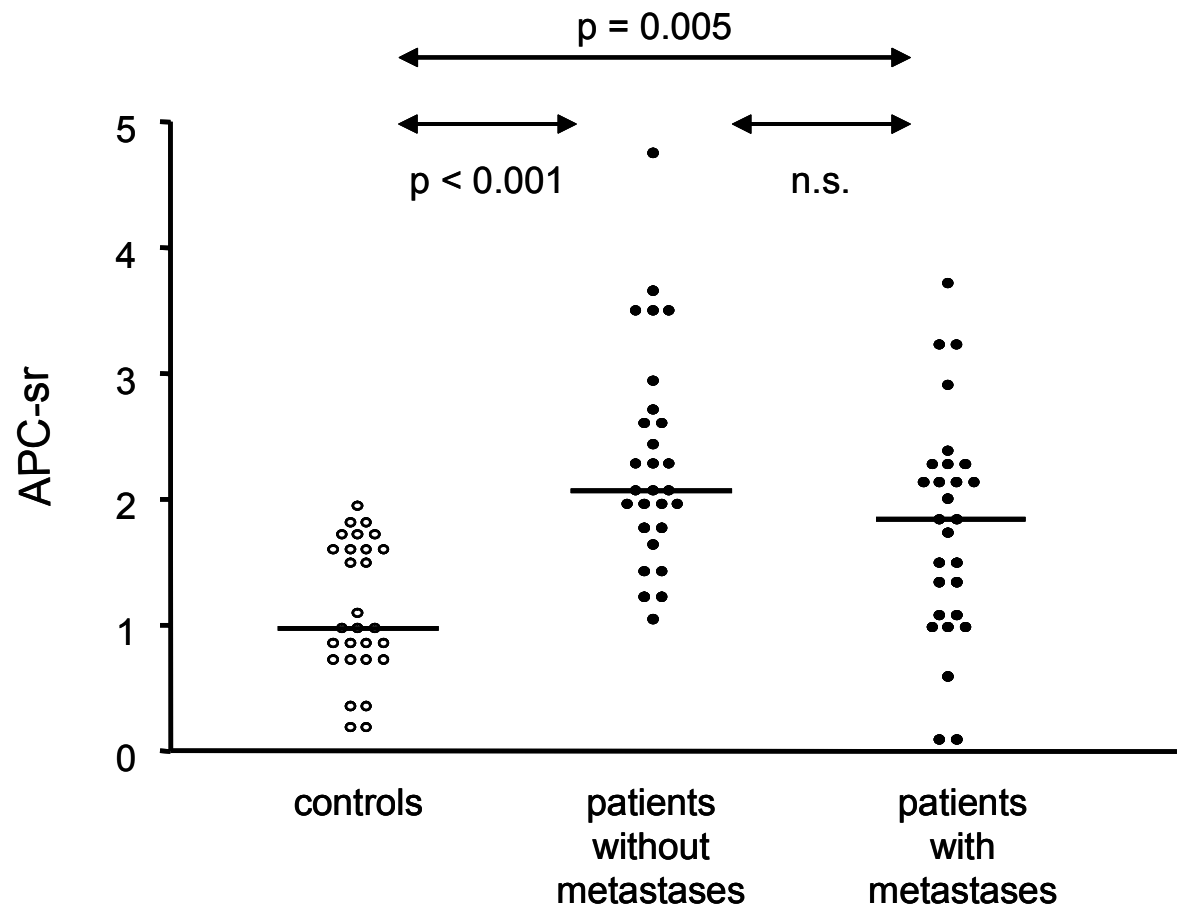

Figure 6.1 APC-sr in breast cancer patients with and without proven metastases compared to agematched healthy controls. The solid lines represent the median APC-sr. 
The difference in APC-sr between patients with and without metastases was not statistically significant. In the patient group with metastases total protein $S$ levels were significantly increased compared to patients without metastases and to healthy controls: $108 \%$ vs. $96.0 \%$ and $94.5 \%$, respectively $(p=0.008$ and $\mathrm{p}=0.007$ ) (Figure 6.2). In addition, factor VII levels in patients with metastases $(101 \%)$ were significantly lower than in patients without metastases $(120 \%$; $p=0.006)$ and in healthy controls $(116 \% ; p=0.025)$. No differences between patients with and without metastases were found in $\alpha 2 \mathrm{M}$, antithrombin and prothrombin (Table 6.1).

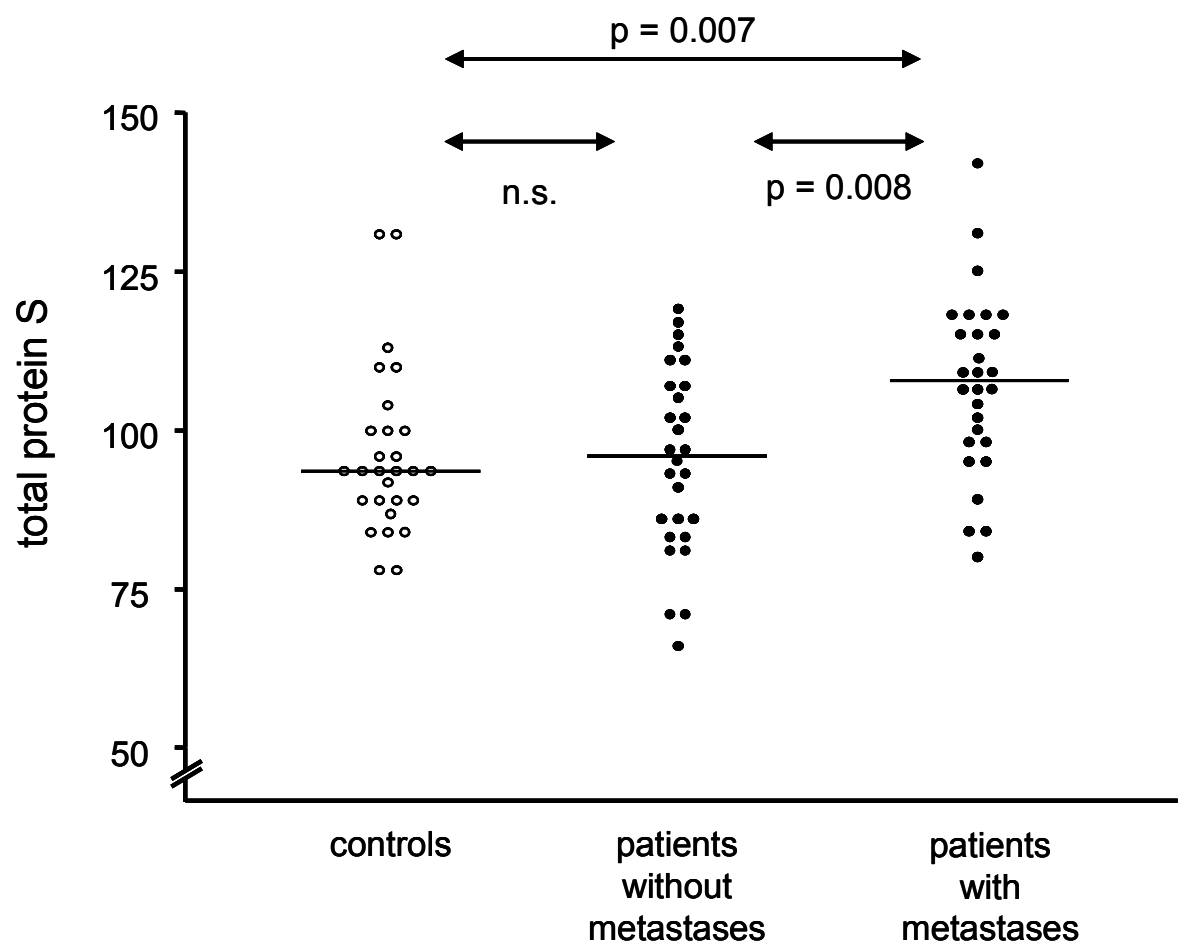

Figure 6.2 Total protein $S$ levels in breast cancer patients with metastases compared to patients without metastases and age-matched healthy controls. The solid lines represent the median APC-sr.

The APC-sr inversely correlated with total protein $S$ levels $(r=-0.68, p<0.001)$ in the control group and in the patient group without metastases $(r=-0.39$, $p=0.04)$. Interestingly, in the patients with metastases no correlation was found between APC-sr and protein S (Figure 6.3) or any of the other coagulation variables. 

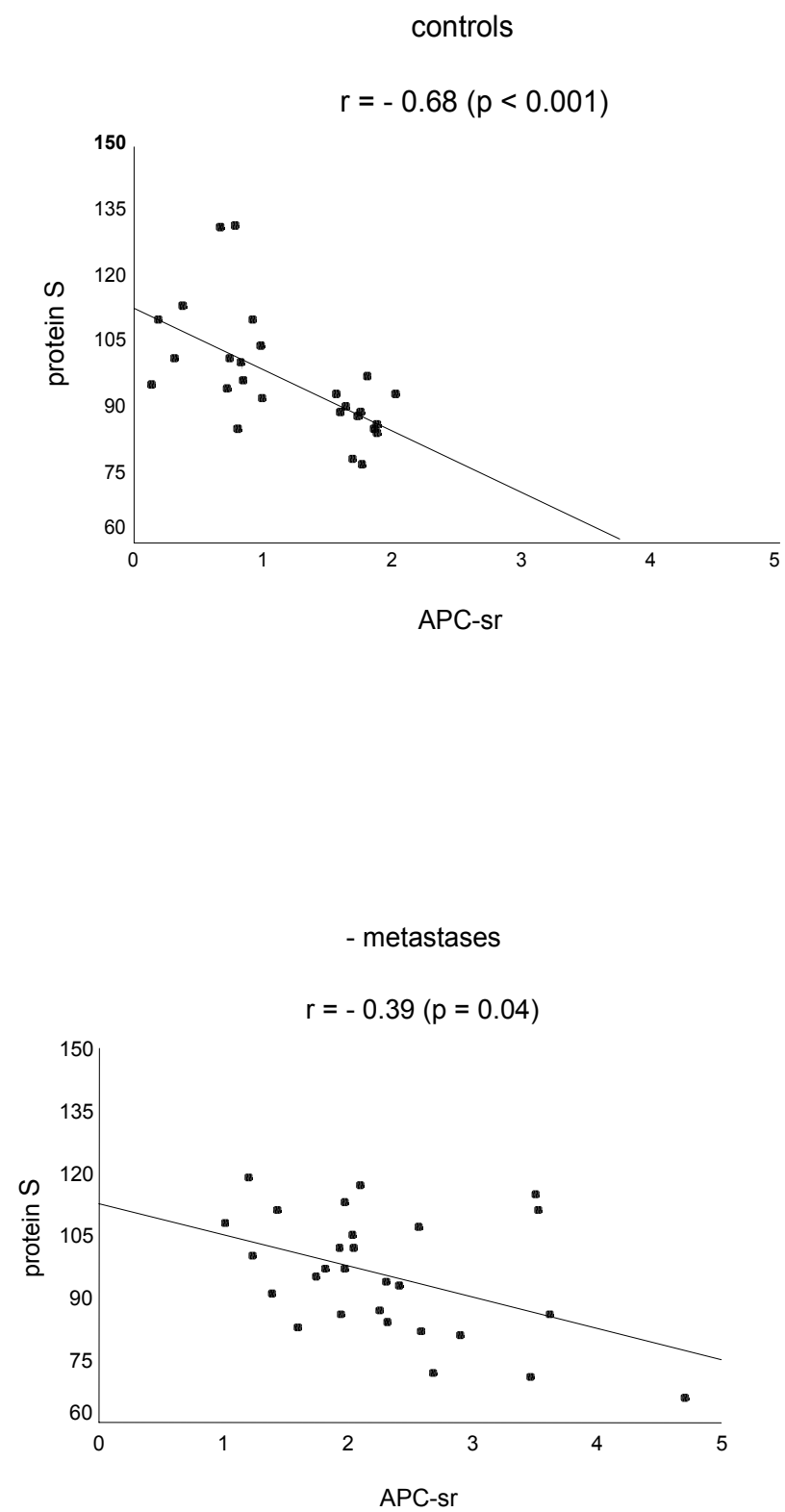


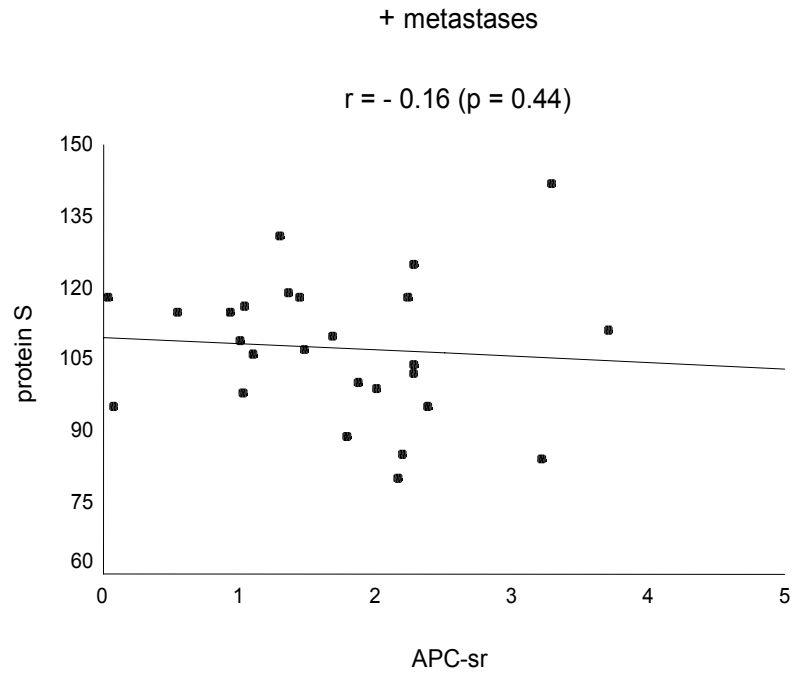

Figure 6.3 Spearman correlations between total protein S levels and the APC-sr in breast cancer patients with proven metastases, in patients without metastases and in age-matched healthy controls.

There were no significant differences in APC-sr and total protein S levels between patients using hormonal tumor treatment $(n=42)$ and those who did not $(n=14): 2.06$ vs. $1.95(p=0.71)$ and $101 \%$ vs. $104.5 \%(p=0.58)$. Table 6.2 summarises all coagulation parameters in the patients using hormonal tumor treatment and the patients not using hormonal tumor treatment.

Table 6.2 Coagulation parameters in the patients using hormonal tumor treatment and the patients not using hormonal tumor treatment.

\begin{tabular}{lccc}
\hline & $\begin{array}{c}\text { Patients with hormonal } \\
\text { tumor treatment } \\
(\mathrm{n}=42)\end{array}$ & $\begin{array}{c}\text { Patients without hormonal } \\
\text { tumor treatment } \\
(\mathrm{n}=14)\end{array}$ & P-value \\
\hline Age (yrs) & 56.0 & 53.5 & 0.57 \\
APC-sr & 2.06 & 1.95 & 0.71 \\
$\alpha 2 \mathrm{M} \mathrm{( \% )}$ & 117.0 & 111.0 & 0.71 \\
Ila formation-APC (\%) & 125.0 & 131.5 & 0.34 \\
Antithrombin (\%) & 94.5 & 98.5 & 0.51 \\
Prothrombin (\%) & 101.0 & 106.0 & 0.57 \\
Factor VII (\%) & 117.5 & 107.0 & 0.39 \\
Total protein S (\%) & 101.0 & 104.5 & 0.58 \\
\hline
\end{tabular}


Patients with metastatic disease in the liver $(n=8)$ compared to patients with metastases at other sites $(n=20)$ did not show significant differences in APC-sr (1.88 vs. $1.83 ; p=0.71)$, total protein $S(107 \%$ vs. $110 \% ; p=0.87)$ and factor VII $(92.0 \%$ vs. $105 \% ; p=0.24)$.

\section{Discussion}

APC and its cofactor protein S play an important role in the in vivo downregulation of thrombin formation. Resistance to APC and congenital deficiencies of protein $\mathrm{C}$ and protein $\mathrm{S}$ are associated with an increased incidence of venous thromboembolism ${ }^{12,22,23}$. This study is the first to demonstrate decreased sensitivity to APC in lymph node positive breast cancer patients compared to matched healthy controls. Because carriers of factor $\mathrm{V}$ Leiden were excluded it is concluded that breast cancer patients have a resistance to APC that is either acquired or due to as yet unidentified hereditary causes.

In contrast to the conventional APTT-based APC resistance test the tissue factor-based APC assay used in this study has been shown to be very sensitive for states of acquired APC resistance such as occurring during oral contraceptive use or pregnancy ${ }^{15-17}$. This assay even discriminated between women using second or third generation oral contraceptives, an observation that may explain differences in thrombotic risks of users of these kinds of oral contraceptives $^{24}$. Since the tissue factor-based APC resistance test probes the effect of APC on thrombin generation initiated via the extrinsic pathway and the APTT-based assay determines the effect of APC on clotting initiated via the intrinsic pathway, it was postulated that plasma proteins involved in the extrinsic pathway modulate the response to APC in the tissue factor-based assay ${ }^{16}$. Particularly extrinsic pathway activation has been described in cancer patients $^{9,20}$. The lower factor VII levels in patients with metastases, in patients with liver involvement as well as in patients with other metastases, indeed suggest, although decreased synthesis or increased clearance can not entirely be ruled out, consumption of factor VII by initiation of the extrinsic pathway. Therefore, it is not surprising that the tissue factor-based test is especially suited to measure APC resistance in cancer patients.

The mechanism of acquired resistance to APC is so far unclear $^{15-17}$. In oral contraceptive users a considerable increase of factor $\mathrm{VII}^{25}$ and decrease of protein $S^{26}$ was observed and it was argued ${ }^{26,27}$ that these changes might at least partly explain acquired APC resistance. The fact that in breast cancer patients without metastases the APC-sr is increased while there are virtually no effects on the plasma levels of factor VII and protein S indicates that changes of other plasma proteins are responsible for acquired APC resistance in these 
patients. In a pilot study we have shown that factor VIII levels in plasma were not influencing the APC-sr ${ }^{21}$ and in the present investigation no correlations between the APC-sr and antithrombin, $\alpha 2 \mathrm{M}$ and prothrombin were found. Although our data indicate that acquired APC resistance in patients is not explained by changes in the level of protein S, the APC-sr of healthy controls showed a significant inverse correlation with the plasma protein $S$ levels, an observation which is in line with the function of protein $S$ as cofactor for APC. The inverse correlation between the APC-sr and the plasma protein $S$ concentration was weaker in patients without metastatic disease. In patients with proven metastases, however, there was no correlation between the APCsr and the total protein S levels (Figure 6.3). In these patients the sensitivity to activated protein $\mathrm{C}$ was decreased, even in the presence of elevated levels of cofactor protein $\mathrm{S}$ (Figure 6.2). This indicates an altered sensitivity of the APCsr to protein $S$ (antigen) levels measured in the plasma of patients with proven metastases for which a number of possible explanations can be put forward. This can be due to an alteration of (the function of) protein $S$ in the patients with metastases, to an alteration of (antigen) response in the ELISA or it may be secondary to changes in the levels or activity of extrinsic pathway factors and regulators which might influence the sensitivity of the APC-sr for protein S. Currently we are investigating whether structural changes in the protein $S$ molecule in cancer patients are involved.

The tissue factor-based APC resistance test did not discriminate between breast cancer patients with proven metastases and breast cancer patients without metastatic disease. It should be stressed that, in the absence of control groups of women with other types of tumors who had received chemotherapy, the results presented here may not be exclusive for the presence of breast cancer per se. However, hormonal tumor treatment was excluded as cause of the increased APC-sr in both patient groups. Interestingly, compared to the healthy controls, patients with metastases as well as patients without metastases had signs of activation of the hemostatic system as demonstrated by the significantly increased thrombin formation in the absence of APC (Ila formation $_{\text {-APC }}$ ) (Table 6.1). Because the tissue factor-based APC resistance test in fact measures the amount of thrombin captured by $\alpha 2$-macroglobulin, the

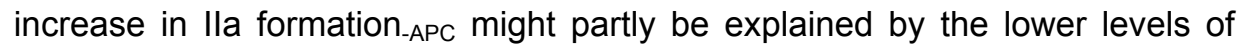
antithrombin in both patient groups. Follow-up of the patients without metastases will demonstrate whether this increased thrombin formation is the first sign of future metastatic disease. Follow-up of all patients will demonstrate whether the resistance to activated protein $\mathrm{C}$ will lead to thromboembolic complications.

In conclusion, in patients with a lymph node positive breast carcinoma with and without known metastatic disease an acquired resistance to APC was found. The APC-sr correlated with protein $S$ in the healthy controls and in patients 
without metastases but not in patients with metastases. The disturbance of the hemostatic balance probed by the tissue factor-based APC resistance test might contribute to the cancer-related hypercoagulability. 


\section{References}

1. Green KB, Silverstein RL. Hypercoagulability in cancer. Hematol Oncol Clin North Am 1996;10(2):499-530.

2. Goad KE, Gralnick HR. Coagulation disorders in cancer. Hematol Oncol Clin North Am 1996;10(2):457-84.

3. Francis $\mathrm{JL}$, Biggerstaff $\mathrm{J}$, Amirkhosravi A. Hemostasis and malignancy. Semin Thromb Hemost 1998;24(2):93-109.

4. Zhang Y, Deng Y, Luther T, Muller M, Ziegler R, Waldherr R, Stern DM, Nawroth PP. Tissue factor controls the balance of angiogenic and antiangiogenic properties of tumor cells in mice. J Clin Invest 1994;94:1320-7.

5. Zacharski LR, Ornstein DL. Heparin and cancer. Thromb Haemost 1998;80:10-23.

6. Shoji M, Hancock WW, Abe K, Micko C, Casper KA, Baine RM, Wilcox JN, Danave I, Dillehay DL, Matthews E, Contrino J, Morrissey JH, Gordon S, Edgington TS, Kudryk B, Kreutzer DL, Rickles FR. Activation of coagulation and angiogenesis in cancer. Immunohistochemical localization in situ of clotting proteins and vascular endothelial growth factor in human cancer. Am J Pathol 1998;152:399-411.

7. Sörensen HT, Mellemkjaer L, Steffensen FH, Olsen JH, Nielsen GL. The risk of a diagnosis of cancer after primary deep venous thrombosis or pulmonary embolism. N Engl J Med 1998;338:1169-73.

8. Baron JA, Gridley G, Weiderpass E, Nyrén O, Linet M. Venous thromboembolism and cancer. Lancet 1998;351:1077-80.

9. Kakkar AK, DeRuvo N, Chinswangwatanakul V, Tebbutt S, Williamson RCN. Extrinsic-pathway activation in cancer with high factor VIla and tissue factor. Lancet 1995;346:1004-5.

10. Dahlback B, Carlsson M, Svensson PJ. Familial thrombophilia due to a previously unrecognized mechanism characterized by poor anticoagulant response to activated protein C: prediction of a co-factor to activated protein C. Proc Nat Acad Sci USA 1993;90:1004-8.

11. Griffin JH, Evatt B, Wideman C, Fernandez JA. Anticoagulant protein C pathway defective in majority of thrombophilic patients. Blood 1993;82:1989-93

12. Koster T, Rosendaal FR, de Ronde H, Briet E, Vandenbroucke JP, Bertina RM. Venous thrombosis due to poor anticoagulant response to activated protein $\mathrm{C}$ : Leiden Thrombophilia Study. Lancet 1993;342:1503-6.

13. De Visser MC, Rosendaal FR, Bertina RM. A reduced sensitivity for activated protein $\mathrm{C}$ in the absence of factor $\mathrm{V}$ Leiden increases the risk of venous thrombosis. Blood 1999;93:1271-6.

14. Rodeghiero F, Tosetto A. Activated protein $C$ resistance and factor $V$ Leiden mutation are independent risk factors for venous thromboembolism. Ann Intern Med 1999;130:643-50.

15. Rosing J, Tans G, Nicolaes GAF, Thomassen MCLGD, van Oerle R, van der Ploeg PMEN, Heijnen P, Hamulyak K, Hemker HC. Oral contraceptives and venous thrombosis: different sensitivities to activated protein $\mathrm{C}$ in women using secondand third-generation oral contraceptives. Br J Haematol 1997;97:233-8.

16. Curvers J, Thomassen MCLGD, Nicolaes GAF, van Oerle R, Hamulyak K, Hemker HC, Tans G, Rosing J. Acquired APC resistance and oral contraceptives: differences between two functional tests. Br J Haematol 1999;105:88-94. 
17. Rosing J, Middeldorp S, Curvers J, Thomassen MCLGD, Nicolaes GAF, Meijers JCM, Bouma BN, Büller HR, Prins MH, Tans G. Low-dose oral contraceptives and acquired resistance to activated protein $\mathrm{C}$ : a randomised cross-over study. Lancet 1999;354:2036-40.

18. Green D, Maliekel K, Sushko E, Akhtar R, Soff GA. Activated protein C resistance in cancer patients. Haemostasis 1997;27:112-8.

19. Haim N, Lanir N, Hoffman R, Haim A, Tsalik M, Brenner B. Acquired activated protein $C$ resistance is common in cancer patients and is associated with venous thromboembolism. Am J Med 2001;110:91-6.

20. Costantini V, De Monte P, Cazzato AO, Stabile AM, Deveglia R, Frezzato E, Paolucci MC. Systemic thrombin generation in cancer patients is correlated with extrinsic pathway activation. Blood Coagul Fibrinolysis 1998;9:79-84.

21. Nijziel MR, van Oerle R, Thomassen MCLGD, Hamulyák K, Tans G, Rosing J. Acquired resistance to activated protein $\mathrm{C}$ in breast cancer patients. Thromb Haemost 1999; suppl:311(A980).

22. Griffin JH, Evatt B, Zimmerman TS, Kleiss AJ, Wideman C. Deficiency of protein C in congenital thrombotic disease. J Clin Invest 1981;68:1370-3.

23. Schwarz HP, Fischer M, Hopmeier P, Batard MA, Griffin JH. Plasma protein S deficiency in familial thrombotic disease. Blood 1984;64:1297-1300.

24. World Health Organization Collaborative Study of Cardiovascular Disease and Steroid Hormone Contraception. Venous thromboembolic disease and combined oral contraceptives: results of international multicentre case-control study. Lancet 1995;346(8990):1575-82.

25. Middeldorp S, Meijers JCM, van den Ende AE, van Enk A, Bouma BN, Tans G, Rosing $\mathrm{J}$, Prins $\mathrm{MH}$, Büller HR. Effect on coagulation of levonorgestrel- and desogestrel-containing low dose oral contraceptives: a cross-over study. Thromb Haemost 2000;84:4-8.

26. Tans G, Curvers J, Middeldorp S, Thomassen MCLGD, Meijers JCM, Prins MH, Bouma BN, Büller HR, Rosing J. A randomized cross-over study on the effects of levonorgestrel- and desogestrel-containing oral contraceptives on the anticoagulant pathways. Thromb Haemost 2000;84:15-21.

27. Winkler UH. Hemostatic effects of third- and second-generation oral contraceptives: absence of a causal mechanism for a difference in risk of venous thromboembolism. Contraception 2000;62(2):S11-S20 


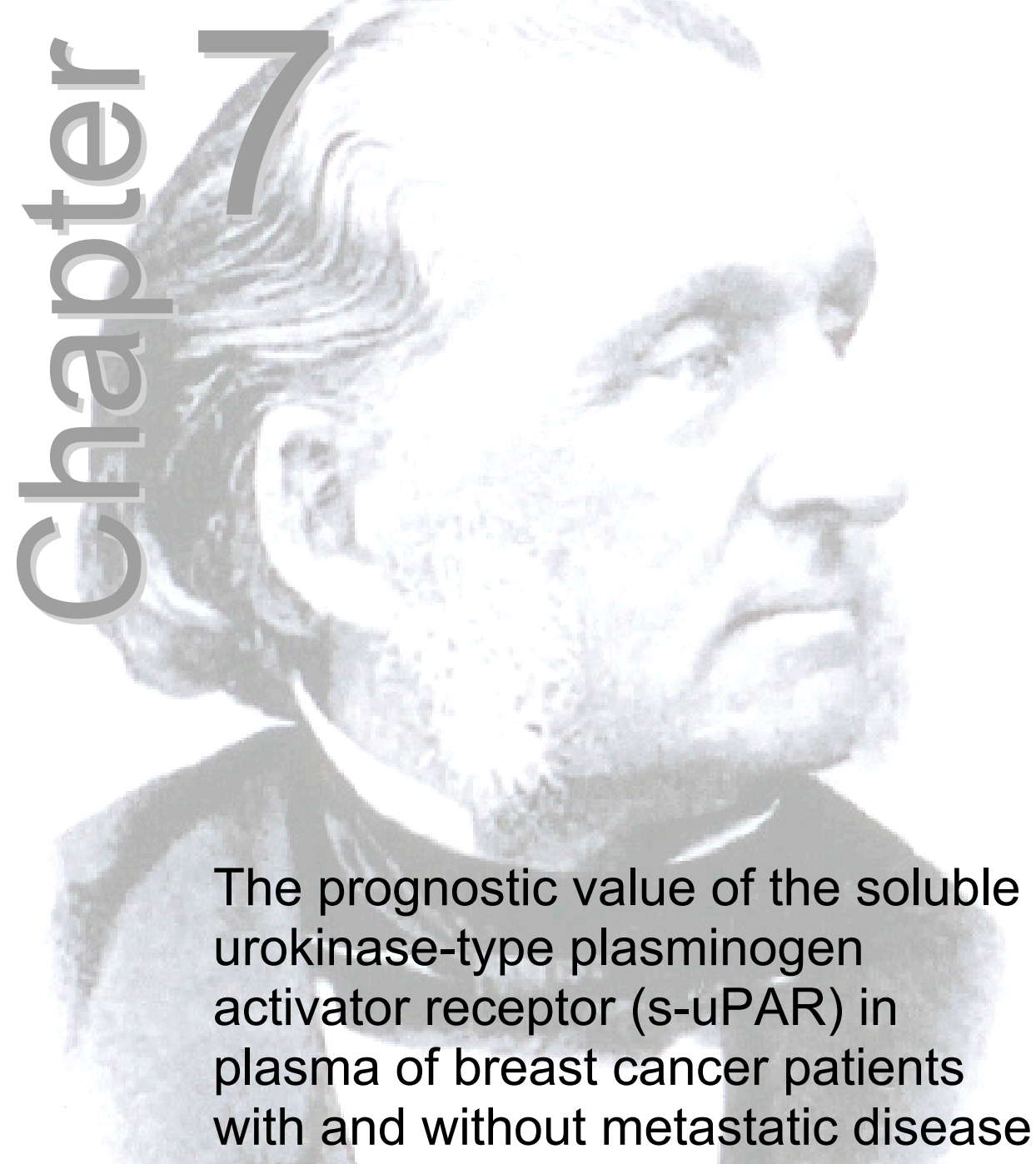

Marten R Nijziel, René van Oerle, Dave Hellenbrand,

Elisabeth CM van Pampus, Harry FP Hillen, Karly Hamulyák

J Thromb Haemost 2003;1:982-6 


\section{Summary}

Elevated levels of soluble UPAR (s-uPAR) and other fibrinolytic parameters functionally related to the urokinase-type plasminogen activator system might indicate the presence of cancer cells. In 25 breast cancer patients with metastases S-UPAR was significantly increased compared to 25 patients without metastases and to 25 healthy controls: $420 \mathrm{pg} / \mathrm{ml}$ vs. $145 \mathrm{pg} / \mathrm{ml}$ $(p=0.005)$ and $190 \mathrm{pg} / \mathrm{ml} \quad(p=0.003)$. Plasmin-alpha2-antiplasmin (PAP) complexes and D-dimers were significantly increased in breast cancer patients with metastases compared to patients without metastases and to healthy controls. The levels of PAI-1 activity, uPA antigen and factor Xlla did not significantly differ between the patient groups and the healthy controls. PAP-complexes ( $529 \mu \mathrm{g} / \mathrm{l}$ vs. $420 \mu \mathrm{g} / \mathrm{l} ; \mathrm{p}=0.03)$, D-dimers $(278.5 \mathrm{ng} / \mathrm{ml}$ vs. 79.0 $\mathrm{ng} / \mathrm{ml} ; \mathrm{p}=0.005)$ and factor Xlla $(1.64 \mathrm{ng} / \mathrm{ml}$ vs. $1.19 \mathrm{ng} / \mathrm{ml} ; \mathrm{p}=0.01)$ were significantly higher in the patients with metastases not surviving compared to the patients with metastases surviving the three-year follow-up period. Plasma s-uPAR levels in the patients with metastases did not discriminate between the patients surviving and the patients not surviving after three-year follow-up. No significant differences in s-UPAR or any of the other parameters were found in the five patients developing metastases during follow-up. We postulate that a single value of s-uPAR is of limited value in the follow-up breast cancer patients with and without metastatic disease. 


\section{Introduction}

The migration of cancer cells from the primary tumor and the invasion of cancer cells in the surrounding tissue are early steps in the process of cancer metastasis ${ }^{1}$. It has been demonstrated that the fibrinolytic system, in particular the urokinase-type plasminogen activator system, is involved in this process of tumor cell invasion and metastasis. Urokinase-type plasminogen activator (UPA) binds to the urokinase-type plasminogen activator receptor (UPAR), among others present on tumor cells and monocytes, thus facilitating the conversion of plasminogen to plasmin. Plasmin is a protease able to degrade the extracellular matrix directly or indirectly by activating matrix metalloproteinases. These matrix metalloproteinases degrade collagen and other matrix proteins, thereby allowing tumor cells and monocytes to invade the extracellular matrix and the surrounding tissues. The activity of UPA and UPAR is inhibited by specific inhibitors, plasminogen activator inhibitor (PAI) 1 and 2 . Plasmin is inactivated by alpha-2-antiplasmin with the formation of plasminalpha-2-antiplasmin (PAP) complexes ${ }^{2-4}$.

It has been shown that elevated tumor levels of UPA, UPAR and PAI-1 are associated with poor prognosis in various malignancies, including cancers of the lung, stomach, colorectum, bladder, ovary and breast ${ }^{1}$. Breast cancer patients with high tumor levels of UPA had a significant shorter disease-free and overall survival ${ }^{5-9}$. The tumor uPA level is a strong prognostic marker in node-positive as well as node-negative breast cancer patients ${ }^{10,11}$. High tumor levels of UPAR were also associated with shorter disease free and overall survival, particularly in the subgroup of node-positive postmenopausal women $^{12,13}$. Tumor PAl-1 was a strong independent prognostic factor and an important parameter to predict metastatic potential in both node-negative and node-positive human primary breast cancer ${ }^{9,14,15}$. On the contrary, elevated tumor PAI-2 levels have been associated with favorable prognosis ${ }^{16,17}$.

So far mainly UPAR levels in tumor tissue homogenates and cytosolic extracts have been studied. It has been suggested that soluble uPAR (s-uPAR) levels in plasma reflect local expression and release of $U P A R^{13,18}$. Thus, the levels of S-UPAR in the plasma of cancer patients could be a valuable marker for local expression of UPAR on tumor cells or monocytes that are involved in metastasis. Indeed it has been demonstrated that in stage IV breast cancer patients s-uPAR levels in plasma are significantly increased ${ }^{19}$. Recently it has been shown that high preoperative s-uPAR levels are significantly associated with poor outcome in breast cancer patients independent of lymph node status, tumor size and estrogen receptor status ${ }^{20}$. Until now s-uPAR levels have not been studied in patients with a breast carcinoma during follow-up after their initial treatment with surgery, radiotherapy and chemotherapy. 
Therefore we studied s-uPAR levels in patients with a breast carcinoma in plasma samples collected during follow-up after the primary treatment with surgery, radiotherapy and chemotherapy. At the same time we studied other fibrinolytic parameters functionally related to the urokinase-type plasminogen activator system. We hypothesized that in patients without known metastases elevated levels are parameters for future metastatic disease and consequently could have clinical implications. We also hypothesized that in patients with known metastases elevated levels are inversely correlated with survival. All patients were prospectively followed for three years.

\section{Materials and methods}

\section{Patients}

Twenty five consecutive patients with a breast carcinoma with proven metastases, 25 consecutive women with a breast carcinoma without metastases and 25 healthy female controls were studied. All breast cancer patients were collected from the outpatient clinic during follow-up after a history of a TxN1M0 tumor treated with mastectomy, axillary lymph node dissection and adjuvant systemic chemotherapy. To exclude any effect of chemotherapy on the measurements, patients treated with chemotherapy less than one year before sampling were excluded. The controls were healthy volunteers aged above 45 years not using any medication. In both patient groups, 18 patients used hormonal tumor treatment, seven patients did not use hormonal tumor treatment. In the patients with metastatic disease, the metastases were located in bone (fifteen patients), liver (seven patients), lung (six patients), lymph nodes (four patients), pleura (two patients) and skin (two patients). Ten patients had metastases on multiple locations. None of the patients or controls had (a history of) thromboembolic complications at the start of the study. Of each subject one blood sample was taken between January 1999 and July 1999. The laboratory measurements were done in October 1999. In July 2002, after three years of follow-up, data were analyzed on survival in all groups and on evidence of metastases in the patient group without metastatic disease at the start of the study. All patients and volunteers agreed to participate in the study following informed consent. The study was approved by the Ethical Review Committee of the University Hospital Maastricht.

\section{Blood collection and plasma preparation}

Blood was collected from the antecubital vein without venous stasis using a Vacutainer PrecisionGlide ${ }^{\mathrm{TM}}$ needle $0.8 \times 38 \mathrm{~mm}$ into four $3.15 \mathrm{ml}^{\text {Vacutainer }^{\circledR}}$ tubes containing $0.129 \mathrm{M}$ sodium citrate (both Becton Dickinson Europe, 
France). The first $2 \mathrm{ml}$ were discarded. Citrated platelet poor plasma was made using two centrifuge steps: five minutes $4000 \mathrm{rpm}(2150 \mathrm{~g})$ at room temperature and ten minutes $11000 \mathrm{rpm}(11000 \mathrm{~g})$ at $4^{\circ} \mathrm{C}$. The blood samples were processed within 30 minutes after the collection. The plasma samples were stored at $-70^{\circ} \mathrm{C}$ in aliquots of $500 \mu \mathrm{l}$ until analysis.

\section{Determination of the fibrinolytic parameters}

Soluble uPAR was measured using the IMUBIND ${ }^{\circledR}$ Soluble UPAR ELISA Kit (Product No. 895; American Diagnostica Inc., USA). This ELISA was a kind gift from Instrumentation Laboratory, The Netherlands. UPA was determined using the UPA antigen ELISA from Technoclone, Austria. PAI-1 activity was measured using the Spectrolyse ${ }^{\circledR} / \mathrm{pL}$ PAl from Biopool, Sweden. Plasminalpha-2-antiplasmin complexes were measured by ELISA from Dade/Behring, Germany. Factor XIla was determined using the ELISA kit (product code FAFT200) from Axis-Shield Diagnostics LTD, United Kingdom. D-dimers were measured by TintElize ${ }^{\circledR}$ D-dimer from Biopool. With this assay healthy adults display a mean plasma D-dimer level of $39 \mathrm{ng} / \mathrm{ml}$. The upper reference limit, the 97.5 percentile, is $130 \mathrm{ng} / \mathrm{ml}$. All commercially available assays were carried out according to the manufacturer's instructions.

\section{Statistics}

The data were analyzed using SPSS for Windows version 11.0 (SPSS Inc., Chicago, USA). Non-parametric tests for independent samples were used. To compare the variables in the patient groups and the controls a Mann-Whitney U-test was performed. The differences were considered significant at $p<0.05$. Results are given as medians. Survival was defined as dead vs. alive after the three-year follow-up period. Spearman correlation coefficients were calculated to examine the correlation between the various parameters.

\section{Results}

There were no significant differences in age between the patients with metastases (mean age 59.5 \pm 10.4 years, range 46 to 79 years), the patients without metastases (mean age 56.6 \pm 6.8 years, range 46 to 77 years) and the healthy controls (mean age 58.7 \pm 9.0 years, range 48 to 79 years). In the patients with metastases there was no significant difference in age between patients surviving the three-year follow-up period (mean age 58.9 \pm 9.9 years, range 46 to 75 years) and the patients not surviving the three-year follow-up period ( $59.9 \pm 11.0$ years, range 48 to 79 years). 
In the patients with metastases the median s-uPAR level was significantly higher than in the patients without metastatic disease and in the healthy controls: $420 \mathrm{pg} / \mathrm{ml}$ vs. $145 \mathrm{pg} / \mathrm{ml} \quad(p=0.005)$ and $190 \mathrm{pg} / \mathrm{ml} \quad(p=0.003)$, respectively. No significant differences in s-uPAR were seen between the patients without metastases and the healthy controls (Figure 7.1).

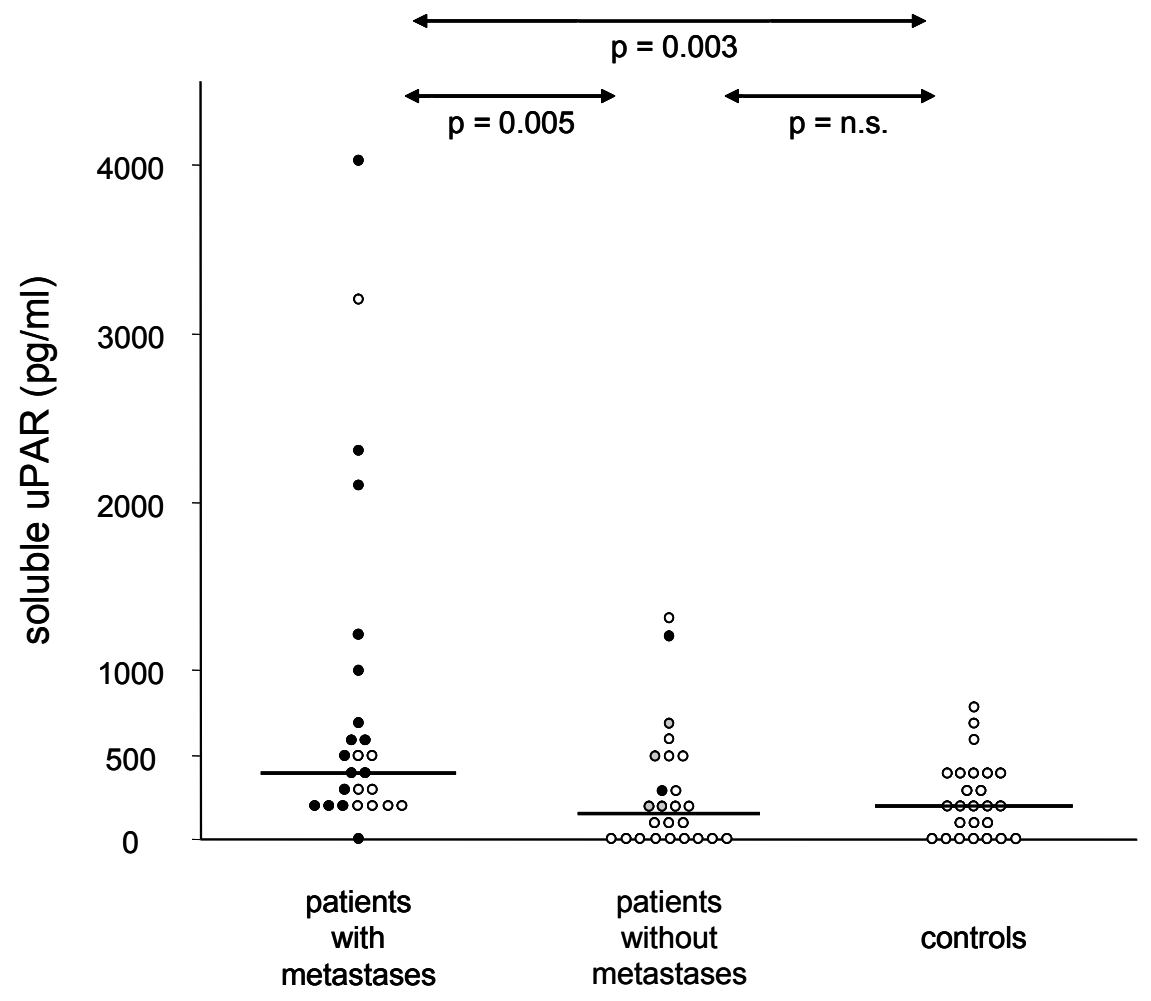

Figure $7.1 \mathrm{~s}-\mathrm{uPAR}$ in $\mathrm{pg} / \mathrm{ml}$ in patients with metastases, patients without metastases and healthy controls; the black dots represent the patients not surviving, the white dots represent the patients surviving and the gray dots represent those patients developing metastases during three year follow-up. 
In the patients with metastases also significantly increased levels of plasminalpha2-antiplasmin (PAP) complexes and D-dimers were found. PAP complexes in the patients with metastases were $454 \mu \mathrm{g} / \mathrm{l} \mathrm{vs.} 301 \mu \mathrm{g} / \mathrm{l}(\mathrm{p}=0.001)$ in the patients without metastases and $282 \mu \mathrm{g} / \mathrm{l}(\mathrm{p}<0.001)$ in the healthy controls. D-dimers in the patients with metastatic disease were $164 \mathrm{ng} / \mathrm{ml}$ vs. $56 \mathrm{ng} / \mathrm{ml}(p=0.001)$ in the patients without metastases and $52.5 \mathrm{ng} / \mathrm{ml}$ $(p<0.001)$ in the controls (Figure 7.2).

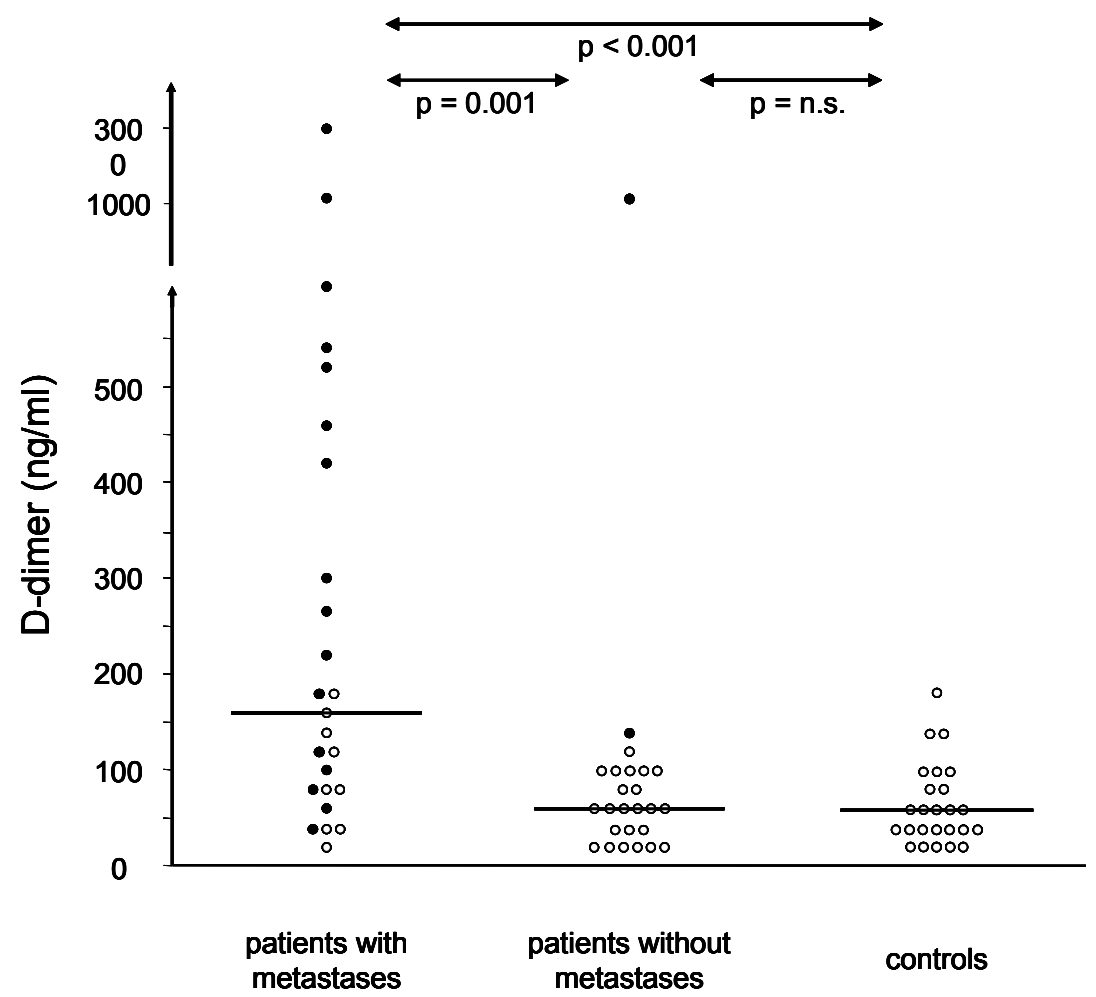

Figure 7.2 D-dimers in $\mathrm{ng} / \mathrm{ml}$ in patients with metastases, patients without metastases and healthy controls; the black dots represent the patients not surviving, the white dots represent the patients surviving the three year follow-up period.

No significant differences were found in levels of PAI-1 activity, uPA antigen and factor XIla (Table 7.1). 
Table 7.1 Parameters of fibrinolysis in breast cancer patients with and without metastases and in healthy controls (median (range)).

\begin{tabular}{lccc}
\hline & $\begin{array}{c}\text { Healthy controls } \\
(\mathrm{n}=25)\end{array}$ & $\begin{array}{c}\text { Patients without metastases } \\
(\mathrm{n}=25)\end{array}$ & $\begin{array}{c}\text { Patients with metastases } \\
(\mathrm{n}=25)\end{array}$ \\
\hline s-uPAR $(\mathrm{pg} / \mathrm{ml})$ & $190(0-760)$ & $145(0-1320)$ & $420(0-4040)^{\mathrm{a}, \mathrm{b}}$ \\
uPA $(\mathrm{ng} / \mathrm{ml})$ & $0.67(0.09-3.20)$ & $0.55(0.12-1.68)$ & $0.75(0.29-1.57)$ \\
PAI-1 $(\mathrm{U} / \mathrm{ml})$ & $8.95(0-27.4)$ & $7.10(0.80-17.0)$ & $8.60(0-38.1)$ \\
PAP $(\mu \mathrm{g} / \mathrm{l})$ & $282(153-483)$ & $301(149-1434)$ & $454(258-1845)^{\mathrm{a}, \mathrm{b}}$ \\
D-dimer $(\mathrm{ng} / \mathrm{ml})$ & $52.5(11.0-177.0)$ & $56.0(21.0-1061.0)$ & $164.0(11.0-3000.0)^{\mathrm{a}, \mathrm{b}}$ \\
Factor XIla $(\mathrm{ng} / \mathrm{ml})$ & $1.26(0.49-3.45)$ & $1.59(0.51-3.24)$ & $1.42(0.38-2.76)$ \\
\hline
\end{tabular}

${ }^{\mathrm{a}}=$ significant differences between patients with metastases and patients without metastases;

${ }^{b}=$ significant differences between patients with metastases and healthy controls.

In the patients with metastases the s-uPAR level was significantly correlated with the PAP complexes: $r=0.43 \quad(p=0.03)$. The PAP complexes were significantly correlated with the D-dimers: $r=0.87(p<0.001)$. No correlation was found between s-uPAR and the UPA antigen or PAI 1 activity.

During the three-year follow-up period, of the 25 patients with metastases sixteen $(64 \%)$ died of progressive disease. In the patient group without metastases overall survival was $92 \%$ (23 of 25 patients). In this group one patient died of progressive disease with metastases in the liver, the other died after a cardiac arrest without evidence of disseminated breast cancer. In the patient group with proven metastases the patients not surviving had a higher s-uPAR compared to the patients surviving, but the difference did not reach significance: $515 \mathrm{pg} / \mathrm{ml}$ vs. $280 \mathrm{pg} / \mathrm{ml}(\mathrm{p}=0.19)$. PAP-complexes, D-dimers and factor XIla levels all were significantly higher in the patients not surviving compared to the patients surviving: PAP complexes $529 \mu \mathrm{g} / \mathrm{l} \mathrm{vs}$. $420 \mu \mathrm{g} / \mathrm{l}(\mathrm{p}=0.03)$, D-dimers $278.5 \mathrm{ng} / \mathrm{ml}$ vs. $79.0 \mathrm{ng} / \mathrm{ml}(\mathrm{p}=0.005)$ and factor XIla $1.64 \mathrm{ng} / \mathrm{ml}$ vs. $1.19 \mathrm{ng} / \mathrm{ml}(\mathrm{p}=0.01)($ Table 7.2$)$.

Table 7.2 Parameters of fibrinolysis in breast cancer patients with known metastases not surviving during three years of follow-up compared to patients surviving (median (range))

\begin{tabular}{lccc}
\hline & $\begin{array}{c}\text { Patients with metastases } \\
\text { surviving } \\
(\mathrm{n}=9)\end{array}$ & $\begin{array}{c}\text { Patients with metastases } \\
\text { not surviving } \\
(\mathrm{n}=16)\end{array}$ & $\mathrm{p}$-value \\
\hline S-UPAR $(\mathrm{pg} / \mathrm{ml})$ & $280(160-3170)$ & $515(0-4040)$ & 0.19 \\
uPA $(\mathrm{ng} / \mathrm{ml})$ & $0.79(0.29-1.39)$ & $0.69(0.31-1.57)$ & 0.68 \\
PAl-1 $(\mathrm{U} / \mathrm{ml})$ & $5.90(0-24.70)$ & $10.40(3.20-38.10)$ & 0.17 \\
PAP $(\mu \mathrm{g} / \mathrm{l})$ & $420(258-702)$ & $529(294-1845)$ & $0.03^{\mathrm{a}}$ \\
D-dimer $(\mathrm{ng} / \mathrm{ml})$ & $79.0(11.0-186.0)$ & $278.5(50.0-3000.0)$ & $0.005^{\mathrm{a}}$ \\
Factor XIla $(\mathrm{ng} / \mathrm{ml})$ & $1.19(0.38-2.38)$ & $1.64(0.58-2.76)$ & $0.01^{\mathrm{a}}$ \\
\hline
\end{tabular}

${ }^{a}=$ significant differences between patients not surviving and patients surviving 
During the three-year follow-up period, of the 25 patients without metastases five $(20 \%)$ developed metastatic disease (Figure 7.1$)$. There were no significant differences between the five patients who developed metastases and the twenty patients without progression in terms of the laboratory parameters evaluated in this study.

\section{Discussion}

Many studies in breast cancer patients have demonstrated that increased tumor levels of UPA, UPAR and PAI-1 are associated with decreased disease free and overall survival, suggesting progressive or disseminated disease $e^{4-17}$. However, the relevance of blood levels of these components is less clear. Our study is the first measuring S-UPAR in plasma of patients with a breast carcinoma during follow-up after their initial treatment with surgery, radiotherapy and chemotherapy.

This study confirms the finding of increased levels of s-uPAR in breast cancer patients with metastatic disease compared to patients without metastases and healthy controls ${ }^{19,20}$. There were no significant differences in plasma levels of PAI-1 and UPA between patients with metastases, patients without metastases and controls. No correlation was found between the s-uPAR, UPA and PAI-1 in the patients with metastases. These results suggest a local activity and release of UPAR without a concomitant increase in plasma uPA or decrease in plasma PAI-1. Nevertheless plasmin is being formed as demonstrated by the elevated PAP-complexes in the patients with metastases. An obvious explanation is that locally tumor derived UPA binds to the UPAR facilitating the conversion of plasminogen to plasmin. The correlation between s-uPAR and the PAPcomplexes is in line with this suggestion.

In our study plasma s-uPAR levels measured during follow-up in breast cancer patients with metastases did not discriminate between the patients surviving and the patients not surviving the three-year follow-up period. Also, plasma s-uPAR levels were not significantly correlated with overall survival. This is in contrast with previous observations of tumor levels of uPAR. High tumor levels of UPAR have been associated with a shorter disease free and overall survival, particularly in node-positive postmenopausal women ${ }^{12,13}$. Our results suggest that the clinical significance of plasma s-uPAR is different from tumor uPAR.

High preoperative serum levels of s-uPAR in breast cancer patients have been associated with decreased relapse free and overall survival ${ }^{20}$. We have obtained our samples postoperatively after previous mastectomy, axillary lymph node dissection, radiotherapy and adjuvant chemotherapy. Our results did not demonstrate any association with relapse free or overall survival, suggesting that preoperative s-uPAR levels, with the primary tumor present ${ }^{20}$, 
differ from the postoperative s-uPAR levels during follow-up after the initial treatment.

This study shows interesting results of two other factors functionally related to the urokinase-type plasminogen activator system, namely factor XIla and the D-dimers. Factor XIla is a kinetically favorable plasminogen activator with an efficiency equivalent to urokinase ${ }^{21}$. By facilitating the conversion of plasminogen into plasmin, factor XIla can substantially contribute to cancer cell invasion and dissemination. Increased levels of factor XIla have been reported in patients with advanced solid tumors ${ }^{22}$. The significantly elevated factor XIla levels in the patients with metastases not surviving during the three-year followup period compared with those surviving, and the significant correlation with survival suggest a role of factor XIla in progression of disease. However, in patients with metastases the levels of factor XIla did not differ from the levels in patients without metastases. This limits the use of factor XIla for the early detection of metastases during follow-up.

Elevated D-dimer levels, indicating the degradation of fibrin by the fibrinolytic system, have been described before in breast cancer patients as well as in various other cancers ${ }^{23}$. Recently it has been demonstrated that in breast cancer patients preoperative plasma D-dimer levels correlate with clinical stage and axillary lymph node status ${ }^{24}$. Moreover, in patients with metastatic breast cancer plasma D-dimer levels correlated with tumor volume, progression rate and survival ${ }^{25}$.

Plasma D-dimer levels were significantly elevated in the breast cancer patients with metastases compared to patients without metastases. More interesting, Ddimer levels were more than a threefold increased in the patients not surviving compared to those surviving (Table 7.2) and therefore highly significant correlated with survival. The twelve patients with the highest D-dimer levels all did not survive, including one patient in the patient group without metastases at the time of drawing the blood samples (Figure 7.2). This patient with a significantly increased D-dimer level developed liver metastases 24 months later and died of progressive disease after 30 months. The elevated D-dimer level could have been the first sign of metastatic disease. Our results are in line with previous reports ${ }^{21-26}$ and suggest that the D-dimer level is more promising than the s-uPAR level in the detection of progressive or disseminated disease. However, in this study neither s-UPAR nor D-dimers could predict metastatic disease in the patient group without metastases, probably due to the low number of patients developing metastases during the three-year follow-up period.

The conclusion whether or not s-UPAR can be used to predict survival or metastatic disease in breast cancer patients during follow-up should be based on sequential values rather than on a single sample. However, the results of our study might suggest that other tests, as tumor levels of UPAR and plasma 
levels D-dimer are more promising. Currently a prospective study with sequential values of s-uPAR in the follow-up of breast cancer patients is being performed.

In conclusion, soluble UPAR and other components of the urokinase-type plasminogen activator system have been suggested to play a pivotal role in cancer cell invasion en dissemination. Although s-uPAR levels in plasma are significantly increased in breast cancer patients with metastatic disease, s-uPAR levels did not predict survival, contrary to elevated tumor levels of UPAR and plasma levels of factor XIla and D-dimer. Increased s-uPAR levels were no indication of future metastatic disease in patients without metastases at the time of sampling. A single value of s-uPAR is of limited value in the follow-up breast cancer patients with and without metastatic disease. 


\section{References}

1. Andreasen PA, Kjøller L, Christensen L, Duffy MJ. The urokinase-type plasminogen activator system in cancer metastasis: a review. Int $\mathrm{J}$ cancer 1997; 72:1-22.

2. Schmitt M, Harbeck N, Thomssen C, Wilhelm O, Magdolen V, Reuning U, Ulm K, Höfler $\mathrm{H}$, Jänicke $\mathrm{F}$, Graeff $\mathrm{H}$. Clinical impact of the plasminogen activation system in tumor invasion and metastasis: prognostic relevance and target for therapy. Thromb Haemost 1997;78(1):285-96.

3. Mondino A, Resnati M, Blasi F. Structure and function of the urokinase receptor. Thromb Haemost 1999; 82 (suppl): 19-22.

4. Foekens JA, Peters HA, Look MA, Portengen H, Schmitt M, Kramer MD, Brünner N, Jänicke F, Meijer-van Gelder ME, Henzen-Logmans SC, van Putten WLJ, Klijn JGM. The urokinase system of plasminogen activation and prognosis in 2780 breast cancer patients. Cancer Res 2000;60:636-43.

5. Duffy MJ, O'Grady P, Devaney D, O'Siorain L, Fennelly JJ, Lijnen HJ. Urokinaseplasminogen activator, a marker for aggressive breast carcinomas. Preliminary report. Cancer 1988;62(3): 531-3.

6. Jänicke F, Schmitt M, Ulm K, Gössner W, Graeff H. Urokinase-type plasminogen activator antigen and early relapse in breast cancer. Lancet 1989;2(8670):1049.

7. Duffy MJ, Reilly D, O'Sullivan C, O'Higgins N, Fennelly JJ, Andreasen P. Urokinase-plasminogen activator, a new and independent prognostic marker in breast cancer. Cancer Res 1990;50:6827-9.

8. Jänicke F, Schmitt M, Hafter R, Hollrieder A, Babic R, Ulm K, Gössner W, Graeff H. Urokinase-type plasminogen activator ( $\mathrm{u}-\mathrm{PA})$ antigen is a predictor of early relapse in breast cancer. Fibrinolysis 1990;4:69-78.

9. Grøndahl-Hansen J, Christensen IJ, Rosenquist C, Brünner N, Mouridsen HT, Danø K, Blichert-Toft M. High levels of urokinase-type plasminogen activator and its inhibitor PAI-1 in cytosolic extracts of breast carcinomas are associated with poor prognosis. Cancer Res 1993;53:2513-21.

10. Foekens JA, Schmitt M, van Putten WLJ, Peters HA, Bontenbal M, Jänicke F, Klijn JGM. Prognostic value of urokinase-type plasminogen activator in 671 primary breast cancer patients. Cancer Res 1992;52:6101-5.

11. Look MP, van Putten WL, Duffy MJ, Harbeck N, Christensen IJ, Thomssen C, Kates R, Spyratos F, Ferno M, Eppenberger-Castori S, Sweep CG, UIm K, Peyrat JP, Martin PM, Magdelenat H, Brunner N, Duggan C, Lisboa BW, Bendahl PO, Quillien V, Daver A, Ricolleau G, Meijer-van Gelder ME, Manders P, Fiets WE, Blankenstein MA, Broet P, Romain S, Daxenbichler G, Windbichler G, Cufer T, Borstnar S, Kueng W, Beex LV, Klijn JG, O'Higgins N, Eppenberger U, Jänicke F, Schmitt M, Foekens JA. Pooled analysis of prognostic impact of urokinase-type plasminogen activator and its inhibitor PAI-1 in 8377 breast cancer patients. J Natl Cancer Inst 2002;94:116-28.

12. Duggan C, Maguire T, McDermott E, O'Higgins N, Fennelly JJ, Duffy MJ. Urokinase plasminogen activator and urokinase plasminogen activator receptor in breast cancer. Int J Cancer 1995;61:597-600.

13. Grøndahl-Hansen J, Peters HA, van Putten WLJ, Look MP, Pappot H, Rønne E, Danø K, Klijn JGM, Brünner N, Foekens JA. Prognostic significance of the receptor for urokinase plasminogen activator in breast cancer. Clin Cancer Res 1995;1:1079-87. 
14. Jänicke F, Schmitt M, Pache L, Ulm K, Harbeck N, Höffler H, Graeff H. Urokinase plasminogen activator (u-PA) and its inhibitor PAl-1 are strong and independent prognostic factors in node-negative breast cancer. Breast Cancer Res Treat 1993;24:195-208.

15. Foekens JA, Schmitt M, van Putten WLJ, Peters HA, Kramer MD, Jänicke F, Klijn JGM. Plasminogen activator inhibitor-1 and prognosis in primary breast cancer. $\mathrm{J}$ Clin Oncol 1994;12:1648-58.

16. Bouchet C, Spyratos F, Martin PM, Hacene K, Gentile A, Oglobine J. Prognostic value of urokinase-type plasminogen activator (u-PA) and plasminogen activator inhibitors PAl-1 and PAl-2 in breast carcinomas. Br J Cancer 1994;69:398-405.

17. Foekens JA, Buessecker F, Peters HA, Krainick U, van Putten WLJ, Look MP, Klijn JGM, Kramer MD. Plasminogen activator inhibitor-2: prognostic relevance in 1012 patients with primary breast cancer. Cancer Res 1995;55:1423-7.

18. Chavakis T, Willuweit AK, Lupu F, Preissner KT, Kanse SM. Release of soluble urokinase receptor from vascular cells. Thromb Haemost 2001;86:686-93.

19. Stephens RW, Pedersen AN, Nielsen HJ, Hamers MJAG, Høyer-Hansen G, Rønne E, Dybkjær E, Danø K, Brünner N. ELISA determination of soluble urokinase receptor in blood from healthy donors and cancer patients. Clin Chem 1997;43:1868-76.

20. Riisbro R, Christensen IJ, Piironen T, Greenall M, Larsen B, Stephens RW, Han C, Hoyer-Hansen G, Smith K, Brünner N, Harris AL. Prognostic significance of soluble urokinase plasminogen activator receptor in serum and cytosol of tumor tissue from patients with primary breast cancer. Clin Cancer Res 2002;8:1132-41.

21. Schousboe I, Feddersen K, Røjkjær R. Factor XIla is a kinetically favourable plasminogen activator. Thromb Haemost 1999;82:1041-6.

22. Kakkar AK, DeRuvo N, Chinswangwatanakul V, Tebbutt S, Williamson RCN. Extrinsic-pathway activation in cancer with high factor VIla and tissue factor. The Lancet 1995;346:1004-5.

23. Mitter CG, Zielinski CC. Plasma levels of D-dimer: a crosslinked fibrin-degradation product in female breast cancer. J Cancer Res Clin Oncol 1991;117:259-62.

24. Blackwell K, Haroon Z, Broadwater G, Berry D, Harris L, Iglehart JD, Dewhirst M, Greenberg C. Plasma D-dimer levels in operable breast cancer patients correlate with clinical stage and axillary lymph node status. J Clin Oncol 2000;18: 600-8.

25. Dirix LY, Salgado R, Weytjens R, Colpaert C, Benoy I, Huget $P$, van Dam $P$, Prove A, Lemmens J, Vermeulen P. Plasma fibrin D-dimer levels correlate with tumour volume, progression rate and survival in patients with metastatic breast cancer. $\mathrm{Br} \mathrm{J}$ Cancer 2002;86:389-95.

26. Beer JH, Haeberli A, Vogt A, Woodtli K, Henkel E, Furrer Th, Fey MF. Coagulation markers predict survival in cancer patients. Thromb Haemost 2002;88:745-9. 


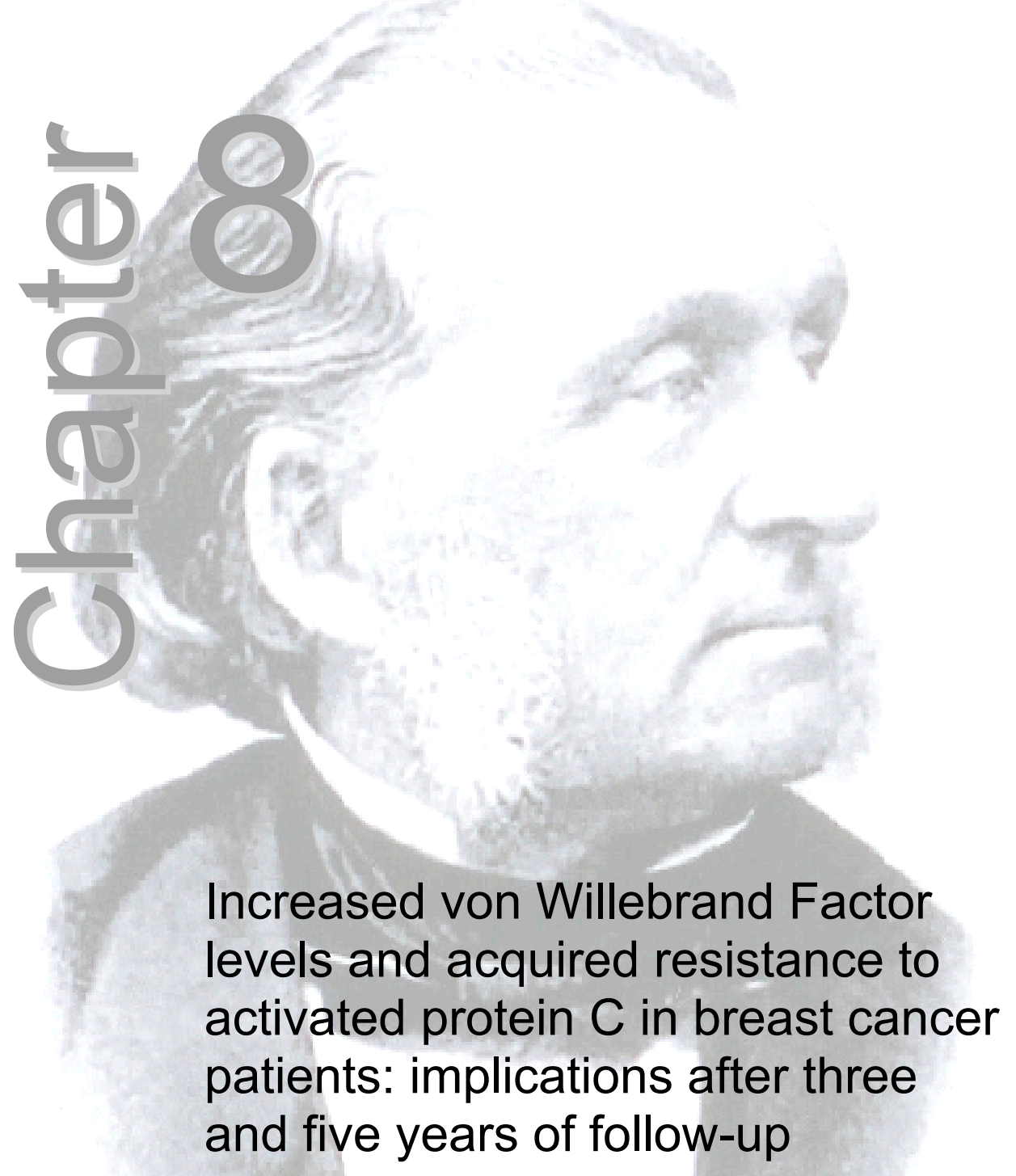

Marten R Nijziel, René van Oerle, Harry FP Hillen, Guido Tans, Jan Rosing, Karly Hamulyák 


\section{Summary}

Tumor cells need the endothelium, endothelial proteins and the coagulation system for their growth and dissemination. Important components in this interaction of coagulation and tumor growth are the von Willebrand Factor (vWF) and resistance to activated protein C. The objective of this study was to determine whether increased von Willebrand Factor and/or acquired resistance to activated protein $C$ are predictive signs of future metastatic disease in patients without metastases and indicate more advanced disease and a worse prognosis in patients with metastases. The VWF and APC sensitivity ratios (APC-sr) were measured in 56 breast cancer patients, 28 with metastases and 28 without metastases, and in 28 matched healthy controls. Patients with metastases (153.7\%) and patients without metastases (122.6\%) had a significantly higher vWF than the controls $(107.6 \% ; p<0.001$ and $p=0.05)$. Patients with metastases had a significantly elevated VWF compared with patients without metastases $(p=0.048)$. In patients not surviving three year follow-up vWF was significantly increased compared with patients surviving: 197.8 vs. $131.0 \%$ ( $p=0.003$ ). APC-sr of surviving breast cancer patients was significantly higher than APC-sr of breast cancer patients not surviving three year follow-up: 2.14 vs. $1.40(p=0.017)$. Patients developing a VTE in five year follow-up all had very high vWF levels and APC-sr values at the start of the study. There was no significant difference in vWF and APC-sr between breast cancer patients developing metastases during follow-up and patients who did not. Elevated vWF and APC-sr levels could have implications in the follow-up of breast cancer patients. 


\section{Introduction}

Nowadays we are becoming increasingly aware of the fact that cancer cells interact with the endothelium and the coagulation system for their growth, angiogenesis and dissemination. Many components of the endothelium and the coagulation system are essential in tumor neovascularization and fibrin present in the matrix around tumor cells facilitates tumor cell growth. The increased activation state of the endothelium and the coagulation system induced by tumor cells is a major determinant of the increased risk of thromboembolic complications in cancer patients ${ }^{1,2}$.

In the endothelium many important proteins are synthesized, among others von Willebrand Factor (VWF) and thrombomodulin. The vWF plays a pivotal role in haemostasis by mediating platelet adhesion to the subendothelium after vessel injury and by acting as a carrier protein for coagulation factor $\mathrm{VIII}^{3}$. Of interest is the fact that increased levels of VWF have been reported in patients with breast cancer and various other cancers ${ }^{4-12}$. Experimental models in vitro and in vivo suggest that VWF facilitates binding of platelets to tumor cells, thereby hiding the tumor cells from the immune system and enabling the attachment of tumor cells to the endothelium ${ }^{13}$. Moreover, increased vWF levels have been associated with endothelial cell damage induced by tumor cells, with endothelial cell stimulation by tumor cells and with tumor neovascularization. Increased VWF levels therefore could indicate tumor cell activity in cancer patients.

The endothelial cell membrane glycoprotein thrombomodulin binds thrombin and plays a pivotal role in the thrombin-catalyzed activation of protein $\mathrm{C}$ to the anticoagulant factor activated protein C. Recently we and others have demonstrated that breast cancer patients with and without metastases have an acquired resistance to activated protein $\mathrm{C}^{14-16}$. The mechanism of this acquired resistance to APC is so far unclear. In breast cancer patients with metastases there was a resistance to activated protein $C$ even in the presence of elevated levels of its cofactor protein $\mathrm{S}$, suggesting alterations in the acting components of the delicately balanced protein $C$ pathway ${ }^{16}$. It was hypothesized that acquired resistance to activated protein $\mathrm{C}$ could indicate tumor cell activity in cancer patients.

In this study we prospectively followed breast cancer patients with and without metastases for more than five years. The objective of this study was to see whether elevated levels of VWF and acquired resistance to activated protein C: - indicate more advanced disease and a worse prognosis, - predict future metastatic disease, - and predict thromboembolic complications. 


\section{Materials and methods}

\section{Patients}

Twenty-eight consecutive patients with a breast carcinoma with proven metastases, 28 consecutive women with a breast carcinoma without metastases and 28 healthy female controls were studied. All breast cancer patients were enrolled from the out-patient clinic during follow-up after a history of a TxN1M0 tumor treated with resection, axillary lymph node dissection and adjuvant systemic chemotherapy. To exclude any effect of chemotherapy on the measurements, patients treated with chemotherapy less than one year before sampling were excluded. The controls were healthy volunteers aged above 45 years not using any medication. In both patient groups, 21 patients used hormonal tumor treatment, seven patients did not use hormonal tumor treatment. In the patients with metastatic disease, the metastases were located in bone (15 patients), liver (seven patients), lung (six patients), lymph nodes (four patients), pleura (two patients) and skin (two patients). Ten patients had metastases at multiple locations. None of the patients or controls had (a history of) thromboembolic complications at the start of the study. Carriers of factor $\mathrm{V}$ Leiden, determined by DNA analysis, were excluded. One blood sample was taken from each subject between January 1999 and July 1999. The laboratory measurements were done in November 1999. In July 2002 and in April 2005, after 3 and 5.8 years of follow-up, patient data were analyzed on survival and thromboembolic complications in all groups and on evidence of metastases in the patient group without metastatic disease at the start of the study. All patients and volunteers agreed to participate in the study following informed consent. The study was approved by the Ethical Review Committee of the University Hospital Maastricht.

\section{Blood collection and plasma preparation}

Blood was collected from the antecubital vein without venous stasis using a Vacutainer PrecisionGlide ${ }^{\mathrm{TM}}$ needle $0.8 \times 38 \mathrm{~mm}$ into four $3.15 \mathrm{ml}$ Vacutainer $^{\circledR}$ tubes containing $0.129 \mathrm{M}$ sodium citrate (both Becton Dickinson Europe, France). The first $5 \mathrm{ml}$ were discarded. Citrated platelet poor plasma was obtained after two centrifugation steps: five minutes $4000 \mathrm{rpm}(2150 \mathrm{~g})$ at room temperature and ten minutes $11000 \mathrm{rpm}(11000 \mathrm{~g})$ at $4^{\circ} \mathrm{C}$. The blood samples were processed within 30 minutes after the collection. The plasma samples were stored at $-70^{\circ} \mathrm{C}$ in aliquots of $500 \mu \mathrm{l}$ until analysis.

\section{Determination of von Willebrand Factor and APC-sr}

The von Willebrand Factor Antigen (vWFAg) was measured by ELISA using capture antibody A082 and conjugate P226 both from Dakopatts a/s, Denmark. 
APC sensitivity ratios (APC-sr) were determined with an APC resistance test the principle of which has been described in detail before ${ }^{17,18}$. In short, this assay is based on quantification of the effect of $5 \mathrm{nM}$ APC on thrombin generation initiated in defibrinated platelet poor plasma with $15 \mu \mathrm{M}$ phospholipid vesicles (PS/PE/PC 20/20/60), $0.4 \mathrm{ng} / \mathrm{ml}$ relipidated recombinant tissue factor and $15 \mathrm{mM} \mathrm{CaCl}_{2}$ (final concentrations in plasma). The APC-sr determined by this method shows trends opposite to those determined with the classical APTT-based APC resistance assay. With the method used here a higher APC-sr means a higher resistance to the anticoagulant action of APC (i.e. a lower sensitivity to APC).

\section{Statistics}

The data were analyzed using SPSS for Windows (SPSS Inc., Chicago, USA). Non-parametric tests for independent samples were used. To compare the variables in the patient groups and the controls a Mann-Whitney U-test was performed. The differences were considered significant at a p-value of 0.05 or less. Results are given as medians. Survival was defined as dead vs. alive after the five-year follow-up period. Spearman correlation coefficients were calculated to examine the correlation between the parameters.

\section{Results}

There were no significant differences in age between the patients with metastases (mean age $58.6 \pm 10.2$ years, median age 56.5 years, range 46 to 79 years), the patients without metastases (mean age 55.7 years \pm 6.9 years, median age 54.5 years, range 46 to 77 years) and the healthy controls (mean age $57.8 \pm 9.0$ years, median age 56 years, range 46 to 79 years).

After three years of follow-up 36 of the 56 breast cancer patients $(64.3 \%)$ were alive, ten of the 28 patients with metastases $(35.7 \%)$ and 26 of the 28 patients without metastases $(92.9 \%)$. After more than five years of follow-up 27 of the 56 breast cancer patients (48.2\%) were still alive, four of the 28 patients with metastases $(14.3 \%)$ and 23 of the 28 patients without metastases at the start of the study (82.1\%). Detailed patient characteristics are given in Table 8.1.

In the total group of breast cancer patients VWF was significantly increased compared with the healthy controls: 145.4 vs. $107.6 \%(p=0.001)$. Both the breast cancer patients with metastases (153.7\%) and the breast cancer patients without metastases $(122.6 \%)$ had a significantly higher vWF than the healthy controls $(p<0.001$ and $p=0.05$ respectively). The breast cancer patients with metastases had a significantly elevated VWF compared with the patients without metastases $(p=0.048)$ (Figure 8.1). The vWF in the breast cancer 
patients not surviving the three year follow-up period was significantly increased compared with the breast cancer patients surviving three years: 197.8 vs. $131.0 \%(p=0.003)$. Patients not surviving as well as patients surviving the three year follow-up had a significantly increased vWF compared to the healthy controls $(p<0.001$ and $p=0.038$ respectively). vWF in the breast cancer patients not surviving the five year follow-up period was elevated compared with the breast cancer patients surviving five years: 152.0 vs. $139.1 \%$, but the difference was not statistically significant $(p=0.065)$. Both the patients not surviving and surviving the more than five year of follow-up had a significantly increased vWF compared to the healthy controls $(p<0.001$ and $p=0.042$ respectively).

Table 8.1 Patients characteristics

\begin{tabular}{|c|c|c|c|}
\hline & $\begin{array}{l}\text { Patients with } \\
\text { metastases } \\
(n=28)\end{array}$ & $\begin{array}{l}\text { Patients without } \\
\text { metastases } \\
(n=28)\end{array}$ & $\begin{array}{l}\text { Controls } \\
(n=28)\end{array}$ \\
\hline Age (mean \pm sd years) & $58.6 \pm 10.2$ & $55.7 \pm 6.9$ & $57.8 \pm 9.0$ \\
\hline Female & 28 & 28 & 28 \\
\hline VTE in medical history & 0 & 0 & 0 \\
\hline Hormonal tumor treatment $(n)$ & 21 & 21 & 0 \\
\hline Surviving three years follow-up (n) & $10(35.7 \%)$ & $26(92.9 \%)$ & $28(100 \%)$ \\
\hline Surviving five years follow-up (n) & $4(14.3 \%)$ & $23(82.1 \%)$ & $28(100 \%)$ \\
\hline VTE during follow-up & 3 & 0 & 0 \\
\hline Metastases at start study / during follow-up & $28 / 0$ & $0 / 6$ & $0 / 0$ \\
\hline
\end{tabular}

The results of the APC-sr have been reported previously ${ }^{16}$. To summarize, in the total group of breast cancer patients the median APC-sr was significantly higher compared to the healthy controls: 2.02 vs. $1.03(p<0.001)$. Patients with metastases (1.83) and patients without metastases (2.08) both had a significantly higher APC-sr compared to the healthy controls $(p=0.005$ and $p<0.001$, respectively). The difference in APC-sr between patients with and without metastases was not statistically significant. Contrary to the vWF, the APC-sr of the surviving breast cancer patients was significantly increased compared with the APC-sr of the breast cancer patients not surviving the three year follow-up period: 2.14 vs. $1.40(p=0.017)$. There was a highly significant difference between the APC-sr of patients surviving the three year follow-up period compared with healthy controls $(p<0.001)$, but no statistically significant difference between patients not surviving the three year follow-up period and the healthy controls $(p=0.10)$ (Figure 8.2). There was no difference in APC-sr between both patient groups, non surviving (1.97) and surviving (2.04) the five year follow-up period $(p=0.30)$ but both were significantly higher compared to the healthy controls ( $p=0.003$ and $p<0.001$ respectively) . 


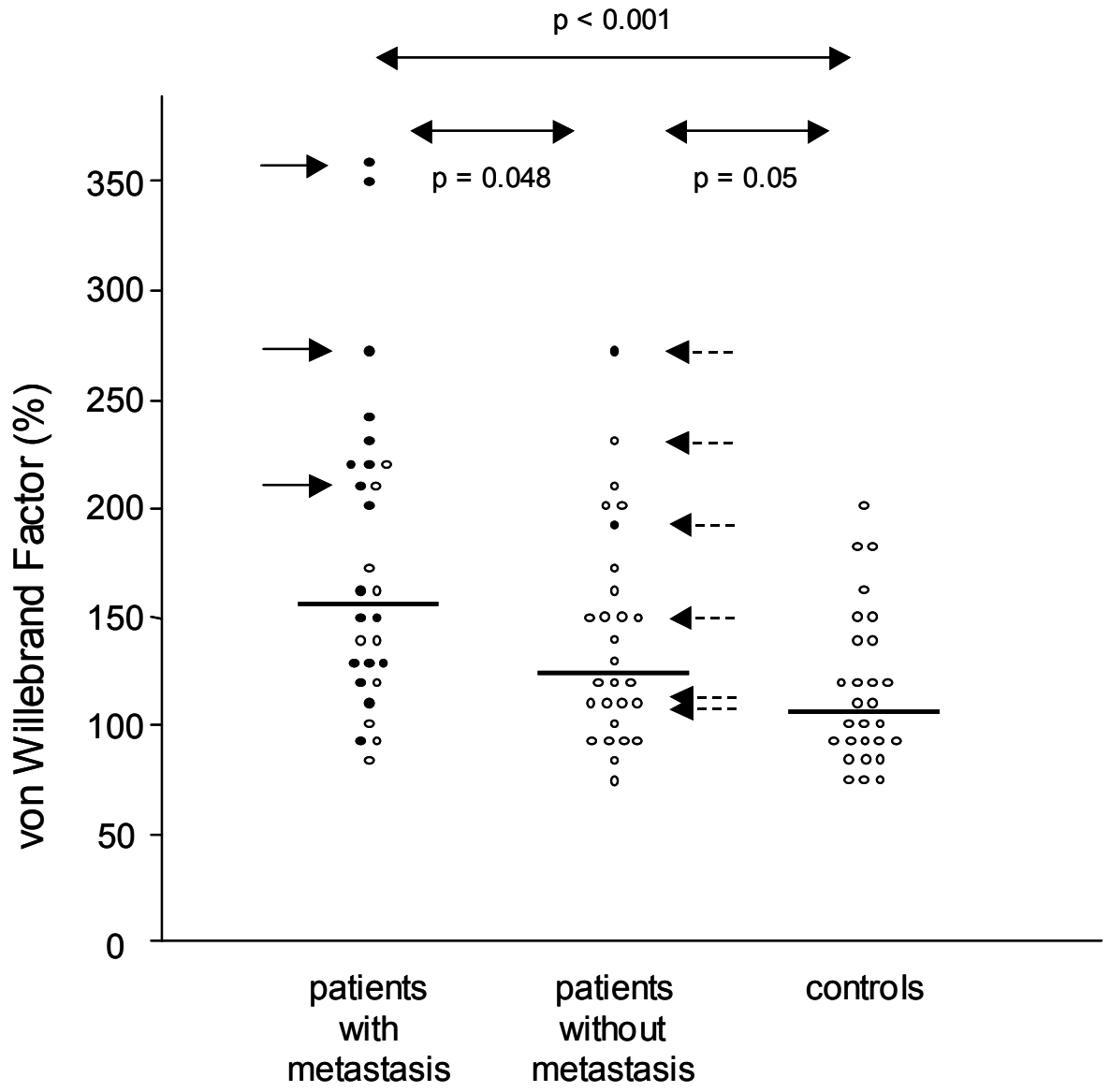

Figure 8.1 The VWF in breast cancer patients with and without metastases compared with agematched healthy controls. The solid lines represent the median vWF. The black dots represent the patients not surviving, the white dots represent the patients surviving three year follow-up. The small uninterrupted arrows indicate the patients developing a VTE in the follow-up period. The small interrupted arrows indicate the patients developing metastases during five year follow-up.

In the patient group with metastases three patients (10.7\%) developed a venous thromboembolism (VTE) during the five year follow-up period. No VTE was documented in the patient group without metastases and in the control group. The three patients developing a VTE in the follow-up period all had very high vWF levels $(209 \%, 273 \%$ and $309 \%$; Figure 8.1$)$ and high APC-sr values $(2.23,2.28$ and 3.29$)$ at the start of the study. 
In the patient group without metastases at the start of the study six patients $(21.4 \%)$ developed metastatic disease, all in the first three years of follow-up (Figure 8.1). Four of these patients died during the five-year follow-up period. There was no significant difference in level of VWF and APC-sr between the breast cancer patients developing metastases during the follow-up and those patients who did not.

Hormonal tumor treatment $(n=42)$ did neither influence vWF levels (145.4 vs. $145.0 \% ; p=0.95)$ nor the APC-sr (2.06 vs. 1.95; $p=0.71)$ in comparison with patients not using hormonal tumor treatment $(n=14)$.

There was no correlation between the vWF and the APC-sr in any of the groups.

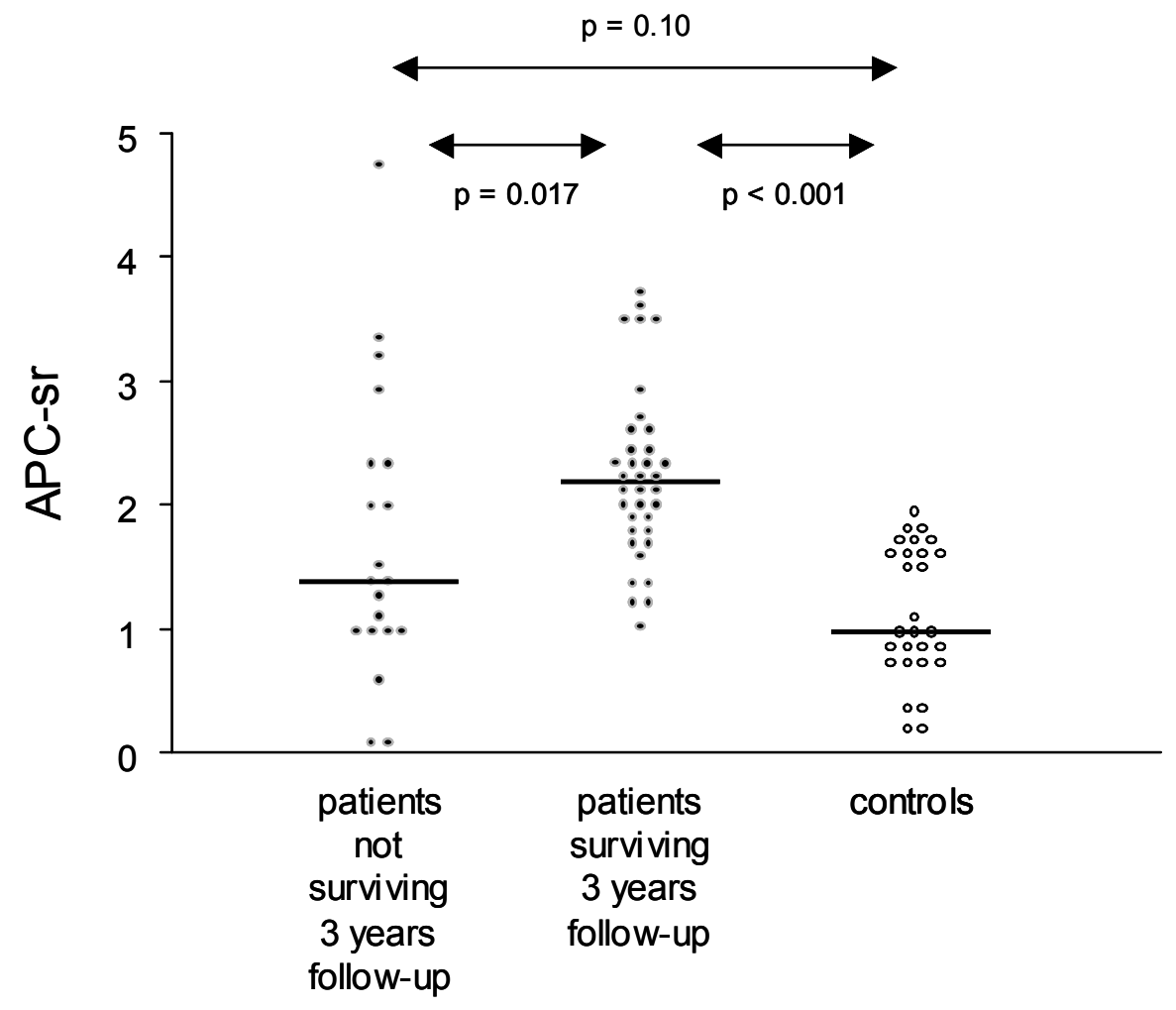

Figure 8.2 APC-sr in breast cancer patients not surviving the three year follow-up period compared with breast cancer patients surviving the three year follow-up period and with agematched healthy control subjects. The solid lines represent the median APC-sr. 


\section{Discussion}

This study shows that VWF levels are significantly increased in plasma of breast cancer patients. Elevated VWF antigen levels have been reported previously in breast cancer, colorectal cancer, carcinoma of the prostate, carcinoma of the bladder, ovarian cancer, cervical cancer, head and neck cancer and in hematological malignancies ${ }^{4-12}$. In colorectal cancer it has been shown that vWF levels are associated with tumor stage, tumor invasion in adjacent organs and metastases ${ }^{7}$. Our study is the first to demonstrate that also in breast cancer vWF levels are discriminating between breast cancer patients with metastases, breast cancer patients without metastases and healthy controls. Moreover, the vWF level was significantly correlated with survival: the patients not surviving the three year follow-up period had a significantly higher VWF than the patients surviving. Of course, patients with metastases had a higher VWF and these patients already have a worse survival by the nature of their disease. However, the fact that the vWF levels in the patient group not surviving the three year follow-up period are higher than in the patient group with metastases and the fact that the significance between the groups after three years is increasing emphasizes that patients with the highest VWF levels have the worst survival. Contrary to other reports we could not demonstrate an effect of hormonal treatment on VWF levels ${ }^{19,20}$.

Together with the data from the literature our observations lead to the key question: is the VWF really important in the growth and dissemination of cancer cells or is it just an epiphenomenon? Indeed, on the one hand VWF is an acute phase reactant that is increased under various (inflammatory) conditions ${ }^{21}$. But, on the other hand it has also been shown that human breast carcinoma tissue expresses the GPIb receptor ${ }^{22}$. This is the receptor that normally binds the vWF to platelets and thus GPIb may also promote the binding of vWF to the tumor cell. It has also been shown that patients with disseminated cancer have a significant increase in unusually large vWF multimers and have a deficiency in VWF cleaving protease ${ }^{23}$. Moreover, patients with cancer and an acute deep venous thrombosis have a higher vWF level than controls with an acute deep venous thrombosis without cancer ${ }^{4}$. This suggests that the acute phase reaction in cancer patients is more pronounced or that this reaction may amplify the increase of the VWF level in these patients. Finally, experimental models suggest that VWF facilitates binding of platelets to tumor cells, thereby protecting them from the immune system and enabling the attachment of tumor cells to the endothelium ${ }^{13}$. In our opinion there are many clues that cancer cells need the vWF, making it unlikely that the increased levels are just an epiphenomenon.

Although APC-sr is significantly increased in breast cancer patients compared to healthy controls, we have previously shown that APC-sr did not discriminate 
patients with metastases and patients without metastases ${ }^{16}$. However, after three years of follow-up there appeared to be a striking increased APC-sr of surviving breast cancer patients compared to the patients not surviving. After five years of follow-up this difference is not seen, possibly related to the low number of patients surviving the five year follow-up period. With the method used a higher APC-sr means a higher resistance to the anticoagulant action of APC and a lower APC-sr a lower resistance to APC, hence a more normal coagulation. A hypothesis is that for its growth and dissemination a tumor in an advanced stage is less dependent on a hypercoagulable state induced by acquired resistance to APC. This is in line with recent reports that LMWH improves survival, but only in the patient groups with the relatively better prognosis ${ }^{24-26}$. Patients with advanced disease had little or no effect of LMWH treatment, also suggesting that these patients are less dependent on a hypercoagulable state. The fact that all patients with a low APC-sr and hence a more normal coagulation in the patient group with metastases did not survive the five year follow-up period supports this suggestion.

Acquired resistance to APC and congenital deficiencies of protein $C$ and protein $S$ are associated with an increased incidence of venous thromboembolism in cancer and non-cancer patients ${ }^{27-30}$. Indeed, three patients developed VTE during the follow-up period. All had very high APC-sr and, interestingly, also very high vWF levels. Although the number of patients was low, we believe that high APC-sr levels and high von Willebrand levels can predict future VTE in breast cancer patients with metastatic disease. Whether this is an indication for prophylactic treatment with anticoagulants, e.g. with low molecular weight heparins (LMWHs), will be subject of further research. Recently it has been shown that LMWHs not only improve survival but also reduce the risk of recurrent VTE in patients with cancer ${ }^{24-26,31}$. We hypothesize that cancer patients with increased APC-sr and VWF levels are in a hypercoagulable state, have a decreased survival, are prone to venous thromboembolic disease and thus could benefit from treatment with LMWHs.

Another aim of the study was to see whether VWF and APC-sr could predict future metastatic disease in patients without metastatic disease at the start of the study. Probably hampered by the relatively small groups, there was no significant difference in VWF and APC-sr between breast cancer patients developing metastases during follow-up and patients who did not. This will be subject of further research in larger studies.

In conclusion, in plasma of breast cancer patients with and without metastases the VWF and APC-sr are significantly increased. We believe that both play a role in tumor growth, angiogenesis and dissemination. Even in these relatively small groups, particularly the vWF was able to discriminate between breast cancer patients with metastases, breast cancer patients without metastases and healthy controls. Patients developing a VTE had very high VWF and APC- 
sr levels. Elevated VWF and APC-sr levels could have implications in the follow-up of breast cancer patients. 


\section{References}

1. Wojtukiewicz MZ, Sierko E, Rak J. Contribution of the hemostatic system to angiogenesis in cancer. Semin Thromb Hemost 2004;30:5-20.

2. Falanga A, Marchetti $M$, Vignoli $A$. Pathogenesis of thrombosis in cancer. In: Thrombosis and Cancer, edited by Lugassy G, Falanga A., Kakkar AK, Rickles FR. Taylor \& Francis 2004, chapter 2, page 11-29.

3. Vlot AJ, Koppelman SJ, Bouma BN, Sixma JJ. Factor VIII and von Willebrand Factor. Thromb Haemost 1998;79:456-65.

4. Goldenberg N, Kahn SR, Solymoss S. Markers of coagulation and angiogenesis in cancer-associated venous thromboembolism. J Clin Oncol 2003;21:4194-9.

5. Röhsig LM, Damin DC, Stefani SD, Castro Jr. CG, Roisenberg I, Schwartsmann G. Von Willebrand factor antigen levels in plasma of patients with malignant breast disease. Braz J Med Biol Res 2001;34:1125-9.

6. Blann AD, Gurney D, Wadley M, Bareford D, Stonelake P, Lip GYH. Increased soluble P-selectin in patients with haematological and breast cancer: a comparison with fibrinogen, plasminogen activator inhibitor and von Willebrand factor. Blood Coagul Fibrinolysis 2001;12:43-50.

7. Damin DC, Rosito M, Gus P, Roisemberg I, Bandinelli E, Schwartsmann G. Von Willebrand factor in colorectal cancer. Int J Colorectal Dis 2002;17:42-5.

8. Ablin RJ, Bartkus JM, Gonder MJ. Immunoquantitation of factor VIII-related antigen (von Willebrand factor antigen) in prostate cancer. Cancer Lett 1988;40:283-9.

9. Zietek Z, Iwan-Zietek I, Paczulski R, Kotschy M, Wolski Z. Von Willebrand factor antigen in blood plasma of patients with urinary bladder carcinoma. Thromb Res 1996;83:399-402.

10. Gadducci A, Baicchi U, Marrai R, Del Bravo B, Fosella PV, Facchini V. Pretreatment plasma levels of fibrinopeptide-A (FPA), D-dimer (DD), and von Willebrand factor (vWF) in patients with ovarian carcinoma. Gynaecol Oncol 1994;53:352-6.

11. Gadducci A, Baicchi U, Marrai R, Facchini V, del Bravo B, Fosella PV, Fioretti P. Pretreatment plasma levels of fibrinopeptide-A (FPA), D-dimer (DD), and von Willebrand factor (VWF) in patients with operable cervical cancer: influence of surgical-pathological stage, tumor size, histological type, and lymph node status. Gynaecol Oncol 1993;49:354-8.

12. Sweeney JD, Killion KM, Pruet CF, Spaulding MB. Von Willebrand factor in head and neck cancer. Cancer 1990;66:2387-9.

13. Nierodzik ML, Klepfish A, Karpatkin S. Role of platelets, thrombin, integrin Ilb-IIla, fibronectin and von Willebrand factor in vitro and metastasis in vivo. Thromb Haemost 1995;74:282-90.

14. Green D, Maliekel K, Sushko E, Akhtar R, Soff GA. Activated protein C resistance in cancer patients. Haemostasis 1997;27:112-8.

15. Haim N, Lanir N, Hoffman R, Haim A, Tsalik M, Brenner B. Acquired activated protein $C$ resistance is common in cancer patients and is associated with venous thromboembolism. Am J Med 2001;110:91-6.

16. Nijziel MR, van Oerle R, Christella M, Thomassen LG, van Pampus EC, Hamulyak $\mathrm{K}$, Tans G, Rosing J. Acquired resistance to activated protein $\mathrm{C}$ in breast cancer patients. Br J Haematol. 2003;120:117-22. 
17. Rosing J, Tans G, Nicolaes GAF, Thomassen MCLGD, van Oerle R, van der Ploeg PMEN, Heijnen P, Hamulyak K, Hemker HC. Oral contraceptives and venous thrombosis: different sensitivities to activated protein $\mathrm{C}$ in women using secondand third-generation oral contraceptives. Br J Haematol 1997:97: 233-8.

18. Curvers J, Thomassen MC, Nicolaes GA, Van Oerle R, Hamulyak K, Hemker HC, Tans G, Rosing J. Acquired APC resistance and oral contraceptives: differences between two functional tests. Br J Haematol 1999;105:88-94.

19. Mannucci PM, Bettega D, Chantarangkul V, Tripoodi A, Sacchini V, Veronesi U. Effect of tamoxifen on measurement of hemostasis in healthy women. Arch Intern Med 1996;156:1806-10.

20. Blann AD, Baildam AD, Howell A, Miller JP. Tamoxifen increases von Willebrand factor in women who underwent breast cancer surgery. Thromb Haemost 2001;85:941-2.

21. Pottinger BE, Read RC, Paleolog EM, Higgins PG, Pearson JD. Von Willebrand factor is an acute phase reactant in man. Thromb Res 1989;53:387-94.

22. Oleksowicz L, Dutcher JP, DeLeon-Fernandez M, Etkind P. A GPIb alpha-related protein is expressed by fresh human breast carcinoma tissue and is regulated by a PKC-sensitive mechanism. Exp Cell Res 1997;237:110-7.

23. Oleksowicz L, Bhagwati N, DeLeon-Fernandez M. Deficient activity of von Willebrand's factor-cleaving protease in patients with disseminated malignancies. Cancer Res 1999;59:2244-50.

24. Klerk CP, Smorenburg SM, Otten HM, Lensing AW, Prins MH, Piovella F, Prandoni $P$, Bos MM, Richel DJ, van Tienhoven G, Buller HR. The effect of low molecular weight heparin on survival in patients with advanced malignancy. $\mathrm{J}$ Clin Oncol 2005;23:2130-5.

25. Lee AY, Rickles FR, Julian JA, Gent M, Baker RI, Bowden C, Kakkar AK, Prins M, Levine MN. Randomized comparison of low molecular weight heparin and coumarin derivatives on the survival of patients with cancer and venous thromboembolism. J Clin Oncol 2005;23:2123-9.

26. Kakkar AK, Levine MN, Kadziola Z, Lemoine NR, Low V, Patel HK, Rustin G, Thomas M, Quigley M, Williamson RCN. Low molecular weight heparin, therapy with dalteparin, and survival in advanced cancer: the Fragmin Advanced Malignancy Outcome Study (FAMOUS). J Clin Oncol 2004;22:1944-8.

27. Griffin JH, Evatt B, Zimmerman TS, Kleiss AJ, Wideman C. Deficiency of protein C in congenital thrombotic disease. J Clin Invest 1981;68:1370-3.

28. Schwarz HP, Fischer M, Hopmeier P, Batard MA, Griffin JH. Plasma protein S deficiency in familial thrombotic disease. Blood 1984;64:1297-1300.

29. Koster T, Rosendaal FR, de Ronde H, Briet E, Vandenbroucke JP, Bertina RM. Venous thrombosis due to poor anticoagulant response to activated protein $\mathrm{C}$ : Leiden Thrombophilia Study. Lancet 1993;342:1503-6.

30. Haim N, Lanir N, Hoffman R, Haim A, Tsalik M, Brenner B. Acquired activated protein $C$ resistance is common in cancer patients and is associated with venous thromboembolism. Am J Med 2001;110:91-6.

31. Lee AY, Levine MN, Baker RI, Bowden C, Kakkar AK, Prins M, Rickles FR, Julian JA, Haley S, Kovacs MJ, Gent M. Randomized Comparison of Low-MolecularWeight Heparin versus Oral Anticoagulant Therapy for the Prevention of Recurrent Venous Thromboembolism in Patients with Cancer (CLOT) Investigators. Lowmolecular-weight heparin versus a coumarin for the prevention of recurrent venous thromboembolism in patients with cancer. N Engl J Med 2003;349:146-53. 


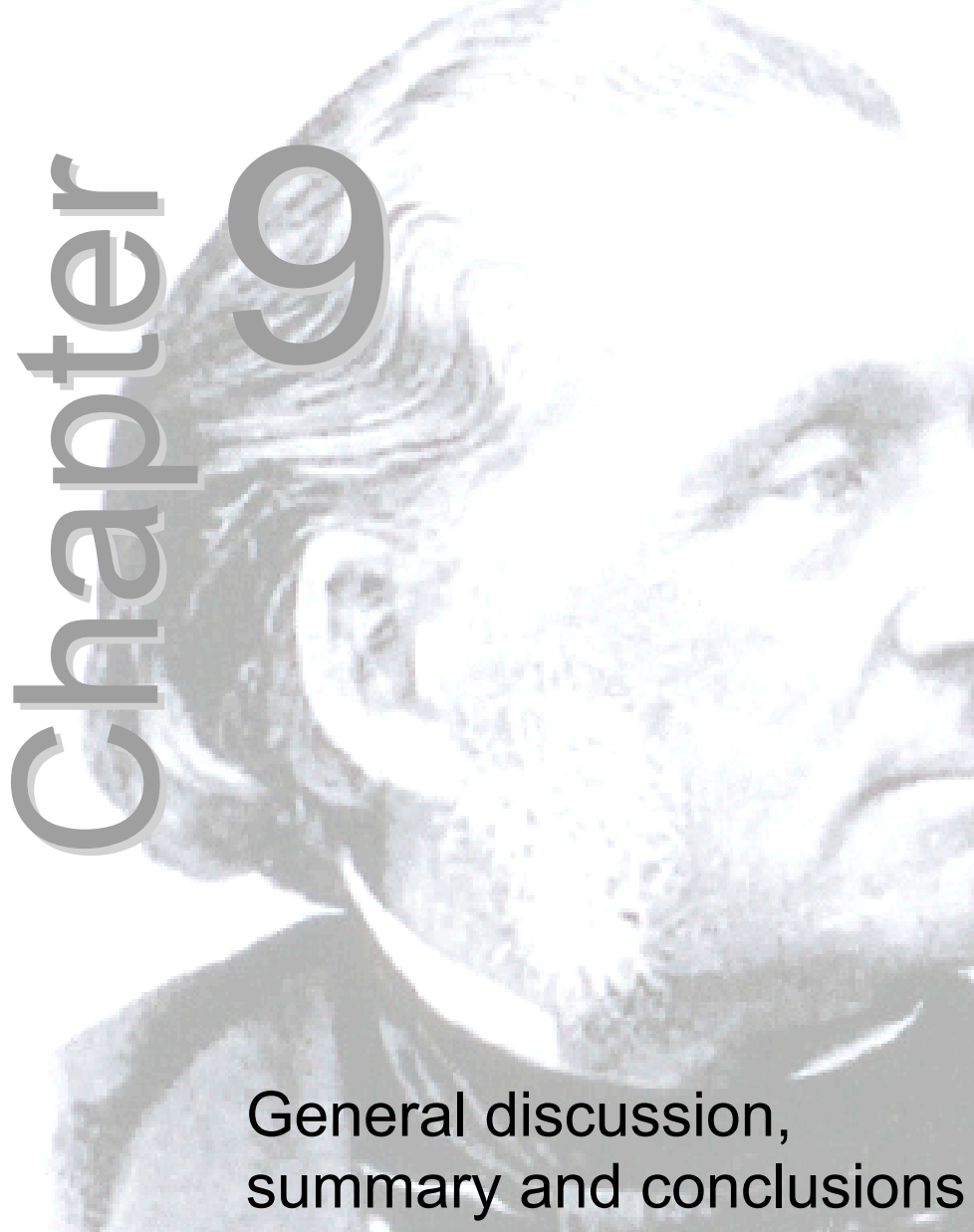




\section{The problem and its challenges}

Although recognized since 1865, the secrets of Trousseau's syndrome and the hypercoagulability in cancer patients, are only slowly revealing themselves. It has become clear that tumor cells use the haemostatic and fibrinolytic system for their growth, formation of new blood vessels and dissemination. Because interfering with this process might inhibit tumor cell growth and dissemination, hypercoagulability in cancer patients is gaining more and more attention. Several research groups are currently investigating the molecular pathofysiology of the activation of the coagulation system by tumor cells. At first this has been mainly a topic for hematologists. However, since it has been demonstrated that anticoagulant treatment with low molecular weight heparin $(\mathrm{LMWH})$ prolongs survival in cancer patients, oncologists have been alerted ${ }^{1-4}$. The survival advantage shown with LMWH seems in selected patients comparable with the survival advantage demonstrated with the very expensive targeted drugs currently used in oncology ${ }^{1}$. In the past oncologists have been very reluctant to use anticoagulant treatment because of the risk of bleeding in their patients and the difficulties keeping cancer patients on stable anticoagulant treatment ${ }^{5}$. However, anticoagulant treatment with LMWH in cancer patients is easy and stable, and the fear of a clinically relevant increase in bleeding problems has not been confirmed in LMWH studies in patients with cancer ${ }^{1-4}$. New studies in different malignancies will follow and will attract more attention of oncologists.

\section{Interfering at the primary point of activation: the pivotal role of tissue factor}

Instead of inhibiting the haemostatic system with LMWH, it might be a better approach to inhibit the process of tumor cells activating the haemostatic system at the primary point of activation. So far tissue factor (TF) has gained a lot of attention as the pivotal step in activating the haemostatic system. TF is the key initiator of the coagulation cascade. Activating the TF pathway eventually leads to the conversion of prothrombin to thrombin and subsequently fibrinogen to fibrin. Fibrin serves as the scaffold for activated endothelial cells in the process of angiogenesis. By directly inhibiting TF it would be possible to prevent the formation of fibrin and hence the matrix for the formation of new blood vessels.

TF is normally only localized in extravascular tissues not directly in contact with the blood stream. In cancer patients however, TF is expressed aberrantly on endothelial cells, monocytes and on tumor cells themselves. It has been demonstrated clearly that in cancer patients tumor cells themselves express $\mathrm{TF}^{6-9}$. This is the simplest and perhaps most important mechanism of a tumor 
cell to directly activate the haemostatic system. Also it has been consistently demonstrated that TF on endothelial cells is induced by cytokines as TNF- $\alpha$ and IL-1 $\beta$ produced by tumor cells ${ }^{10}$. Moreover, these tumor cytokines induce expression of adhesion molecules on endothelial cells, making them capable of attaching to other tumor cells ${ }^{11}$. However, the importance of TF expression on monocytes is less clear. TF on monocytes has been demonstrated in cancer patients mainly in studies in vitro. Isolated monocytes obtained from cancer patients expressed more tissue factor than monocytes from healthy controls after overnight incubation and stimulation with LPS ${ }^{12-14}$. No studies have been performed with directly in vivo measuring the TF expression on monocytes without LPS stimulation. However, many researchers still assume that TF expression on monocytes plays an important role in the cancer-induced hypercoagulability.

\section{Tissue factor on monocytes: does it really play an important role?}

Our studies repeatedly show that in most breast cancer patients TF expression on monocytes and measured TF activity of monocytes is not correlated with activation of the haemostatic system (Chapter 4 and 5). By directly measuring the total amount of monocytes expressing TF in cancer patients we showed that only $10 \%$ of the monocytes express $\mathrm{TF}^{15}$. However, it is known that only $10 \%$ to $20 \%$ of the total extractable TF of a monocyte is expressed on the membrane. The other 80 to $90 \%$ is present inside the monocyte ${ }^{16}$. One way of tackling this problem is measuring TF mRNA in monocytes ${ }^{17}$. We decided to solve this problem by measuring monocyte TF activity in lysed monocytes, thereby measuring the total amount of monocyte TF expressed on the membrane as well as inside the monocyte. A new test was developed, measuring the TF activity in monocytes stimulated by plasma ${ }^{18}$. It has been shown that upon stimulation monocytes of some individuals have a higher monocyte TF activity than monocytes of others, the so called "high and low responder phenomenon"19. This phenomenon has been attributed to effects on monocytes by granulocytes, platelets and LPS, possibly explaining the diffuse intravascular coagulation in serious infections ${ }^{20}$. Because in cancer patients, contrary to infections, LPS is not predominant we measured the MTF activity in monocytes after incubation in a plasma environment depleted of LPS. We showed that in the absence of granulocytes, platelets and LPS, plasma is an important regulator of the monocyte TF activity (Chapter 3 ). By using two subsets of monocytes from healthy volunteers we demonstrated that the plasma determines the TF activity of the monocyte and that both subsets of monocytes reacted similarly ${ }^{18}$. Further research in other subsets of monocytes, 
including those of patients with cancer and various other diseases, showed the same: the monocyte TF activity is much more determined by plasma than by the functional properties of the monocyte itself. Since many changes in plasma proteins have been described in cancer patients ${ }^{21}$, this rendered an interesting research model for testing the influence of plasma of cancer patients, modified by the cancer, on monocytes of healthy volunteers. Although differences in many plasma proteins could be clearly demonstrated, suggesting activation of the haemostatic and fibrinolytic system, we were only able to demonstrate in a small pilot study that the "high and low responder phenomenon" probably also exits in cancer patients (Chapter 5). However, it could not be demonstrated that the cancer plasmas induced more TF in the monocytes than plasma of normal individuals. Moreover, we could not show any correlation of monocyte TF with activation of the coagulation. This suggests that the haemostatic system in cancer patients is activated by other, more important, mechanisms than TF activity of monocytes.

Critics can state that in this plasma stimulated test we did not use the monocytes of the cancer patients themselves. However, we did experiments with monocytes of cancer patients purified by the less selective method of Percoll gradient centrifugation. We tested purified monocytes of various cancer patients, with and without advanced disease, with their own plasma and did cross-over testing with plasma and purified monocytes of healthy controls. We could not find any difference between monocytes of cancer patients and controls (own experiments, data not published). Based on these pilot data we decided that studying a large series of elutriated monocytes obtained from (breast) cancer patients was not useful. Moreover, the time consuming effort of elutriating monocytes of a patient with (advanced) cancer by the method of elutriation as described in the two healthy volunteers was regarded as unethical.

In conclusion, we believe that the data presented seriously throw doubt on the role of monocyte TF expression or TF activity as an initiator of cancer-related hypercoagulability. However, it has recently been shown that TF microparticles are present in a spectrum of cancer patients with a high incidence of thromboembolic complications and that monocytes, endothelial cells and platelets are the most likely sources of this circulating $\operatorname{TF}^{22-24}$. It is possible that monocyte derived TF in cancer patients is present in the microparticle fraction that is not quantified with either of our tests. These particles are too small to be seen by flowcytometry using light scattering and can only be seen by flowcytometry using impedance to measure particle size ${ }^{25}$. By lysing the monocytes and the washing steps that were used, the microparticles were probably washed out. Therefore, TF in the microparticle fraction was probably not measured in the plasma tests. This might explain why we do not measure 
increased monocyte TF expression or monocyte TF activity in cancer patients in our research model.

\section{Haemostatic and fibrinolytic parameters as indicators of tumor activity}

We hypothesized that when a tumor cell is activating the haemostatic and fibrinolytic systems, because these systems are essential for its growth and dissemination, an increase or decrease of certain haemostatic or fibrinolytic factors might indicate the presence and activity of tumor cells. Previously it had been shown that routine coagulation tests as APTT and PT in cancer patients do not differ from normal controls ${ }^{21}$. Therefore, we measured more delicate parameters such as thrombin generation, activated protein C (APC) resistance, the soluble urokinase-type plasminogen activator receptor (s-uPAR), plasminalpha2-antiplasmin (PAP) complexes, factor XII, D-dimers and von Willebrand Factor (VWF) antigen. And indeed we found increased levels of these parameters in breast cancer patients, all indicating or contributing to an activated state of the haemostatic and fibrinolytic systems ${ }^{26-28}$. Having shown that, we prospectively followed these breast cancer patients for more than five years to see whether elevated levels of these parameters were the first signs of future metastatic disease in patients without metastases and to see whether elevated levels implicated more advanced disease and a worse prognosis in patients with metastases.

In patients with a lymph node positive breast carcinoma with and without known metastatic disease an acquired resistance to APC was found (Chapter $6)^{26}$. We measured the sensitivity to activated protein C (APC-sr) with an APC resistance test that quantified the effect of $A P C$ on thrombin generation initiated via the extrinsic coagulation pathway, since in cancer patients particularly the extrinsic coagulation pathway is activated ${ }^{29,30}$. With the method used a higher APC-sr means a higher resistance to the anticoagulant action of APC and a lower APC-sr a lower resistance to APC, hence a more normal coagulation. Although APC-sr is significantly increased in breast cancer patients compared to healthy controls, we did not find that patients with metastases can be discriminated from patients without metastases by levels of APC-sr. However, after three years of follow-up there appeared to be a significantly increased APC-sr in surviving breast cancer patients compared to the patients not surviving (Chapter 8$)^{28}$. We hypothesize that for its growth and dissemination a tumor in an advanced stage is less dependent on a hypercoagulable state induced by acquired resistance to APC. This is in line with recent reports that all show that LMWH improves survival, but only in the patient groups with the relatively better prognosis ${ }^{1-3}$. Patients with advanced disease had little or no 
effect from LMWH treatment, also suggesting that these patients are less dependent on a hypercoagulable state. The fact that all patients with a low APC-sr and hence a more normal coagulation in the patient group with metastases did not survive the five year follow-up period supports this suggestion.

In our study increased plasma s-uPAR levels measured during follow-up in breast cancer patients with metastases did not discriminate between the patients surviving and the patients not surviving the three-year follow-up period $(\text { Chapter } 7)^{27}$. Also, plasma s-uPAR levels were not significantly correlated with disease free or overall survival. This is in contrast with previous observations of tumor levels of UPAR, that have been associated with a shorter disease free and overall survival, particularly in node-positive postmenopausal breast cancer patients ${ }^{31,32}$. We postulate that a single value of s-uPAR is of limited value in the follow-up breast cancer patients with and without metastatic disease.

We found significantly elevated factor XIla levels in breast cancer patients with metastases not surviving during the three-year follow-up period compared with those surviving ${ }^{27}$. The significant correlation with survival suggests a role of factor XIla in progression of disease. However, in patients with metastases the levels of factor XIla did not differ from the levels in patients without metastases. This limits the use of factor Xlla for the early detection of metastases during follow-up.

Plasma D-dimer levels were significantly elevated in the breast cancer patients with metastases compared to patients without metastases. More interestingly, D-dimer levels were increased more than threefold in the patients not surviving, compared to those surviving, and are therefore highly significantly correlated with survival ${ }^{27}$. Of the twelve patients with the highest D-dimer levels, none survived, including one patient in the patient group without metastases at the time of drawing the blood samples. The elevated D-dimer level could have been the first sign of metastatic disease. However, in this study the D-dimers could not predict metastatic disease in the patient group without metastases, probably due to the low number of patients developing metastases during the follow-up period. Of all the parameters we determined, the D-dimer was the most promising and accurate in predicting survival in the breast cancer patients.

We demonstrated that in breast cancer patients VWF levels are increased and discriminate between breast cancer patients with metastases, breast cancer patients without metastases and healthy controls (Chapter 8$)^{28}$. Moreover, the vWF level was significantly correlated with survival: the patients not surviving the three year follow-up period had a significantly higher vWF than the patients surviving. Of course, patients with metastases had a higher VWF and these patients already have a worse survival by the nature of their disease. However, 
the fact that the vWF levels in the patient group not surviving the three year follow-up period are higher than in the patient group with metastases and the fact that the significance between the groups after three years is increasing emphasizes that patients with the highest vWF levels have the worst survival. This is in line with results shown in colorectal cancer, where high vWF levels are associated with increased tumor stage, tumor invasion in adjacent organs and metastases ${ }^{33}$. We conclude that the VWF is promising as a prognostic marker in the follow-up of breast cancer patients.

\section{Haemostatic and fibrinolytic parameters as indicators of increased risk of venous thromboembolism}

We hypothesized that when a tumor cell is activating the haemostatic and fibrinolytic systems, because these systems are essential for its growth and dissemination, an increase or decrease of certain haemostatic or fibrinolytic factors might not only indicate the presence and activity of tumor cells, but may also be an indication of possible future venous thromboembolism. We prospectively followed the patients groups for more than five years to see whether elevated or decreased levels are associated with an increased incidence of venous thromboembolism. Indeed, three patients developed VTE during the follow-up period. All three had very high vWF and APC-sr levels ${ }^{28}$. All three patients were known with metastatic disease. Two of the three patients also had high s-uPAR and D-dimer levels. None of the other parameters showed any relevant difference. Although we understand that the number of patients that developed a VTE during the five year follow-up period is very low, we propose that high VWF and APC-sr levels are promising in predicting future VTE in breast cancer patients with metastatic disease. Whether this is an indication for prophylactic treatment with anticoagulants, e.g. with $\mathrm{LMWH}$, will be subject of further research. Recently it has been shown that LMWHs improve survival and reduce the risk of recurrent VTE in patients with cancer ${ }^{1-4}$. We hypothesize that particularly cancer patients with increased vWF levels are in a hypercoagulable state, have a decreased survival, are prone to venous thromboembolic disease and therefore could benefit from treatment with LMWH.

\section{Future perspectives}

Our studies were performed in a relatively small group of particularly welldefined breast cancer patients. Although not a single patient was lost to followup the results are hampered by the small groups of less than thirty patients per 
group. Although there were indeed very significant differences in certain variables, as s-uPAR and APC-sr, it was difficult to get significant differences in the two major outcome criteria during follow-up: the development of metastases in the patient group without metastases at the start of the study and the development of a VTE. The main reason for the small patient groups is the relatively small outpatient clinic of the Department of Oncology of the University Hospital Maastricht, where all patients treated for breast cancer were asked to participate and almost all, in fact, participated. Larger multicenter studies are needed to confirm the proof of the principle: a tumor cell is activating the haemostatic and fibrinolytic systems, essential for its growth and dissemination, and this activation therefore indicates the presence and activity of tumor cells and predicts future venous thromboembolism. Fortunately, large multicenter studies evaluating the effect of LMWH on survival in various tumors are currently being carried out. For example, a large international multicenter study is evaluating the effect of LMWH in cancer of the lung, pancreas or prostate. Patients are treated with the standard treatment according to their tumor stage with or without LMWH. Hopefully this study will give an answer to the primary question: is LMWH improving survival in cancer patients with advanced cancer of the lung, pancreas or prostate? In side studies many plasma factors will be measured to determine which patients have benefit of LMWH treatment and which patients do not. It can be hypothesized that patients with an increased D-dimer, vWF, s-uPAR and APC-sr have an activated state of the hemostatic and fibrinolytic system and profit by LMWH treatment. Another possibility is that plasma factors do not point specifically enough to those patients benefiting, and that other techniques, such as gene expression profiling by micro-arrays, are more accurate. When the effect of LMWH has been proven in patients with advanced disease, the next step will be adding LMWH to adjuvant treatment in cancer patients. The main goal of adjuvant treatment in breast or colorectal cancer, for example, is to prevent the development of local recurrence and distant metastases. Presently this is achieved with standard chemotherapy. Trials in breast cancer have shown that adding targeted therapy with monoclonal antibodies is improving disease-free survival in certain types of breast cancer $^{34,35}$. By adding this targeted immunotherapy to the standard therapy a substantial reduction in recurrences has been achieved. We hypothesize that, when it indeed has been proven that LMWH prolongs survival in advanced disease, LMWH treatment in the adjuvant setting added to the standard adjuvant treatment with chemotherapy and targeted therapy might give a further reduction in recurrences and distant metastases in breast cancer patients and other cancers. Let this thesis be a first step towards that goal. 


\section{References}

1. Klerk CP, Smorenburg SM, Otten HM, Lensing AW, Prins MH, Piovella F, Prandoni $P$, Bos MM, Richel DJ, van Tienhoven G, Buller HR. The effect of low molecular weight heparin on survival in patients with advanced malignancy. J Clin Oncol 2005;23:2130-5.

2. Lee AY, Rickles FR, Julian JA, Gent M, Baker RI, Bowden C, Kakkar AK, Prins M, Levine MN. Randomized comparison of low molecular weight heparin and coumarin derivatives on the survival of patients with cancer and venous thromboembolism. J Clin Oncol 2005;23:2123-9.

3. Kakkar AK, Levine MN, Kadziola Z, Lemoine NR, Low V, Patel HK, Rustin G, Thomas M, Quigley M, Williamson RCN. Low molecular weight heparin, therapy with dalteparin, and survival in advanced cancer: the Fragmin Advanced Malignancy Outcome Study (FAMOUS). J Clin Oncol 2004;22:1944-8.

4. Altinbas M, Coskun HS, Er O, Ozkan M, Eser B, Unal A, Cetin M, Soyuer S. A randomized clinical trial of combination chemotherapy with and without lowmolecular-weight-heparin in small cell lung cancer. $J$ Thromb Haemost 2004;2:1266-71.

5. Hutten BA, Prins MH, Gent M, Ginsberg J, Tijssen JG, Buller HR. Incidence of recurrent thromboembolic and bleeding complications among patients with venous thromboembolism in relation to both malignancy and achieved international normalized ratio: a retrospective analysis. J Clin Oncol. 2000;18:3078-83.

6. Ueno T, Toi M, Koike M, Nakamura S, Tominaga T. Tissue factor expression in breast cancer tissues: its correlation with prognosis and plasma concentration. $\mathrm{Br} \mathrm{J}$ Cancer 2000;83:164-70.

7. Sawada M, Miyake S, Ohdama S, Matsubara O, Masuda S, Yakumaru K, Yoshizawa $Y$. Expression of tissue factor in non-small-cell lung cancers and its relationship to metastasis. Br J Cancer 1999;79:472-7.

8. Shigemori C, Wada H, Matsumoto K, Shiku H, Nakamura S, Suzuki H. Tissue factor expression and metastatic potential of colorectal cancer. Thromb Haemost 1998;80:894-8.

9. Kakkar AK, Lemoine NR, Scully MF, Tebbutt S, Williamson SC.. Tissue factor expression correlates with histological grade in human pancreatic cancer. $\mathrm{Br} J$ Surg 1995;82:1101-4.

10. Maiola A, Tua A, Grignani G. Hemostasis and cancer: tumor cells induce the expression of tissue factor-like procoagulant activity on endothelial cells. Haematologica 2002;87:624-8.

11. Giavazzi R, Foppolo M, Dossi R et al. Rolling and adhesion of human tumor cells on vascular endothelium under physiological flow conditions. J Clin Invest 1993;92:3038-44.

12. Edwards RL, Rickles FR, Cronlund M. Abnormalities of blood coagulation in patients with cancer. Mononuclear cell tissue factor generation. J Lab Clin Med 1981;98:917-28.

13. Morgan D, Edwards RL, Rickles FR. Monocyte procoagulant activity as a peripheral marker of clotting activation in cancer patients. Haemostasis 1988;18:55-65.

14. Semeraro N, Montemurro $P$, Conese $M$, Giordano D, Stella M, Restaino A, Cagnazzo G, Colucci M. Procoagulant activity of mononuclear phagocytes from different anatomical sites in patients with gynaecological malignancies. Int $\mathrm{J}$ Cancer 1990;45:251-4. 
15. Nijziel MR, van Oerle R, van Pampus ECM, de Vet HCW, Hillen HFP, Hamulyák K. Increased D-dimer levels correlate with binding of activated protein $\mathrm{C}$, not tissue factor expression, on peripheral blood monocytes in cancer patients. Am J Hematol 2000;64:282-6.

16. Egorina EM, Sovershaev MA, Bjorkoy G, Gruber FX, Olsen JO, Parhami-Seren B, Mann KG, Osterud B. Intracellular and surface distribution of monocyte tissue factor: application to intersubject variability. Arterioscler Thromb Vasc Biol 2005;25:1493-8.

17. Sase T, Wada H, Kamikura Y, Kaneko T, Abe Y, Nishioka J, Nobori T, Shiku H. Tissue factor messenger RNA levels in leucocytes compared with tissue factor antigens in plasma from patients in hypercoagulable states caused by various diseases. Thromb Haemost 2004;92:132-9.

18. Nijziel MR, van Oerle $R$, van 't Veer $C$, van Pampus $E$, Lindhout $T$, Hamulyák $K$. Tissue factor activity in human monocytes is regulated by plasma: implications for the high and low responder phenomenon. Br J Haematol 2001;112:98-104.

19. Østerud B. The high responder phenomenon: enhancement of LPS induced tissue factor activity in monocytes by platelets and granulocytes. Platelets 1995;6:119-25.

20. Halvorsen H, Olsen JO, Østerud B. Granulocytes enhance LPS-induced tissue factor activity in monocytes via an interaction with platelets. J Leukoc Biol 1993;54:275-82.

21. Goad KE, Gralnick HR. Coagulation disorders in cancer. Hematol Oncol Clin North Am 1996;10(2):457-84.

22. Chou J, Mackman N, Merrill-Skoloff G, Pedersen B, Furie BC, Furie B. Haematopoietic cell-derived microparticle tissue factor contributes to fibrin formation during thrombus propagation. Blood 2004;104:3190-7.

23. Furie B, Furie BC. Cancer-associated thrombosis. Blood Cells Mol Dis 2006;36:177-81.

24. Mackman N. Role of tissue factor in hemostasis and thrombosis. Blood Cells Mol Dis 2006;36:104-7.

25. Furie B, Zwicker J, LaRocca T, Kos C, Bauer B, Furie BC. Tissue factor-bearing microparticles and cancer-associated thrombosis. Haematologica Reports 2005;1(9):5-8.

26. Nijziel MR, van Oerle R, Christella M, Thomassen LG, van Pampus EC, Hamulyak $\mathrm{K}$, Tans G, Rosing J. Acquired resistance to activated protein $\mathrm{C}$ in breast cancer patients. Br J Haematol. 2003;120:117-22.

27. Nijziel MR, van Oerle R, Hellenbrand D, van Pampus ECM, Hillen HFP, Hamulyák $\mathrm{K}$. The prognostic value of the soluble urokinase-type plasminogen activator receptor (s-uPAR) in plasma of breast cancer patients with and without metastatic disease. J Thromb Haemost 2003;1:982-6.

28. Nijziel MR, van Oerle R, Tans G, Rosing J, Hamulyák K. Increased von Willebrand Factor levels and acquired resistance to activated protein $C$ in breast cancer patients: implications after 3 and 5 years of follow-up. Submitted

29. Kakkar AK, DeRuvo N, Chinswangwatanakul V, Tebbutt S, Williamson RCN. Extrinsic-pathway activation in cancer with high factor VIla and tissue factor. Lancet 1995;346:1004-5.

30. Costantini V, De Monte P, Cazzato AO, Stabile AM, Deveglia R, Frezzato E, Paolucci MC. Systemic thrombin generation in cancer patients is correlated with extrinsic pathway activation. Blood Coagul Fibrinolysis 1998;9:79-84. 
31. Duggan C, Maguire T, McDermott E, O'Higgins N, Fennelly JJ, Duffy MJ. Urokinase plasminogen activator and urokinase plasminogen activator receptor in breast cancer. Int J Cancer 1995;61:597-600.

32. Grøndahl-Hansen J, Peters HA, van Putten WLJ, Look MP, Pappot H, Rønne E, Danø K, Klijn JGM, Brünner N, Foekens JA. Prognostic significance of the receptor for urokinase plasminogen activator in breast cancer. Clin Cancer Res 1995;1:1079-87.

33. Damin DC, Rosito M, Gus P, Roisemberg I, Bandinelli E, Schwartsmann G. Von Willebrand factor in colorectal cancer. Int J Colorectal Dis 2002;17:42-5.

34. Piccart-Gebhart MJ, Procter M, Leyland-Jones B, Goldhirsch A, Untch M, Smith I, Gianni L, Baselga J, Bell R, Jackisch C, Cameron D, Dowsett M, Barrios CH, Steger G, Huang CS, Andersson M, Inbar M, Lichinitser M, Lang I, Nitz U, Iwata H, Thomssen C, Lohrisch C, Suter TM, Ruschoff J, Suto T, Greatorex V, Ward C, Straehle C, McFadden E, Dolci MS, Gelber RD; Herceptin Adjuvant (HERA) Trial Study Team. Trastuzumab after adjuvant chemotherapy in HER2-positive breast cancer. N Engl J Med 2005;353:1659-72.

35. Romond EH, Perez EA, Bryant J, Suman VJ, Geyer CE Jr, Davidson NE, Tan-Chiu E, Martino S, Paik S, Kaufman PA, Swain SM, Pisansky TM, Fehrenbacher L, Kutteh LA, Vogel VG, Visscher DW, Yothers G, Jenkins RB, Brown AM, Dakhil SR, Mamounas EP, Lingle WL, Klein PM, Ingle JN, Wolmark N. Trastuzumab plus adjuvant chemotherapy for operable HER2-positive breast cancer. $\mathrm{N}$ Engl J Med. 2005;353:1673-84. 


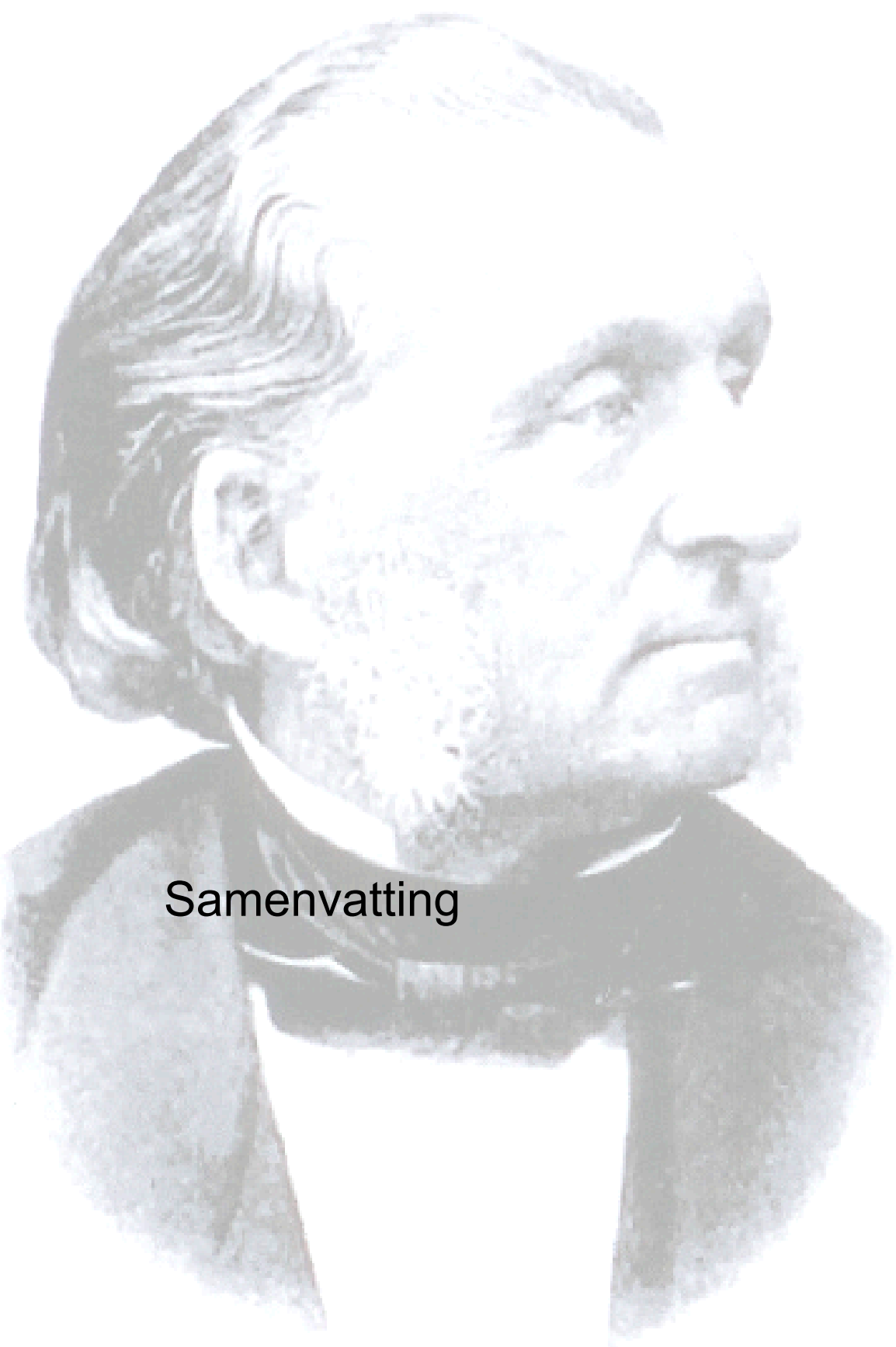




\section{Samenvatting}

\section{Het klinische probleem en de vraagstellingen}

In 1865 beschreef de Franse arts Armand Trousseau (1801-1867) voor het eerst de relatie tussen trombose en kanker. Het viel hem op dat trombosebenen en longembolieën meer voorkwamen bij patiënten met kanker en hij suggereerde een verandering in de samenstelling van het bloed van kankerpatiënten. Ook bijna 150 jaar later in 2006 is trombose een van de meest voorkomende complicaties van kanker. In 10-15\% van de patiënten met een bekende maligniteit worden diep veneuze tromboses of longembolieën, samen veneuze tromboembolieën (VTE), gezien. Deze treden spontaan op, of na operaties, tijdens chemotherapie of bij het gebruik van een centrale lijn. De kans op trombose is bij patiënten met kanker ongeveer zes keer zo groot in vergelijking met gezonden en in het geval van metastasen zelfs bijna twintig maal. Van alle patiënten die zich op de eerste hulp van een gemiddeld Nederlands ziekenhuis melden met een spontane VTE ontwikkelt 10-15\% binnen twee jaar een manifeste maligniteit. Het wordt steeds meer duidelijk dat dit geen toeval is. Een kankercel gebruikt de stolling namelijk om te groeien.

Tumorcellen kunnen op meerdere niveaus het stollingssysteem activeren, zowel in de primaire hemostase met de activatie van bloedplaatjes en de von Willebrand Factor als in de secundaire hemostase met de expressie van tissue factor leidend tot de vorming van fibrine. Dit fibrine vormt de matrix waarin tumorcellen nieuwe bloedvaatjes maken, de zogenaamde angiogenese. Via deze nieuwe vaatjes verzekert de tumor zich van de aanvoer van zuurstof en voedingsstoffen om te kunnen groeien. Bovendien kunnen de tumorcellen zich verspreiden via de gevormde bloedvaatjes en zo uitzaaien in het lichaam. Verschillende onderdelen van het stollingssysteem spelen een belangrijke rol bij de angiogenese, de groei en de metastasering van tumorcellen. De interactie tussen tumorcellen en het stollingssysteem leidt tot een verhoogde staat van activiteit van het stollingssysteem, hypercoagulabiliteit genoemd. Als afgeleide hiervan zien we in de klinische praktijk een toename van VTE bij kankerpatiënten. De recidiverende tromboflebitis die voorkomt bij kankerpatiënten wordt het syndroom van Trousseau genoemd, naar de eerste beschrijver ervan.

Ondanks het feit dat de relatie tussen stolling en kanker nu al bijna anderhalve eeuw bekend is, is er nog zeer veel onduidelijk. Hoe activeert de tumorcel de stolling nu precies? Is de stolling echt wel zo belangrijk of zijn er veel belangrijkere systemen waarvan de stolling slechts een ondergeschikt onderdeel vormt? Heeft het meten van stollingsactivatie bij een patiënt met een maligniteit klinische betekenis en is dit een aanwijzing dat er tumorcellen in het 
lichaam aanwezig zijn die de stolling activeren? Heeft stollingsactivatie bij patiënten met een maligniteit waarde in het voorspellen van toekomstige VTE? Heeft stollingsactivatie bij patiënten met een maligniteit voorspellende waarde voor wat betreft overleving? Op een deel van deze vragen probeert dit proefschrift antwoord te geven.

We hebben gekeken naar de mogelijke betekenis van een breed spectrum van stollingsfactoren bij kanker: factoren die rechtstreeks de stolling activeren (procoagulante factoren), factoren die de stolling remmen (anticoagulante factoren), factoren gerelateerd aan de fibrinolyse en factoren gerelateerd aan het endotheel.

\section{Procoagulante factoren: tissue factor activatie van monocyten nader bekeken}

Allereerst is gekeken naar factoren die rechtstreeks de stolling activeren, zogenaamde procoagulante factoren. De belangrijkste van deze factoren is het zogenaamde weefselfactor, tissue factor. Tissue factor (TF) is bij gezonden aanwezig in het subendotheel van de bloedvatwand. Bij een letsel van het bloedvat komt het subendotheliale tissue factor in aanraking met het bloed waarna verschillende stollingsfactoren in het bloed worden geactiveerd en uiteindelijk fibrinogeen omgezet wordt in fibrine. De gevormde fibrinedraden dichten mede het gat in de vaatwand. Bij patiënten met een maligniteit wordt een belangrijke rol in de stollingsactivatie toegedicht aan de aanwezigheid van TF op andere plaatsen dan in het subendotheel, zoals op tumorcellen zelf en op monocyten.

Er bestaat geen twijfel over de aanwezigheid van TF op kankercellen zelf. Wat betreft de aanwezigheid van TF op monocyten is er meer twijfel. De theorie is dat tumorcellen de monocyt kunnen aanzetten tot het maken van TF en dat deze TF op de celmembraan van de monocyt tot expressie wordt gebracht en zo de stolling kan activeren. Ook is bij niet-kankerpatiënten aangetoond dat monocyten van het ene individu bij stimulatie meer TF activiteit tonen dan monocyten van een ander individu bij dezelfde stimulatie. Dit wordt het hoogen laagresponder fenomeen genoemd. Dit fenomeen wordt toegeschreven aan het effect op de monocyt van granulocyten, trombocyten en LPS (lipopolysaccharide). Het zou hoog responders meer vatbaar maken voor coronaire hartziekten en trombose. Of dit fenomeen bij kankerpatiënten een rol speelt is nooit onderzocht.

TF op monocyten is bij kankerpatiënten aangetoond, maar vooral door middel van in vitro studies. Geïsoleerde monocyten van kankerpatiënten werden geactiveerd met LPS en lieten meer TF expressie zien dan monocyten van gezonden. Er zijn geen studies waarbij in vivo de TF expressie van monocyten is gemeten en vergeleken is met gezonde controles. Bovendien is stimulatie 
met LPS, een stof die vrijkomt bij ernstige infecties, te verdedigen in het geval van onderzoek naar TF expressie op monocyten bij bijvoorbeeld de diffuse intravasale stolling bij een meningococcensepsis, maar is deze niet (fysio)logisch bij patiënten met een maligniteit. Wij hebben twee belangrijke zaken onderzocht. Ten eerste hebben wij de TF expressie gemeten op monocyten direct in het perifere bloed. Ten tweede hebben wij onderzocht of het hoog- en laagresponder fenomeen bij kankerpatiënten aanwezig is en een rol kan spelen in de stollingsactivatie en de toegenomen kans op trombose bij deze patiënten.

Door direct met behulp van flowcytometrie bij patiënten met een gemetastaseerde maligniteit het aantal monocyten te meten dat TF tot expressie brengt werd door ons aangetoond dat slechts $10 \%$ van de monocyten van deze patiënten inderdaad TF op de celmembraan heeft ${ }^{1}$. Het is echter bekend dat van de totale hoeveelheid TF in de monocyt maar 10 tot 20 $\%$ tot expressie wordt gebracht op de celmembraan en dat 80 tot $90 \%$ in de monocyt zelf zit. Een manier om dit TF toch te meten is bepaling van het totale TF messenger RNA van de monocyt. Wij hebben er echter voor gekozen om de monocyten te lyseren (op te lossen). Op die manier kon met een nieuw ontwikkelde test de totale TF activiteit van de monocyt, zowel in de monocyt als aan de membraan gebonden, worden gemeten. Omdat bij kankerpatiënten LPS geen belangrijke rol speelt, hebben wij de TF activiteit van monocyten in deze test gemeten na stimulatie met plasma zonder LPS. Allereerst werd gekeken bij gezonden. Wij toonden aan dat in de afwezigheid van granulocyten, bloedplaatjes en LPS, plasma een belangrijke regulator is van de monocyten TF activiteit ${ }^{2}$. Twee sets monocyten, geïsoleerd van twee gezonde vrijwilligers, werden gestimuleerd met vele plasmamonsters, in de afwezigheid van granulocyten, bloedplaatjes en LPS, en reageerden identiek. Een plasmamonster dat in de ene set monocyten een hoge TF activiteit gaf deed dat ook in de andere set monocyten. Een plasmamonster dat in de ene set monocyten een lage TF activiteit gaf deed dat ook in de andere set monocyten. Hiermee werd het hoog- en laagresponder fenomeen bevestigd. Antistolling met coumarinederivaten had op het hoog- en laagresponder fenomeen geen effect $^{2}$.

Omdat bij patiënten met een maligniteit diverse veranderingen in plasma eiwitten zijn beschreven was de hypothese onzerzijds dat door deze veranderingen plasma van kankerpatiënten een hogere TF respons van monocyten zou geven dan plasma van gezonde controles. Dit zou een verklaring kunnen zijn voor de hypercoagulabiliteit van kankerpatiënten. Hoewel ook wij verschillen vonden in vele plasma eiwitten, passend bij activatie van de stolling en de fibrinolyse, kon de hypothese niet worden bevestigd. Wel 
was ook bij kankerpatiënten het hoog- en laagresponder fenomeen aanwezig, maar kankerpatiënten waren geen hogere responders dan gezonde controles ${ }^{3}$. Bovendien kon er geen correlatie worden aangetoond met activatie van de stolling.

Samenvattend laten onze studies bij herhaling zien dat bij patiënten met borstkanker en andere maligniteiten TF activiteit van monocyten niet gecorreleerd is met activatie van het stollingssysteem. Dit alles suggereert dat de stolling bij kankerpatiënten wordt geactiveerd door andere belangrijkere mechanismen dan TF activiteit van monocyten. Recent is gesuggereerd dat tissue factor dragende micropartikels, onder andere afkomstig van monocyten, een rol spelen bij de stollingsactivatie van kankerpatiënten. Deze micropartikels zijn te klein om met beide boven beschreven testen te worden opgemerkt. Daarom is het niet uit te sluiten dat er wel een rol is voor deze tissue factor dragende micropartikels afkomstig van monocyten.

\section{Anticoagulante factoren: resistentie tegen geactiveerd proteïne C}

De hypercoagulabiliteit bij kankerpatiënten wordt voornamelijk toegeschreven aan een toename van stollingsfactoren die de stolling activeren. De mogelijkheid dat een afname van factoren die normaal voor remming van de stolling zorgen, ook tot stolling kan leiden, heeft bij patiënten met een maligniteit tot nu toe niet of nauwelijks aandacht gekregen. Deze anticoagulante factoren zorgen er normaal voor dat de vorming van het fibrinestolsel beperkt blijft tot de plaats van de laesie in de vaatwand. Een van deze factoren is het geactiveerde proteïne $C$ (APC). APC remt samen met zijn co-factor proteïne $S$ de geactiveerde stollingsfactoren $V$ en VIII en daarmee de vorming van trombine en fibrine. Een deficiëntie van proteïne $C$ of een resistentie tegen APC zoals bij de factor $V$ Leiden leidt tot een verhoogde tromboseneiging. Onze hypothese was dat een resistentie tegen APC een rol zou kunnen spelen in de hypercoagulabiliteit bij kankerpatiënten. Wij hebben de APC resistentie bepaald met een eind jaren negentig in het laboratorium van de biochemie van de Universiteit Maastricht nieuw ontwikkelde test die het effect van APC meet op de trombinevorming geïnitieerd via TF. Omdat dit TF bij kankerpatiënten gezien wordt als belangrijkste activator van de stolling, leek deze test bij uitstek geschikt om bij kankerpatiënten resistentie tegen APC aan te tonen. Uiteraard werden patiënten met een factor $\mathrm{V}$ Leiden uitgesloten.

Inderdaad werd bij een grote groep vrouwen met borstkanker een significante resistentie tegen APC gevonden. Zowel vrouwen met borstkanker met metastasen als vrouwen zonder metastasen hadden een resistentie tegen APC. Opvallend was dat de correlatie met proteïne $S$ zoals die bij gezonden aanwezig is, proteïne $S$ is co-factor van APC, bij vrouwen met uitgezaaide 
borstkanker geheel verdwenen was ${ }^{4}$. Het mechanisme dat e.e.a. veroorzaakt is vooralsnog onduidelijk. Ons onderzoek is het allereerste geweest bij vrouwen met borstkanker en tevens het eerste bij kankerpatiënten met deze nieuwe test.

Samenvattend zou een verworven APC-resistentie een rol kunnen spelen bij de hypercoagulabiliteit van kankerpatiënten.

\section{Factoren uit de fibrinolyse: de oplosbare urokinase-type plasminogeen activator receptor}

In de normale fibrinolyse wordt plasminogeen omgezet in plasmine na activatie door tPA (tissue plasminogeen activator) of uPA (urokinase-type plasminogeen activator). Dit plasmine breekt het gevormde fibrinestolsel af tot de fibrine afbraakproducten fragment $D$, fragment $E$ en D-dimeren. Plasmine wordt geïnactiveerd door alpha2-antiplasmine door de vorming van plasmine-alpha2antiplasmine (PAP) complexen. Bij kankerpatiënten lijkt in het bijzonder het urokinase-type plasminogeen activator systeem een rol te spelen. Hierbij bindt UPA aan de UPA receptor (UPAR), die onder andere aanwezig is op monocyten en op tumorcellen. Daardoor wordt plasminogeen omgezet in plasmine. Plasmine is een protease dat niet alleen in staat is om fibrine te splitsen, maar ook direct, of indirect via zogenaamde matrix metalloproteinases, de extracellulaire matrix afbreekt. Daardoor kunnen tumorcellen en monocyten ter plaatse de matrix binnendringen en zich verspreiden. De oplosbare urokinasetype plasminogeen activator receptor (s-uPAR) reflecteert de lokale expressie en uitscheiding van UPAR en kan dus een maat zijn voor de activiteit van uPAR op tumorcellen en/of monocyten. PAP complexen zijn een goede weergave van de plasminevorming, D-dimeren een maat voor de afbraak van fibrine en stollingsfactor $\mathrm{XII}$ is een bekende plasminogeen activator.

De s-uPAR was significant hoger in borstkankerpatiënten met metastasen in vergelijking met borstkankerpatiënten zonder metastasen en gezonde controles ${ }^{5}$. Er was geen verschil tussen de patiënten zonder metastasen en de controles. Ook de PAP-complexen en de D-dimeren waren significant verhoogd bij de borstkankerpatiënten met metastasen in vergelijking met de patiënten zonder metastasen en gezonde controles. Er was geen verschil in UPA of stollingsfactor XII tussen de groepen. Deze resultaten suggereren een lokale activiteit en uitscheiding van UPAR zonder toename van UPA in het plasma. Meest logische verklaring is dat lokaal uPA van tumorcellen of monocyten bindt aan de UPAR en daardoor plasminogeen wordt omgezet in plasmine. Ook de sterke toename in PAP-complexen en D-dimeren past hierbij. 
Samenvattend lijkt activering van het fibrinolytisch systeem en met name het urokinase-type plasminogeen activator systeem een belangrijke rol te spelen bij onze borstkankerpatiënten.

\section{Factoren gerelateerd aan het endotheel: de von Willebrand Factor}

Bij patiënten met een maligniteit wordt interactie van de tumorcel met het endotheel gezien als een van de mechanismen die bijdragen aan de verhoogde stollingsneiging. In het endotheel worden vele belangrijke eiwitten gesynthetiseerd, onder andere eiwitten die een rol spelen in de stolling zoals de von Willebrand Factor (VWF). De vWF is het dragereiwit voor stollingsfactor VIII en bevordert in de primaire hemostase de adhesie van bloedplaatjes aan de vaatwand waardoor een letsel in de vaatwand wordt gedicht door een bloedplaatjesprop. Bij kankerpatiënten zijn verhoogde waardes van de vWF beschreven. Dit wordt toegeschreven aan endotheelschade door tumorcellen met vrijkomen van vWF, endotheelactivatie door tumorcellen met vrijkomen van vWF en aan de angiogenese door tumorcellen zelf. Er zijn aanwijzingen dat VWF de binding van tumorcellen aan bloedplaatjes bevordert waardoor de tumorcellen zijn omgeven door bloedplaatjes en zich kunnen onttrekken aan het immuunsysteem.

Inderdaad was de vWF significant verhoogd bij borstkankerpatiënten met metastasen in vergelijking met borstkankerpatiënten zonder metastasen en gezonde controles. De borstkankerpatiënten zonder metastasen hadden op hun beurt een significant hogere VWF dan gezonde controles ${ }^{6}$. Eerder was al bij dikke darmkanker aangetoond dat de vWF geassocieerd was met het stadium van de tumor en de aanwezigheid van metastasen. Ons onderzoek is het eerste dat dit nu ook bij borstkanker heeft aangetoond.

\section{Parameters uit het stollingssysteem als maat voor tumor activiteit: voorspellende waarde voor overleving, metastasering of VTE?}

Onze hypothese was dat als een tumorcel het stollingssysteem en de fibrinolyse activeert omdat deze systemen essentieel zijn voor groei en metastasering van de tumor, een toename of afname van bepaalde factoren uit de stolling of fibrinolyse een aanwijzing zou kunnen zijn dat er levende tumorcellen in het lichaam aanwezig zijn. De geactiveerde stolling zou prognostische betekenis kunnen hebben primair voor het optreden van metastasen en secundair voor de overleving bij al gemetastaseerde patiënten. Bovendien zou de stollingsactivatie een rol kunnen spelen in het krijgen van een VTE. Routine stollingstesten als de APTT en de PT verschillen bij kankerpatiënten niet van gezonden. Daarom hebben wij gekeken naar andere parameters, die meer op detailniveau een rol spelen in stolling of fibrinolyse, zoals trombinegeneratie, APC resistentie, de s-uPAR, PAP-complexen, 
stollingsfactor XII, D-dimeren en de vWF. Van al deze parameters werden significant verhoogde waardes gevonden bij patiënten met borstkanker ${ }^{4-6}$. Alle patiënten uit ons onderzoek werden gedurende vijf jaar vervolgd. Ondanks dat interpretatie van de resultaten bemoeilijkt wordt door de relatief kleine patiëntengroepen zijn er toch opvallende bevindingen.

APC-resistentie. Hoewel de APC-sr bij patiënten met borstkanker significant verhoogd is, wijzende op een verworven APC-resistentie, kon de APC-sr niet discrimineren tussen patiënten met en zonder metastasen. Wel was zeer opvallend dat de APC-sr significant hoger was bij patiënten die na drie jaar follow-up nog in leven waren in vergelijking met de in die tijd overleden patiënten. Dit suggereert dat patiënten met een verdergevorderd stadium van ziekte minder afhankelijk zijn van de stollingsactivatie zoals die veroorzaakt wordt door een APC-resistentie. De APC-sr was niet significant verschillend bij de zes patiënten die gedurende de vijf jaar follow-up metastasen ontwikkelden. Hoewel in de follow-up slechts drie patiënten een VTE kregen hadden alle drie sterk verhoogde APC-sr waardes. Dit suggereert een mogelijke rol van APCresistentie bij het ontwikkelen van een $\mathrm{VTE}^{6}$.

$s-u P A R$. Een eenmalige meting van de s-uPAR in de follow-up bij borstkankerpatiënten met en zonder metastasen had geen voorspellende waarde voor overleving, het krijgen van metastasen of VTE ${ }^{5}$. Dit dus ondanks het feit dat de s-uPAR significant verhoogd was bij borstkankerpatiënten met metastasen in vergelijking met patiënten zonder metastasen en controles.

Stollingsfactor XII: factor XII was significant verhoogd bij de borstkankerpatiënten met metastasen die na drie jaar follow-up overleden waren. Dit suggereert een rol van factor XII bij progressie van de ziekte. Echter, het ontbreken van een significant verschil tussen patiënten met metastasen, patiënten zonder metastasen en gezonde controles, maakt de waarde van factor XII in de follow-up beperkt. Ook had factor XII geen voorspellende waarde voor het krijgen van metastasen of een VTE ${ }^{5}$.

D-dimeer: Hoe hoger de D-dimeer waarde, des te slechter de overleving. De Ddimeer waardes waren meer dan drie maal zo hoog bij de patiënten die na drie jaar follow-up overleden waren en zijn daardoor sterk gecorreleerd met de overleving. De twaalf patiënten met de hoogste D-dimeer waardes zijn gedurende de follow-up allen overleden. Bij een patiënte zonder metastasen was de D-dimeer waarde sterk verhoogd. Zij ontwikkelde levermetastasen en overleed na 30 maanden follow-up. De sterk verhoogde D-dimeer waarde zou het eerste teken kunnen zijn geweest van de metastasering. Bij de patiënten die een VTE ontwikkelden gedurende de follow-up had de D-dimeer geen voorspellende waarde, hoewel twee van de drie patiënten hoge D-dimeer waardes hadden ${ }^{5}$. 
VWF: Hoe hoger de VWF waarde, des te slechter de overleving. De vWF had geen voorspellende waarde voor het krijgen van metastasen gedurende de follow-up. Wel hadden de drie patiënten die een VTE ontwikkelden allen een sterk verhoogde vWF waarde ${ }^{6}$. Hoewel als gezegd de patiëntengroepen relatief klein waren en het aantal patiënten dat een VTE ontwikkelde ook, zou dit kunnen betekenen dat een hoge VWF bijdraagt aan het krijgen van een VTE en een teken is van hypercoagulabiliteit.

Samengevat lijken met name de D-dimeer en vWF waarde veelbelovend voor het voorspellen van de overleving bij borstkankerpatiënten. Bovendien zijn de vWF en de APC-sr mogelijk van voorspellende waarde voor het krijgen van een VTE.

Recent is aangetoond dat laag moleculair gewicht heparine (LMWH) mogelijk levensverlengend kan werken bij patiënten met een gemetastaseerde maligniteit ook zonder een klinisch manifeste VTE. Onze studies suggereren dat kankerpatiënten met een hoge D-dimeer, vWF, s-uPAR en APC-sr een geactiveerde stolling en fibrinolyse hebben. Onze hypothese is dat juist deze patiënten baat hebben bij een behandeling met LMWH. Langzamerhand beginnen we meer te begrijpen van de hypercoagulabiliteit bij kankerpatiënten, waardoor nieuwe mogelijkheden worden geopend voor de behandeling van trombose bij kanker maar ook voor de behandeling van de onderliggende maligniteit. Meer inzicht in de onderliggende mechanismen kan in de toekomst leiden tot de ontwikkeling van nieuwe middelen die ingrijpen in de biologie van de tumor. Wij hopen dat dit proefschrift hier een kleine bijdrage aan geleverd heeft. 


\section{References}

1. Nijziel MR, van Oerle R, van Pampus ECM, de Vet HCW, Hillen HFP, Hamulyák K. Increased D-dimer levels correlate with binding of activated protein $\mathrm{C}$, not tissue factor expression, on peripheral blood monocytes in cancer patients. Am J Hematol 2000;64:282-6.

2. Nijziel MR, van Oerle R, van 't Veer C, van Pampus E, Lindhout T, Hamulyák K. Tissue factor activity in human monocytes is regulated by plasma: implications for the high and low responder phenomenon. Br J Haematol 2001;112:98-104.

3. Nijziel MR, van Oerle R, van Pampus ECM, Hillen HFP, Hamulyák K. Tissue factor activity in monocytes of cancer patients: evidence for the high and low responder phenomenon. Thesis: Chapter 5. Submitted.

4. Nijziel MR, van Oerle R, Christella M, Thomassen LG, van Pampus EC, Hamulyak $\mathrm{K}$, Tans G, Rosing J. Acquired resistance to activated protein $\mathrm{C}$ in breast cancer patients. Br J Haematol. 2003;120:117-22.

5. Nijziel MR, van Oerle R, Hellenbrand D, van Pampus ECM, Hillen HFP, Hamulyák $\mathrm{K}$. The prognostic value of the soluble urokinase-type plasminogen activator receptor (s-uPAR) in plasma of breast cancer patients with and without metastatic disease. J Thromb Haemost 2003;1:982-6.

6. Nijziel MR, van Oerle R, Tans G, Rosing J, Hamulyák K. Increased von Willebrand Factor levels and acquired resistance to activated protein $C$ in breast cancer patients: implications after 3 and 5 years of follow-up. Thesis: Chapter 8. Submitted. 


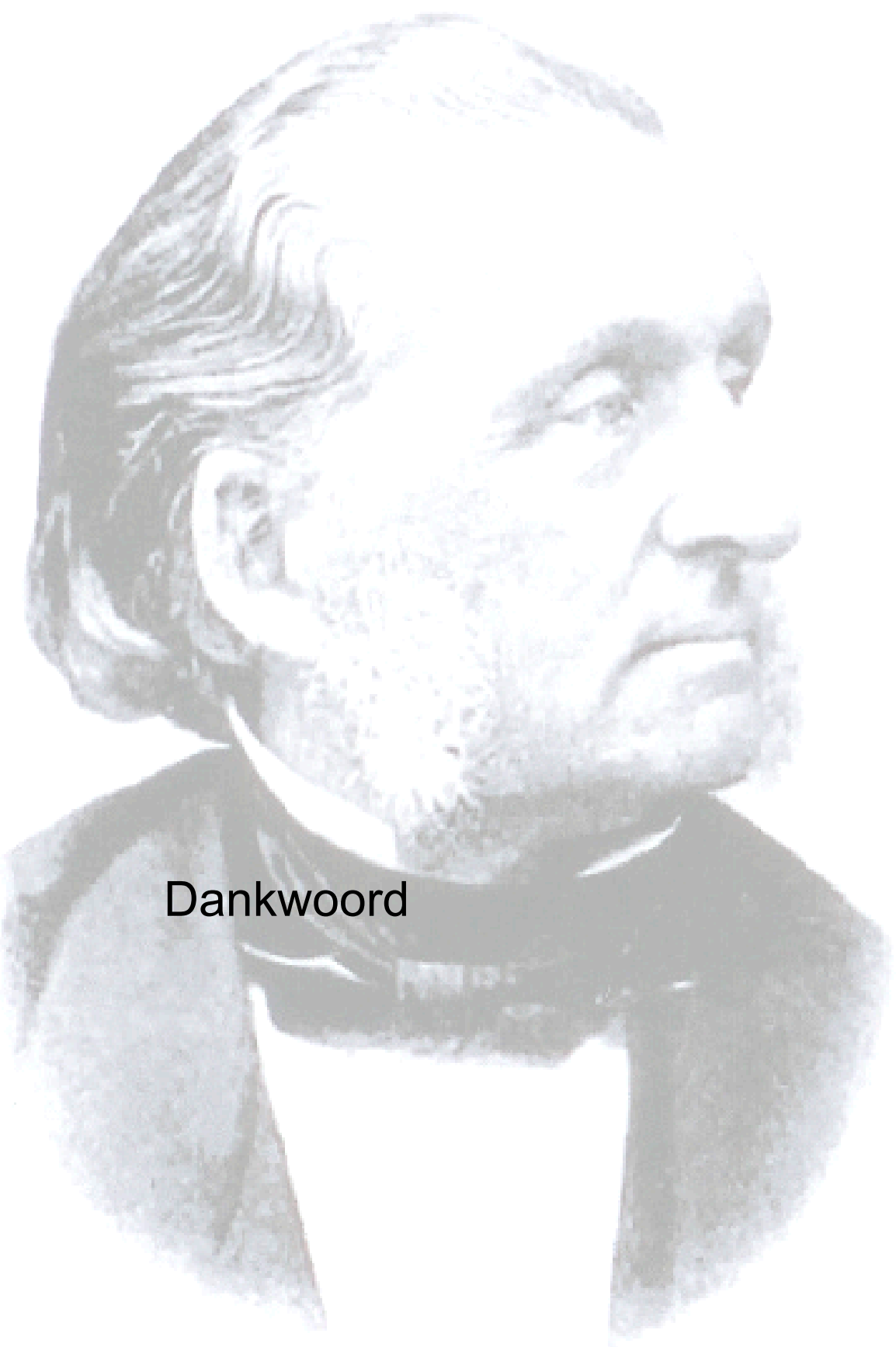




\section{Dankwoord}

Het dankwoord is het meest gelezen onderdeel van een proefschrift. Ik zou van de gelegenheid gebruik kunnen maken om u nog eens de boodschap van dit proefschrift mee te geven, ervan uitgaande dat de meerderheid van u de rest van het proefschrift in het geheel niet gelezen heeft. U kunt ook gewoon alsnog de Nederlandse samenvatting lezen.

Dit proefschrift is op vele plaatsen geschreven. Natuurlijk tijdens de vijf jaren dat ik werkzaam was in het academisch ziekenhuis Maastricht (azM) op de raamloze inpandige kamer van René op het laboratorium. Grote delen zijn ook geschreven thuis in Eindhoven op zolder en tijdens de loze uurtjes van congressen in San Diego, Orlando, Scottsdale, Berlijn, Bangkok en Vancouver. Een grote stap voorwaarts werd gemaakt in het voorjaar van 2005 door een week in afzondering op ons vertrouwde adres in El Castillo op Fuerteventura te gaan zitten, resultaten te analyseren en twee hoofdstukken te schrijven. Een en ander heeft uiteindelijk geleid tot dit proefschrift en vele presentaties over dit onderwerp in binnen- en buitenland. Ook ik begin als eenoog Koning in het Land der Blinden te worden. Ik zal echter blijven proberen mijn opgedane kennis van de afgelopen jaren door te geven aan anderen. Terdege realiseer ik me dat dit alles het resultaat is van het werk, het doorzettingsvermogen, de ideeën en het opofferingsgezindheid van vele anderen. En daar begint dit dankwoord.

Allereerst mijn promotor professor Hillen. Beste Harry, onze eerste kennismaking was in september 1993. Ik kwam op sollicitatiegesprek voor een assistentenplaats in het Catharina Ziekenhuis in Eindhoven. Het gesprek vond plaats op de polikliniek op de $2^{\mathrm{e}}$ etage waar op jouw kamer ook Wim Breed bij het gesprek aanwezig was. Na ongeveer 30 seconden ging jouw pieper af en werd het gesprek voortgezet door Wim die op zijn eigen sympathieke wijze het gesprek gaande hield tot ongeveer 20 minuten later jij de telefoon weer neerlegde en voor mij het oordeel uitsprak: "ik denk dat we het wel weten, $u$ hoort van ons" en ik weer buitenstond. Je hebt het blijkbaar altijd geweten. Toen ik weer thuis was in Utrecht stond je op mijn antwoordapparaat. Ik was aangenomen en mocht twee weken later beginnen. Later bleek dat er geen andere kandidaat was. Ik mocht ook nog op 5 west als assistent bij jou beginnen en zette zo mijn eerste stappen in de hemato-oncologie. Na drie maanden vertrok je naar Maastricht om hooggeleerd te worden en scheidden helaas onze wegen. Vier jaar later haalde je me vervroegd naar het azM om onderzoek te doen naar de klinische toepasbaarheid van de trombinepotentiaal. Al na enige weken echter werd onze interesse verlegd naar de intrigerende relatie tussen de stolling en kanker, hetgeen meer paste bij 
mijn wens om hemato-oncoloog te worden. Ik heb als internist en mens veel van je geleerd. Je bent een eminente clinicus en persoonlijk vind ik het spijtig dat je de laatste jaren zo weinig klinisch werkzaam bent geweest. Ook ben je een groot spreker, die zijn publiek geboeid weet te houden tot en met de laatste zin van het verhaal. Ik vind het een grote eer de cirkel rond te maken en bij je te promoveren. Voor alles ben ik je zeer veel dank verschuldigd.

Vervolgens mijn copromotor dr. Hamulyák. Beste Karly, jouw kennis van de stolling is uitmuntend en de basis geweest van de ideeën die hebben geleid tot dit proefschrift. De vele uren die we op jouw kamer op het Laboratorium Hematologie hebben doorgebracht zijn niet voor niets geweest. Jij hebt mij een zodanige kennis van de hemostase bijgebracht dat ik daar dagelijks profijt van heb. Ik bewonder jouw rust, kalmte en geduld. In de afgelopen negen jaar heb jij mij regelmatig moeten aansporen vaart te maken met het onderzoek. Nooit ging dat op een onplezierige wijze. Jij bent de man die met zijn contacten in stollingsland ervoor zorgde dat ik eerst op kleine bijeenkomsten en later op grote congressen mijn resultaten mocht tonen en zelfs sessies mocht voorzitten. Ik ben je voor alles veel dank verschuldigd en vind het een voorrecht dat je mijn copromotor bent.

Als derde René van Oerle. Beste René, eigenlijk zou jij als eerste genoemd moeten worden. Zonder jou zou dit proefschrift en een groot deel van de resultaten er nooit gekomen zijn. Jij hebt als analist een groot deel van het handwerk gedaan. Op mijn allereerste dag in het azM bleek mijn bureau naast het jouwe te staan in een kamer die in de meeste studentenhuizen vanwege de grootte en het gebrek aan ramen onverhuurbaar zou zijn. Diezelfde dag vertelde je me dat de onderzoekslijn waarop ik promotieonderzoek zou komen doen, was vastgelopen en dat het niet zinnig was om daarmee door te gaan. Je had nog wat monocytenwerk liggen waarbij je wat geëxperimenteerd had met gezuiverde monocyten. Al brainstormend zijn we vervolgens met monocyten aan de slag gegaan en vanwege mijn oncologische belangstelling zijn we gaan kijken bij kankerpatiënten. Al gauw vonden we opmerkelijke verschillen met gezonde controles. De namen Kerkoerle en Morreau zijn in die tijd voor ons beide een begrip geworden. Vervolgens zijn we grotere hoeveelheden plasma gaan verzamelen van zowel kankerpatiënten als gezonden. Een deel van het meetwerk heb jij in je eentje gedaan toen ik al weer klinisch werkzaam was op A5 links en op de polikliniek om mijn opleiding af te maken. Toen jij 25 jaar in dienst was bij het azM noemde je mij in je dankwoord en zei dat je bewondering had voor het feit dat we op een heel dun randje waren begonnen en dat er nu een stevig fundament was gekomen. Dat fundament is voor het grootste deel aan jou te danken. Ik ben blij dat met de komst van Hugo ten Cate jouw functie van nog grotere waarde is geworden en 
dat zoals het er nu naar uitziet de onderzoekslijn naar kanker en stolling voortgezet zal worden. Als uiting van mijn grote dank heb ik je gevraagd mijn paranimf te worden en ik ben verheugd dat je dat wilt zijn.

Dan Tiny Wouters. Beste Tiny, voorheen had ik geen idee wat je allemaal uitspookte in dat kleine hok van je op de gang van de Interne Geneeskunde op de $5^{\mathrm{e}}$ etage van het azM. Van andere promovendi hoorde ik dat je onmisbaar bent in de laatste fase van een proefschrift. Dat je zó belangrijk bent in deze fase had ik niet kunnen vermoeden. Jouw ervaring en inzicht bij het drukklaar maken van het manuscript zijn onmisbaar. Jij hebt ervoor gezorgd dat het manuscript in ordentelijke staat bij de beoordelingscommissie kwam. Jij hebt ervoor gezorgd dat de drukker direct zijn gang kon gaan. Ondanks alle kleine wijzigingen in de laatste dagen voor de allerlaatste definitieve versie voor de drukker, heb je nooit je geduld verloren. Als ik 's avonds tegen twaalven weer een nieuwe versie op de mail deed, kreeg ik die om kwart over twaalf weer aangepast retour. Ik realiseer me dat we de laatste spelfout en inconsequentie nooit uit de stukken zullen halen, hoe zeer we dat ook geprobeerd hebben. Zoals jij zei "alles wat we er nu nog uithalen is meegenomen". Het is meer dan meegenomen dat de vakgroep Interne Geneeskunde van het azM jou heeft vrijgemaakt om onze proefschriften te voltooien. Hulde en zeer veel dank.

Vervolgens zijn onmisbaar geweest de leden van de beoordelingscommissie: professor ten Cate, professor Levi, professor Prins, professor Rosing en professor Schouten.

Professor ten Cate, beste Hugo, jouw komst naar Maastricht is voor het klinische en fundamentele onderzoek van de hemostase het beste dat de vakgroep kon overkomen. Het enthousiasme dat een ieder weer heeft om de geheimen van de hemostase en trombose verder te ontrafelen is door jou geïnitieerd. Het is prachtig dat de onderzoekslijn naar de relatie tussen stolling en kanker in samenwerking met onze collega's uit Bergamo gaat worden voortgezet. Ik vind het een eer dat je voorzitter van de beoordelingscommissie bent.

Professor Levi, beste Marcel, wij kennen elkaar al vanaf onze assistententijd in de jaren negentig toen we samen in het JNIV bestuur zaten. Al vroeg was je expert op het gebied van de trombose en hemostase en een voortreffelijke spreker op nationale en internationale congressen. Ondanks het feit dat je al op jonge leeftijd hooggeleerd werd, ben je altijd jezelf gebleven. Ik heb hier grote bewondering voor. Toen ik je op de laatste Internistendagen in Maastricht vroeg om zitting te nemen in de beoordelingscommissie van mijn proefschrift was je vereerd. Die eer is wederzijds.

Professor Prins, beste Martin, ook jouw komst vanuit Amsterdam is van groot belang geweest voor het onderzoek in Maastricht. Eigenlijk heb ik voor mijn 
proefschrift te weinig gebruik gemaakt van jouw expertise. Aangezien de stolling bij kankerpatiënten ook jouw specifieke aandacht heeft, komen we elkaar meerdere malen per jaar tegen als het selecte gezelschap dat zich in de wereld hiermee bezighoudt bij elkaar komt. Als ik het in mijn zevende stelling heb over eenoog als Koning in het Land der Blinden, die probeert te voorkomen dat het Land der Blinden een republiek wordt, is dat zeker niet op jou van toepassing. Jij bent juist het voorbeeld van iemand die probeert zijn kennis op het gebied van kanker en stolling te delen. Ik ben er trots op dat ook jij in de beoordelingscommissie zit.

Professor Rosing, beste Jan, als biochemicus lijk je een vreemde eend in de bijt tussen de anderen in de beoordelingscommissie. Niets is minder waar. Als wetenschapper heb je altijd oog gehad voor de klinische relevantie van het onderzoek van je afdeling. Meest bekende voorbeeld daarvan is de APCresistentie die je aantoonde bij pilgebruiksters. Toen René en ik bij je aanklopten om jouw test ook te gebruiken bij patiënten met borstkanker, was je onmiddellijk enthousiast; toen we de verworven APC-resistentie bij onze kankerpatiënten aantoonden nog enthousiaster. Ik ben zeer verheugd dat je in de beoordelingscommissie hebt willen plaatsnemen.

Professor Schouten, beste Harry, toen ik in 1997 naar het azM kwam om mijn opleiding voort te zetten vroeg jij mij in het sollicitatiegesprek waarom ik in hemelsnaam oncoloog wilde worden. De hematologie was toch veel interessanter en in jouw ogen moest ik maar hematoloog worden. Ik wilde graag beide aandachtsgebieden volgen en ben begonnen met de hematologie. Ik was de eerste assistent in jaren die het aandachtsgebied ging volgen en weet dat je erg teleurgesteld was toen ik niet solliciteerde op een van de twee vacatures voor hematologen bij de vakgroep in 2002. Ik blijf van mening dat het niet goed is om aan de slag te gaan in de groep waarin je bent opgeleid. Uiteindelijk ben ik vijf jaar werkzaam geweest bij de vakgroep, met in de dagelijkse praktijk opleiding in zowel de hematologie als de oncologie. De officiële opleiding in het aandachtsgebied oncologie heb ik nooit meer gedaan. In oktober 2002 kreeg ik de kans aan de slag te gaan in het Máxima Medisch Centrum in Eindhoven/Veldhoven, waar ik de hematologie en de oncologie in de volle breedte kan bedrijven. Ik vind het een eer dat jij mijn opleider bent geweest in het aandachtsgebied hematologie en ben blij dat je in de beoordelingscommissie zitting hebt willen nemen.

Het onderzoek had niet kunnen worden uitgevoerd zonder de bereidwillige medewerking van de overige leden van de vakgroep hematologie-oncologie, die aan hun patiënten op de polikliniek moesten vragen extra bloed af te staan. Daarvoor wil ik graag John Wagstaff, Rob Jansen, Pierre Hupperets, Roy Lalisang en Annemarie ten Haaft bedanken. Een speciaal woord van dank aan Lizzy van Pampus. Beste Lizzy, jij bent vanaf het begin bij een groot deel van 
de onderzoeken betrokken geweest. Telkens weer kwam je met nieuwe ideeën en artikelen waarvan René en ik pas een half jaar later begrepen dat je drie stappen verder was dan wij. Het idee de fibrinolyse te bekijken met speciale aandacht voor uPA en de uPAR kwam van jou. Jij zat al in de matrix metalloproteinases voordat wij überhaupt wisten dat er een relatie met ons onderzoek kon zijn. Ik heb bewondering voor je kennis en het enthousiasme waarmee je het vak bedrijt. De patiënten lopen met je weg, maar pas goed op jezelf. Ook Gerard Bos en Michel van Gelder wil ik danken voor hun luisterend oor als ik eens stoom wilde afblazen gedurende mijn tijd in het azM. De discussies met jullie over de vakgroep, het onderzoek en de hematologie hebben mij een betere hematoloog gemaakt.

Vele medewerkers van het Laboratorium Hematologie hebben meegeholpen met het verzamelen en verwerken van alle monsters, waarvoor mijn dank. Een speciaal woord van dank gaat uit naar Carol, Carina en Dave van de speciële stolling voor alle hulp en gezelschap gedurende mijn vijf jaar in het azM. Bert, Anny, Tiny en Gerdie van de speciële hematologie hebben mij geduldig de beginselen bijgebracht van de flowcytometrie zodat ik zelf kon meten. Daarvoor en voor hun gezelschap wil ik hen bedanken. Henk, die ooit René heeft gered van een acute leukemie en (samen met Pieter en Dirk van Paassen) de enige echte Feyenoord supporter in Limburg is, zorgde ervoor dat alle monsters inderdaad door zijn mensen adequaat werden verwerkt. Theo Lindhout, Cees van 't Veer en Guido Tans wil ik danken voor hun niet onaanzienlijke bijdrage aan ons denk- en schrijfwerk. Als laatste van mijn Maastrichtse tijd wil ik iedereen danken die ik hier niet bij naam genoemd heb zoals bij voorbeeld arts-assistenten, poli-assistentes, verpleegkundigen en studentstagiaires die allen een kleinere of grotere bijdrage aan het onderzoek geleverd hebben.

In de vier jaren die ik nu in Eindhoven werkzaam ben, hebben de data van het onderzoek moeten rijpen. Tijdens de sollicitatieprocedure meldde ik dat het proefschrift in een afrondende fase was. Dat was ook zo omdat we streefden naar drie jaar follow-up. Het blijkt toch moeilijker dan gedacht om met de overname van een drukke praktijk, een jong opgroeiend gezin en een terecht veeleisende echtgenote tijd vrij te maken om eens in alle rust data te analyseren en te schrijven. En zo werd drie jaar follow-up vanzelf de in de oncologie gebruikelijke vijf jaar follow-up. Ik ben mijn maten dankbaar dat ze me de tijd gegund hebben het proefschrift rustig af te maken. Harm Haak, Louis Lieverse, Wouter Dercksen, Brian Blank, Hans van Wijk, Cees van Es, Jan Kamphuis en Paul Boekema wil ik daarvoor danken. Een speciaal woord van dank voor Wouter. Samen hebben we, met steun van vele anderen zonder wie het nooit gelukt was, de afgelopen vier jaren de afdeling hematologie en oncologie opgebouwd. Het streven was te komen tot volledige integratie van de poliklinische zorg, polikliniek en dagbehandeling, voor de patiënt met een 
hematologische of oncologische ziekte. Met de opening van ons Hematologisch Oncologisch Centrum op de hele $3^{\mathrm{e}}$ etage van ons ziekenhuis is deze wens in vervulling gegaan. Samen zullen we deze afdeling, als de politiek het ons toestaat, verder uitbouwen. Ik zie in ons een koppel zoals ooit Wim Breed en Harry Hillen dat waren in mijn opleidingstijd in het Catharina Ziekenhuis: zeer verschillende karakters, maar complementair en een hecht team. Dank voor al die uren dat je voor mij hebt waargenomen als ik weer eens aan het vergaderen was of afwezig was vanwege mijn proefschrift.

Er zijn nog andere "Eindhovenaren" die ik apart wil bedanken. Allereerst Steven Hoorntje. Beste Steven, jij was mijn opleider in het Catharina Ziekenhuis toen Harry Hillen je benaderde om mij een jaar eerder af te staan aan het azM om dit promotieonderzoek te gaan doen. Hoewel het een mooie manier was om eerder van mij af te komen, heb je mij afgeraden alleen "stolloloog" te worden zoals je het noemde. Dat is mede de reden geweest dat ik niet voor een academische carrière heb gekozen en terug ben in Eindhoven om het vak in de volle breedte uit te oefenen, zoals jij het ons voordeed. Daarvoor en voor alle wijze lessen wil ik je danken. Vervolgens Wim Peters. Beste Wim, als opvolger van Harry Hillen gedurende de eerste maanden van mijn opleidingstijd, heb ook jij mij wegwijs gemaakt in de hematologie. Ik zie je nog staan met zweetdruppels op je voorhoofd op je eerste dag tijdens een beenmergpunctie bij een patiënt met een acute promyelocyten leukemie. $\mathrm{Er}$ zijn eenvoudiger manieren om aan een nieuwe baan te beginnen. Jij was de eerste die aangaf aan dat ik internist moest worden. Ik heb door jou het vak leren relativeren. Samen weten we dat de natuur mild kan zijn. Voor alle wijze woorden wil ik je danken. Tenslotte Wim Breed. Beste Wim, gedurende de twee jaar dat jij mijn opleider was is de basis gelegd voor een blijvend contact ook na jouw pensionering. Je bent voor mij altijd het voorbeeld geweest hoe een oncoloog dient te zijn: consciëntieus, zeer precies, altijd beheerst en met een luisterend oor voor elke patiënt. Ik ben er trots op het vak van je te hebben geleerd.

Er zijn vele arts-assistenten die gedurende de opleidingstijd mijn pad kruisten. Twee daarvan wil ik in het bijzonder noemen. Dick-Johan van Spronsen, beste DJ, ondanks dat jij na je opleidingstijd in Eindhoven naar het Hoge Noorden verdween, zijn wij altijd contact blijven houden. Ik was als assistent jaloers op jouw parate kennis en weet zeker dat je een voortreffelijke hematoloog en oncoloog bent geworden. Ik ben blij dat je uiteindelijk een prachtige plek hebt gevonden in Nijmegen. Ik had de eer paranimf te zijn bij jouw promotie. Ik vind het ook bijzonder dat jij diezelfde functie nu bij mijn promotie wilt bekleden. Charles Beerenhout, beste Charles, ook onze paden blijven elkaar kruisen. Je bent ooit begonnen als arts-assistent in het voormalige Diaconessenziekenhuis, thans Máxima Medisch Centrum, in Eindhoven, mijn huidige ziekenhuis. Daarna hebben we jarenlang samen de opleiding gedaan in het 
Catharina Ziekenhuis in Eindhoven en in het academisch ziekenhuis Maastricht. Vijf jaar lang reden we samen dagelijks op en neer, waarbij we lekker konden mopperen op alles dat niet goed ging. Gelukkig ging er ook veel wel goed, waardoor we nu beiden gepromoveerd zijn en als het goed is binnenkort zelfs bij elkaar in de maatschap komen. Beiden hebben we in die periode een gezin gesticht met drie spruiten. Samen hebben we namens de regio Maastricht in het bestuur gezeten van de JNIV. Samen zitten we nu in het dagelijks bestuur van de toekomstige fusiemaatschap. Je bent zeer consciëntieus en betrouwbaar, hetgeen ik bewonder, en ik hoop dat we tot in lengte van jaren op deze wijze kunnen blijven samenwerken.

Zonder steun van familie en gezin is een dergelijk proefschrift niet te schrijven. Mijn ouders hebben het mogelijk gemaakt dat ik mijn eigen weg kon gaan en als eerste in de familie geneeskunde ging studeren. Ik weet van anderen dat mijn vader trots was dat zijn zonen, anders dan hijzelf, beiden een universitaire opleiding konden voltooien. Helaas heeft hij het verdedigen van dit proefschrift niet meer mee mogen maken. $\mathrm{Na}$ een eerdere longembolie in de jaren negentig, waarbij ik altijd bang was dat dit het voorteken zou zijn van een ernstiger ziekte, liet hij mij in april 2004 op het strand in Fuerteventura een zwelling onder zijn rechter oksel voelen. Het bleek een uitzaaiing van een melanoom. Op 14 augustus 2004 overleed hij. Dit proefschrift draag ik daarom op aan mijn vader. Ik hoop dat hij vanaf zijn gouden bord van boven mee kan genieten en ben blij dat mijn moeder het voltooien van dit proefschrift nog wel mee kan maken.

Mijn gezin heeft ernstig geleden onder het schrijven van dit proefschrift. Hoewel ik geprobeerd heb zoveel mogelijk te schrijven tussen 23.00 uur en 1.00 uur 's nachts, is het soms onontkoombaar kostbare gezinstijd op te offeren om op tijd stukken af te hebben. Tanya, Anthe, Taeke en Douwe, ik houd van jullie en beloof hierbij na vandaag weer alle tijd te hebben voor zaken die in het leven veel belangrijker zijn dan het schrijven van een proefschrift en het behalen van de doctorsgraad.

Last but not least, dit proefschrift zou niet geschreven zijn zonder alle patiënten en gezonde controles die zich (soms extra) hebben laten prikken ten behoeve van de wetenschap en ons onderzoek. Velen van de patiënten zijn niet meer onder ons. Ik wil hen postuum dank zeggen en dit werk deels ook aan hen opdragen.

Eindhoven, 3 november 2006 


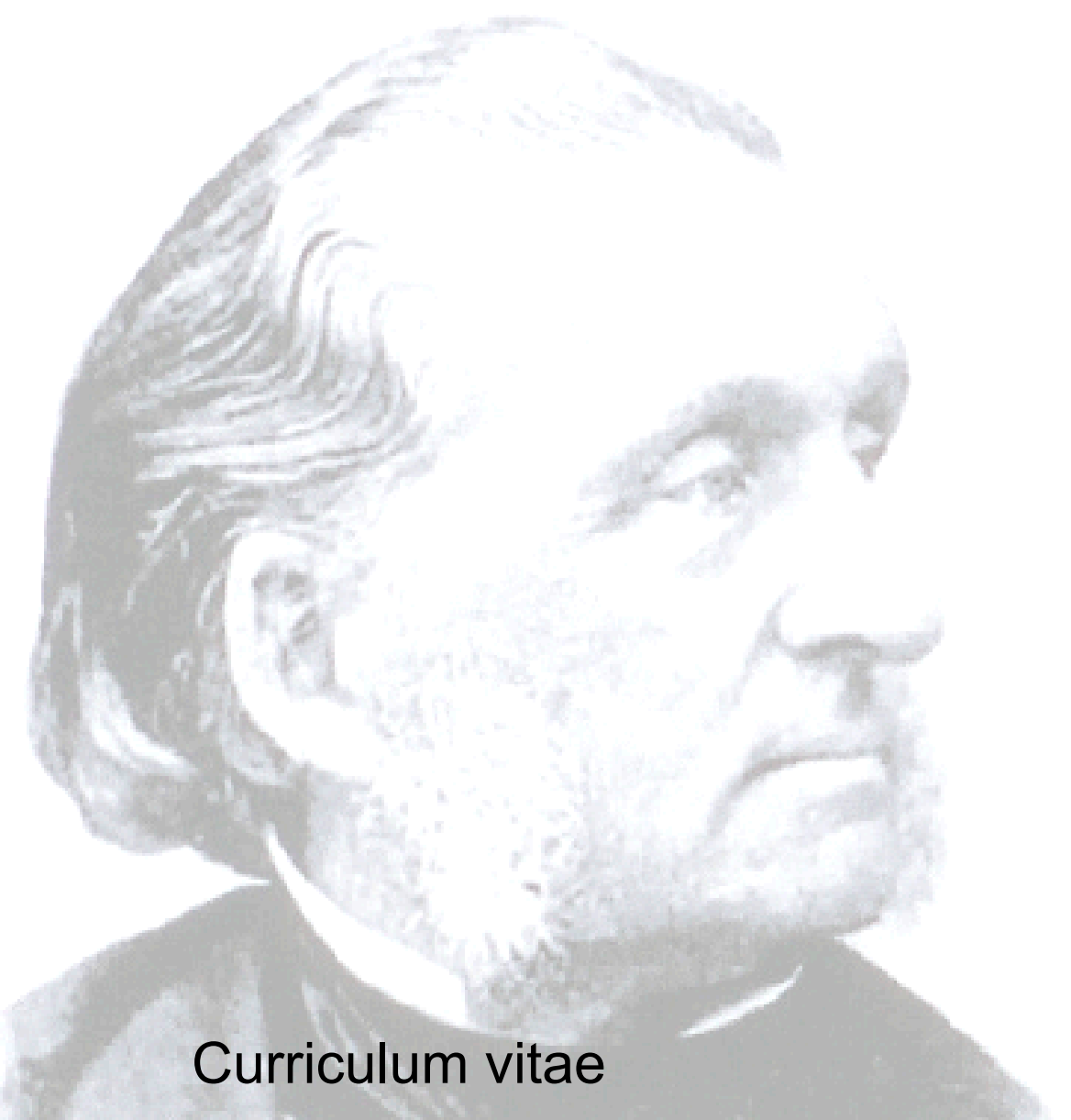




\section{Curriculum vitae}

Marten Ronald Nijziel werd op 29 april 1965 geboren in Amsterdam. In 1971 verhuisde het gezin Nijziel naar Maarssen, toen een klein dorpje nabij Utrecht. De lagere school werd doorlopen aan de Doornburgherschool in Maarssen (meester E.M. Lafleur). In 1977 volgde de overstap naar het Thorbecke Lyceum in Utrecht, alwaar in 1983 het diploma Gymnasium $\beta$ werd behaald. De studie geneeskunde werd gevolgd aan de Faculteit der Geneeskunde van de (Rijks) Universiteit Utrecht van 1983 tot 1992. Daarna werd de militaire dienstplicht vervuld op het opleidingscentrum voor de militaire geneeskundige dienst (OCMGD) te Hollandsche Rading bij de Geneeskundige Instructie Groep (hoofd majoor G. Gort) en in het Nederlands Militair Hockeyteam. In oktober 1993 startte hij als assistent geneeskundige niet in opleiding in het Catharina Ziekenhuis in Eindhoven. Vanaf 1 oktober 1994 was hij arts-assistent in opleiding in hetzelfde Catharina Ziekenhuis (opleiders dr. H.F.P. Hillen, dr. W.P.M. Breed en dr. S.J. Hoorntje). Op 1 oktober 1997 volgde de overstap naar het academisch ziekenhuis Maastricht (opleider prof. dr. H.F.P. Hillen). Hier werd de opleiding via een AGIKO constructie voortgezet, waarbij de opleiding deels werd ingericht om promotieonderzoek te doen naar de relatie tussen stolling en kanker. In zijn assistententijd was hij gedurende ruim 5 jaar lid van het bestuur van de juniorafdeling van de Nederlandsche Internisten Vereeniging en in die hoedanigheid van 1999 tot 2002 lid van het Concilium Medicinae Internae. Op 1 oktober 2002 werd de opleiding tot internist afgerond met registratie in het aandachtsgebied hematologie (opleider: prof. dr. H.C. Schouten). Vanaf 1 oktober 2002 is hij werkzaam als internist-hematoloog in het Máxima Medisch Centrum te Eindhoven/Veldhoven. Tevens is hij sindsdien hoofd van de zorg voor volwassenen met bloederziekten van het Hemofilie Behandel Centrum Eindhoven. Hij is sinds 3 oktober 1998 getrouwd met Tanya Kreeftenberg. Samen hebben zij 1 dochter, Anthe (2000), en 2 zonen, Taeke (2001) en Douwe (2004). 